\title{
Photovoltaic Industry \\ Progress through 1984
}
R. L. Watts
S. A. Smith
J. A. Dirks

April 1985

Prepared for the U.S. Department of Energy under Contract DE-ACO6-76RLO 1830

Pacific Northwest Laboratory Operated for the U.S. Department of Energy by Battelle Memorial Institute 


\title{
DISCLAIMER
}

This report was prepared as an account of work sponsored by an agency of the United States Government. Neither the United States Government nor any agency thereof, nor any of their employees, makes any warranty, express or implied, or assumes any legal liability or responsibility for the accuracy, completeness, or usefulness of any information, apparatus, product, or process disclosed, or represents that its use would not infringe privately owned rights. Reference herein to any specific commercial product, process, or service by trade name, trademark, manufacturer, or otherwise, does not necessarily constitute or imply its endorsement, recommendation, or favoring by the United States Government or any agency thereof. The views and opinions of authors expressed herein do not necessarily state or reflect those of the United States Government or any agency thereof.

\author{
PACIFIC NORTHWEST LABORATORY \\ operated by \\ BATTELLE \\ for the \\ UNITED STATES DEPARTMENT OF ENERGY \\ under Contract DE-AC06-76RLO 1830
}

\begin{tabular}{|c|c|}
\hline \multirow{2}{*}{\multicolumn{2}{|c|}{ Printed in the United States of America }} \\
\hline & \\
\hline \multicolumn{2}{|c|}{$\begin{array}{l}\text { Available from } \\
\text { National Technical Information Service }\end{array}$} \\
\hline \multicolumn{2}{|c|}{ United States Department of Commerce } \\
\hline \multicolumn{2}{|c|}{5285 Port Royal Road } \\
\hline \multicolumn{2}{|c|}{ Springfield, Virginia 22161} \\
\hline \multirow{2}{*}{\multicolumn{2}{|c|}{$\begin{array}{l}\text { NTIS Price Codes } \\
\text { Microfiche A01 }\end{array}$}} \\
\hline & \\
\hline \multicolumn{2}{|c|}{ Printed Copy } \\
\hline & \\
\hline Pages & Codes \\
\hline $001-025$ & A02 \\
\hline 026-050 & $\mathrm{A} 03$ \\
\hline 057-075 & A04 \\
\hline $076-100$ & A05 \\
\hline 101-125 & A06 \\
\hline $126-150$ & A07 \\
\hline $151-175$ & A08 \\
\hline $176-200$ & A09 \\
\hline $201-225$ & A010 \\
\hline $226-250$ & A011 \\
\hline $251-275$ & A012 \\
\hline $276-300$ & $\wedge 013$ \\
\hline
\end{tabular}


PHOTOVOLTAIC INDUSTRY

PROGRESS THROUGH 1984

R. L. Watts

S. A. Smith

J. A. Dirks

Apri1 1985

Prepared for the U.S. Department of Energy under Contract DE-AC06-76RLO 1830

Pacific Northwest Laboratory

Richland, Washington 99352 

The world photovoltaic (PV) industry continued to grow modestly during 1984 sparked by the increased use of amorphous silicon (A-Si) in consumer goods. Although single crystal silicon ( $\mathrm{Cz}$ ) continued to dominate the world market with $44 \%$, several factors indicate that the $\mathrm{Cz}$ technology is approaching maturity.

- Module prices stabilized at about $\$ 7 /$ watt for commercial quantity purchases.

- ARCO Solar extended a 10 year warranty on $\mathrm{Cz}$ modules.

o Flat plate $\mathrm{Cz}$ production about equaled the 1983 level.

- Major producers (Photowatt \& Solar Power Corp) completed their withdrawal from US production and Solenergy merged with Entropy Ltd. of Boulder, co.

- No production scale-up occurred or is planned for Cz facilities although modest reductions in production costs resulted from incremental improvements in cell efficiency and from process improvements.

- Spire Corporation has sold Cz manufacturing equipment to 17 foreign countries.

- Commercial R\&D emphasis shifted to other technologies such as amorphous silicon.

Single crystal production in 1985 is expected to equal to that of 1984 even though other technologies are chalienging its dominance.

Anorphous silicon production was $25 \%$ of the world market (about six megawatts) but was primarily confined to the specialty market such as watches and calculators. The Japanese clearly lead in the specialty market; however, the US may lead in the amorphous silicon power module market.

- ARCO Solar introduced the first A-Si power module with $5 \%$ efficiency.

- Chronar reported opening of their Port Jervis, NY facility.

- Energy Conversion Devices (ECD) built a cell production facility in Michigan and a module assembly plant in Ohio.

- Solarex was the first US manufacturer to sell A-Si to the Japanese. 
Overall the outlook for 1985 for A-Si is for substantial growth most of which will come from the specialty market. Power modules will be produced in modest quantities (100-200 kW) in 1985 in the US, and larger quantities should be expected in 1986 as confidence in their performance grows.

Semicrystalline flat plate modules constituted another $17 \%$ of total shipments (over $20 \%$ of power modules). There are several indications of vigor in the semicrystalline market:

o Solarex introduced a nominal power guarantee for their modules.

- Solavolt International is using semicrystalline cells because its characteristics are similar to that produced by their new ribbon process in finished modules.

- Solec International now offers both single and semicrystalline cells.

o Kyocera of Japan is agressively marketing semicrystalline modules in the US.

Modest growth of the semicrystalline market is expected in 1985 .

In 1984 the concentrator market share was only 13\%, much 10wer than 1983 expectations. A primary factor in the slow growth of concentrators may havebeen the legal questions reported to have been raised over some third party arrangements by the IRS. It is not expected that any major commercial markets will develop for concentrators in 1985. Ribbon production was less than $1 \%$ of the market and wit1 probably remain so in 1985.

China has indicated serious interest in exploiting the potential for PV to supply its remote electricity needs through domestic manufacture of PV electric systems.

On a regional basis, the US continued to be the world leader in PV with $50 \%$ of the market. However, Japanese production of PV grew by $45 \%$ in 1984 , and if this production growth rate continues, Japan will become the world leader by the end of 1985 . 
Summary and Forecast......................... i $i$

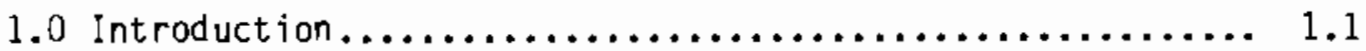

2.0 World Photovoltaics Industry.................. 2.1

2.1 U.S. PV Industry........................ 2.1

2.2 European PV Industry...................... 2.13

2.3 Japanese PV Industry.......................... 2.16

2.4 "Other" PV Region.......................... 2.19

3.0 Government Support of Photovoltaics............... 3.1

3.1 Direct Federal Purchases.................... 3.1

3.1 .1 U.S. Government Spending............... 3.2

3.1 .2 European Funding $\ldots \ldots \ldots \ldots \ldots \ldots \ldots \ldots \ldots \ldots . .3$

3.1.3 Japanese Funding................... 3.4

3.2 Indirect Federal Support................. 3.6

4.0 Market Sector Comparisons..................... 4.1

4.1 Customer Market Sectors..................... 4.2

4.2 End-Use Market Sectors.................... 4.4 


\section{FIGURES}

$2.1 \quad$ World PV Shipments..................................... 2.3

2.2 World PV Revenues.................................... 2.3

$2.3 \quad$ U.S. PV Shipments................................... 2.4

2.4 Subsidi zed and Nonsubsi di zed U.S. Shipments.............. 2.5

2.5 World Market Share.................................. 2.6

2.6 European PV Shipments............................... 2.15

2.7 Japanese PV Shi pments.............................. 2.18

3.1 Anual FPUP PV Purchases................................

3.2 Federal, Non FPUP PV Purchases......................... 3.2

Effective (after tax) Cost per Watt for
Residential PV Systems..................................

3.4 Dollar Value of Tax Credits (Residential)................ 3.8

3.5 Effect of Module Cost Reductions (Residential)............. 3.9

3.6 Effective Cost Per Watt (Non-Resi dential)................ 3.10

3.7 Tax Incentives for Non-Residential Systems................ 3.10

4.1 Customer Maket Sectors............................. 4.3

4.2 End-Use Market Sectors.............................. 4.5

4.3 Technology Share $(8 \mathrm{Mw}), \ldots \ldots \ldots \ldots \ldots \ldots \ldots \ldots \ldots \ldots \ldots \ldots \ldots, 4.7$ 
2.1 World PV Shipments $\ldots \ldots \ldots \ldots \ldots \ldots \ldots \ldots \ldots \ldots \ldots \ldots \ldots, 2.1$

2.2 Sumary of World PV Shipments According to Strategies Unl imited.............................. 2.2

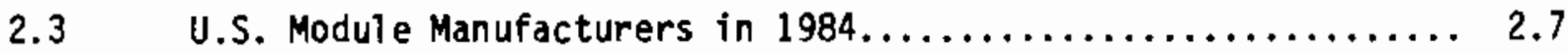

2.4 Major European Module Manufacturers in $1984 \ldots \ldots \ldots \ldots \ldots \ldots 2.13$

2.5 Major Japanese Module Manufacturers in $1984 \ldots \ldots \ldots \ldots \ldots .2 .17$

3.1 Operating European Pilot Plants........................ 3.4

3.2 Sunshine Project vs. U.S. PV Funding.................... 3.5

4.1 Shi pments to Customer Market Sectors.................... 4.4

4.2 Shipments to End-Use Market Sectors.................... 4.6

4.3 PV Manufacturers Using Cz Technology in $1984 \ldots \ldots \ldots \ldots \ldots .4 .6$

4.4 PV Companies Developing A-Si Technology in $1984 \ldots \ldots \ldots \ldots \ldots 4.8$

4.5 Major PV Manufacturers Using Semix Technology in $1984 \ldots \ldots \ldots \ldots \ldots \ldots \ldots \ldots \ldots \ldots \ldots \ldots \ldots \ldots \ldots \ldots \ldots \ldots \ldots \ldots, 4.8$

4.6 Major PV Manufacturers Using Concentrator Technology in $1984 \ldots \ldots \ldots \ldots \ldots \ldots \ldots \ldots \ldots \ldots \ldots \ldots \ldots, 4.9$ 


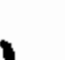




\subsection{INTROOUCTION}

The growth of the U.S. photovoltaics (PV) industry over the past decade has been impressive. First designed to provide power for satellites using highcost production techniques, $P V$ is now the economical choice in many remote terrestrial applications. The remarkable growth of PV in terms of quality of cells and modules, production techniques, and system design, was initiated by a cooperative effort of the U.S. Government and the domestic PV manufacturers.

European and Japanese firms entered the PV industry later, but are also growing rapidy. The Europeans continue to supply PV systems for village electrification and water pumping to many Third World countries. The Japanese have been developing the amorphous silicon (A-Si) technology by expanding its use in consumer goods. The world PV industry saw dramatic changes in industry ownership and in the emphasis on developing new and improved technology during 1984.

The objective of this report is to present information on the developments of the worid PV industry and focuses on developments occurring in 1984. Information is presented on a regional basis (U.S., Europe, Japan, other) to avoid disclosing company-confidential data. All information was gleaned from several sources, including a review of the technical literature and direct contacts with PV manufacturers. Prior to publishing the regional totals, all numbers were compared with those of other sources.

The information contained in this report is prepared for use by the Department of Energy for their use in long-term R\&D planning. However, this information should also be of interest to PV manufacturers and to those who may be contemplating entering the PV market.

This report is divided into five chapters: Chapter 2.0 sumnarizes PV shipments for 1984, Chapter 3.0 presents information on government support of PV, and Chapter 4.0 describes the various PV market sectors. Appendix A lists the major PV events for 1984. 


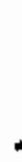




\subsection{WORLD PHOTOVOLTAICS INDUSTRY}

In 1984 the world photovoltaic (PV) industry continued to grow, with shipments of PV modules and cells increasing from $21.5 \mathrm{MW}$ in 1983 to $23.2 \mathrm{MW}$ (see Table 2.1 and Figure 2.1). This represents an increase in revenues from module sales of $\$ 200$ million in 1983 to $\$ 250$ million in 1984 (all in constant 1984 dollars). Revenue to al 1 sectors of the PV industry (includes revenues to systems houses, dealers, distributors and 805 suppliers) increased from $\$ 365$ million in 1983 to $\$ 394$ million in 1984 (figure 2.2). The primary reason for the increase in revenues was the growth of PV usage in consumer goods. The most significant increase in PV shipments during 1984 was made by the Japanese. U.S. shipments fell by $7 \%$ and European PV shipments remained unchanged.

For many firms, the market growth and technology development of PV did not meet expectations for 1984 . Czochralski (Cz) cell cost reductions were not as significant as they had been in previous years. The following sections provide information on PV shipments and the major firms within the industry on a regional basis.

Table 2.1. Worid PV Shipments

\begin{tabular}{|c|c|c|c|c|c|c|}
\hline \multirow[b]{2}{*}{ Region } & \multicolumn{5}{|c|}{ Shipments } & \multirow{2}{*}{$\begin{array}{c}\text { Percent } \\
\text { Change From } \\
1983-1984\end{array}$} \\
\hline & $\overline{1980}$ & 1981 & 1982 & 1983 & $\overline{1984}$ & \\
\hline US Flate Plate & 2.5 & 2.9 & 4.4 & 9.7 & 8.6 & \\
\hline US Conc. & .0 & .6 & .5 & 2.8 & 3.0 & \\
\hline Total US & 2.5 & 3.5 & 4.9 & 12.5 & 11.6 & -7 \\
\hline Europe & .4 & .9 & 1.7 & 3.3 & 3.3 & 0 \\
\hline Japan & .5 & 1.1 & 1.7 & 5.3 & 7.7 & 45 \\
\hline & .1 & & .1 & .4 & & 33 \\
\hline TTAL & $\overline{3.4}$ & 5.5 & 8.4 & 21.5 & $23 . \overline{2}$ & \\
\hline
\end{tabular}

\subsection{U.S. PV INDUSTRY}

Since 1980 the U.S. has dominated the world PV industry. PNL estimates that the shipments of PV by U.S. manufacturers have grown from $2.5 \mathrm{MW}$ in 1980 to $11.6 \mathrm{MW}$ in 1984 (Figure 2.3). 
Table 2.2. Summary of World PV Shipments According to

Strategies Unlimited

Region $\quad 1983$ Shipments (MW) $\quad 1984$ Shipments (MW)

$\begin{array}{lll}\text { US } & 9.3 & 8.5 \\ \text { Japan } & 3.8 & 6.6 \\ \text { Europe } & 2.2 & 2.6 \\ \text { Other } & \underline{0.3} & \underline{0.8} \\ \text { Total } & 15.6 & 18.5\end{array}$

Source: Best, D. 1985. "Profiling 1984's World Market". Solar Age April, 1985. pp. 22-23.

Other estimates of world PV shipments are available from a variety of sources. Estimates of world PV shipments for 1983 and 1984 by Strategies Unlimited are presented in Table 2.2. For both 1983 and 1984 the estimates provided by Strategies Unilimited are lower than the PNL estimates. The primary reason for these differences is in the accounting of augmented PV systems, and in estimating the amount of PV in consumer goods.

Although U.S. shipments declined from 1983 to 1984, the U.S. continues to be the leader in PV technology, and was the first to introduce A-Si modules to the comercial power module market. The rapid expansion of the U.S. industry primarily reflects the growth of two companies: ARCO Solar and United Energy Corporation (UEC).

ARCO Solar continued to be the world leader in PV manufacturing in 1984 serving a variety of commercial markets. A substantial portion of their production was installed at the utility-scale Cariso Plains installation and at Sacramento Municipal Utility District. The Cariso Plains project currently has an installed capacity of $6.5 \mathrm{MW}$ and couid ultimately have a capacity of up to $16.5 \mathrm{MH}$. The power produced is being sold to Pacific Gas and Electric.

UEC continued during eariy 1984 to market its PV/solar themal generator concentrator that is capabie of producing $2.5 \mathrm{kWh}$ and 40,000 Btus of hot water per hour. The majority of UEC sales have been financed through third-party arrangements. 


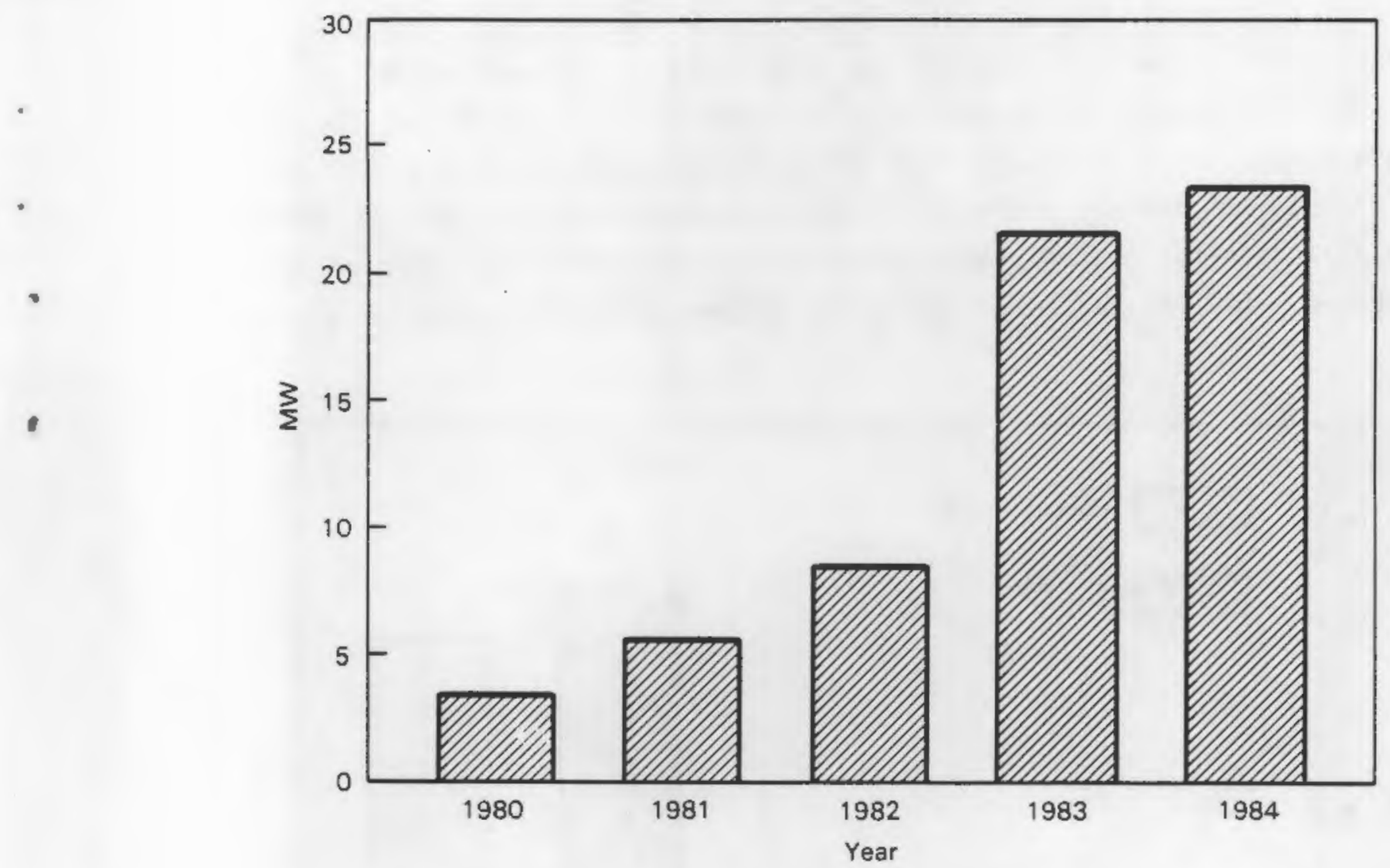

Figure 2.1 World PV Shipments

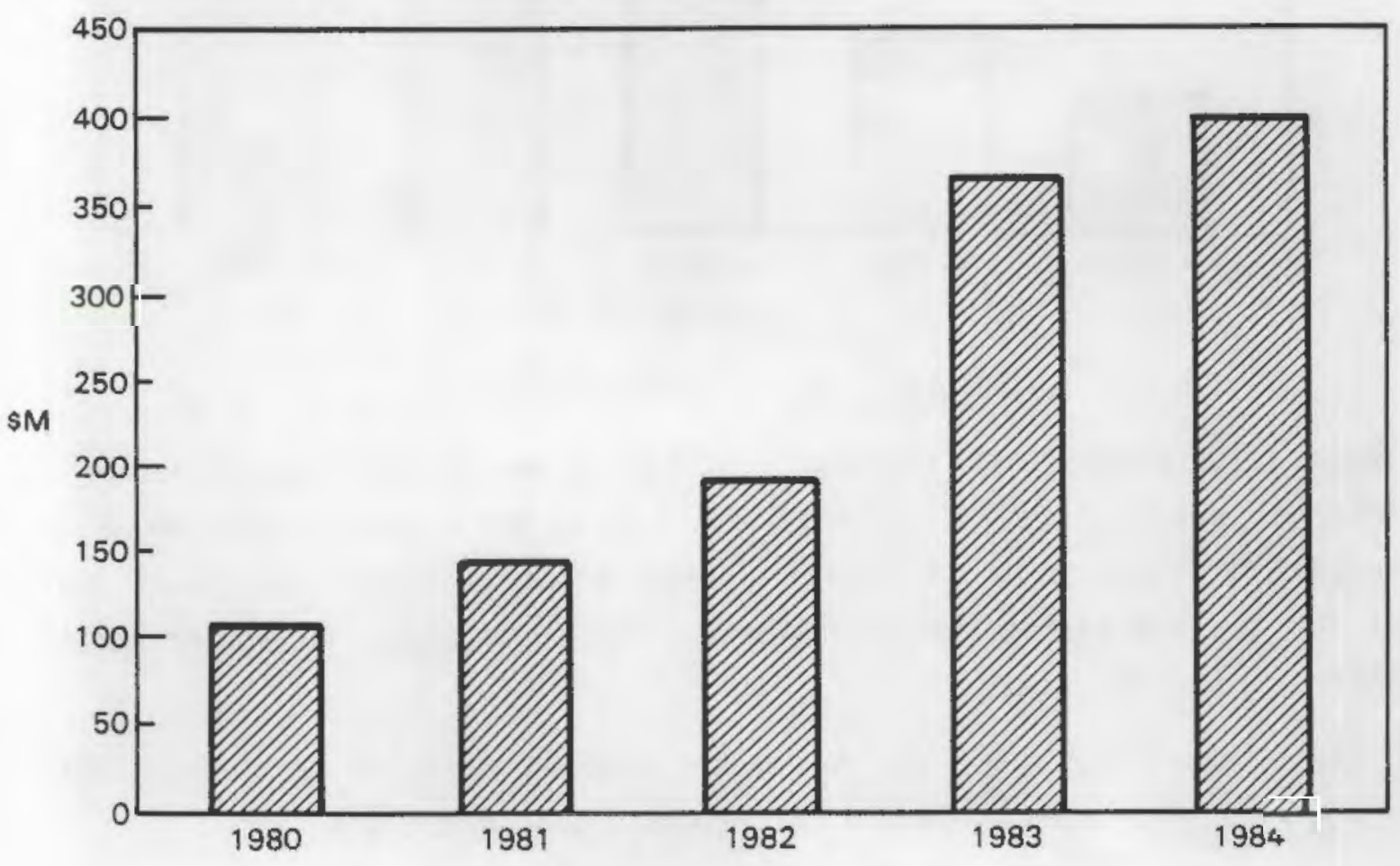

Figure 2.2 World PV Revenues 
During 1983 the U.S. market was stimulated by a combination of direct government purchases and those heavily dependent on financial incentives (figure 2.4). It is estimated that these shipments amounted to $8.5 \mathrm{MW}$ in 1983 (70\% of U.S. shipments). This MW estimate is conservative since it does not include residential systems whose purchase may have been dependent on the tax incentives. In 1984 Federally subsidized shipments had decreased to about 5.5 MN.

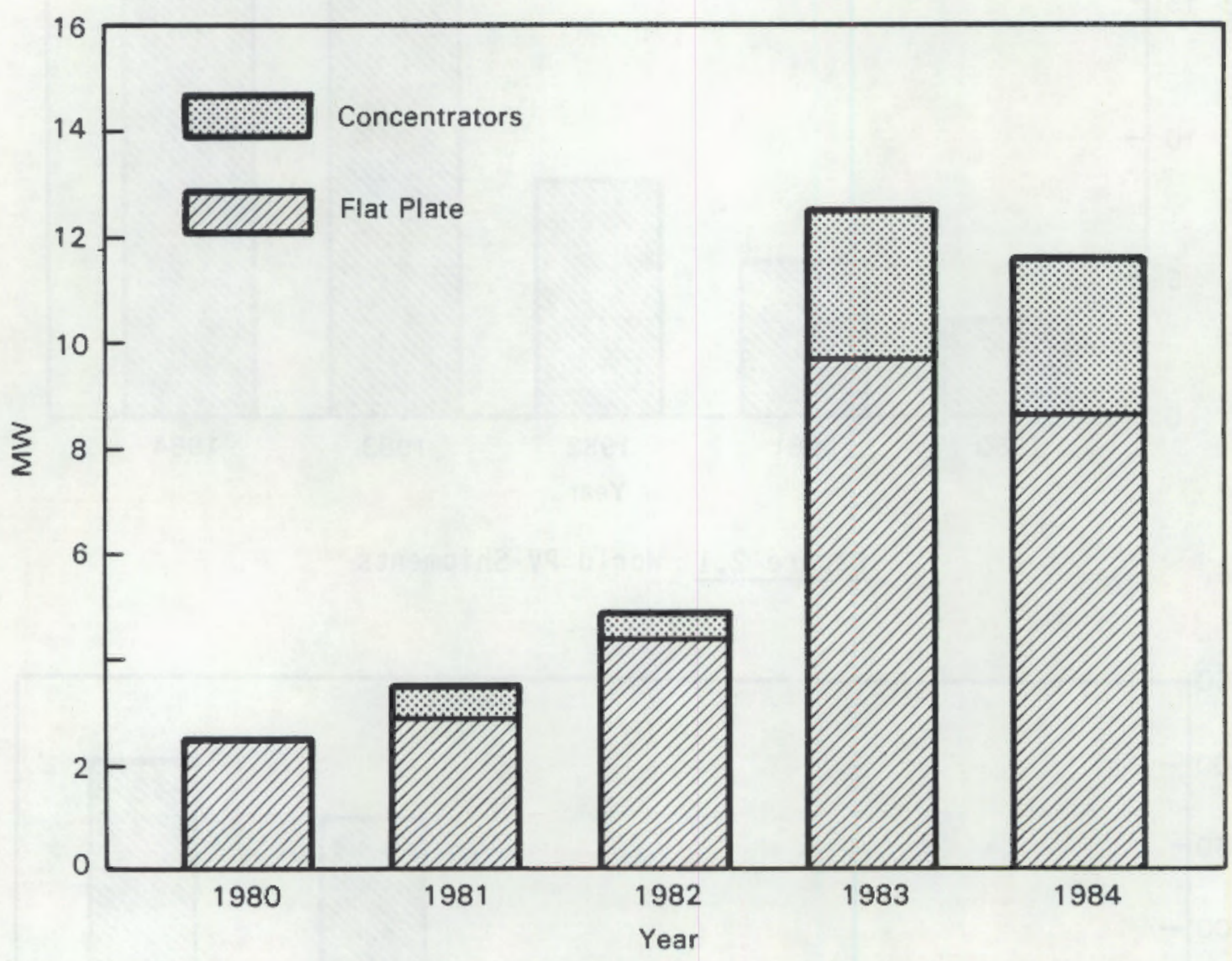

\section{Figure 2.3 U.S. PV Shipments}

There were substantial increases in the domestic and export market for conventional stand alone PV applications. These sales increased from about 4 MW in 1983 to about $6 \mathrm{MW}$ in 1984. These increases would have been larger except for the continuing strong dollar and the continuing shortage of money in the international markets.

Overa11, the U.S. share of the market dropped from $58 \%$ in 1983 to $50 \%$ in 1984 (figure 2.5) primarily due to the decrease subsidized shipments. 
During the early 1980s, module prices for large government purchases were in the range of $\$ 10-\$ 12 / W p$. By 1983 module prices had fallen to about $\$ 5.00 / \mathrm{Wp}$, with the SMUD II bids. During 1984 , price competition was moderate at the retail level.

Unfortunately $\mathrm{Cz}$ production costs have not declined sufficiently during the last two years to provide adequate profits to module manufacturers. Unprofitable operations forced several firms to reorganize their ownership arrangements including:

- Photowatt - left the PV business in 1983

- Solar Power Corp. - left the business early in 1984

- Solarex - purchased by Standard $0 i 1$ of Indiana (AMOCO) in 1983 (Solarex name continued)

- Applied Solar Energy Corp - in 1982 shifted emphasis from terrestial to space

- E-System - sold its PV division to its employees, who renamed the company ENTECH in 1983

0 Martin-Marietta - left the PV industry in 1984

- Solarex - layed off 100 employees in 1984

- ARCO - layed off about 140 employees in 1984.

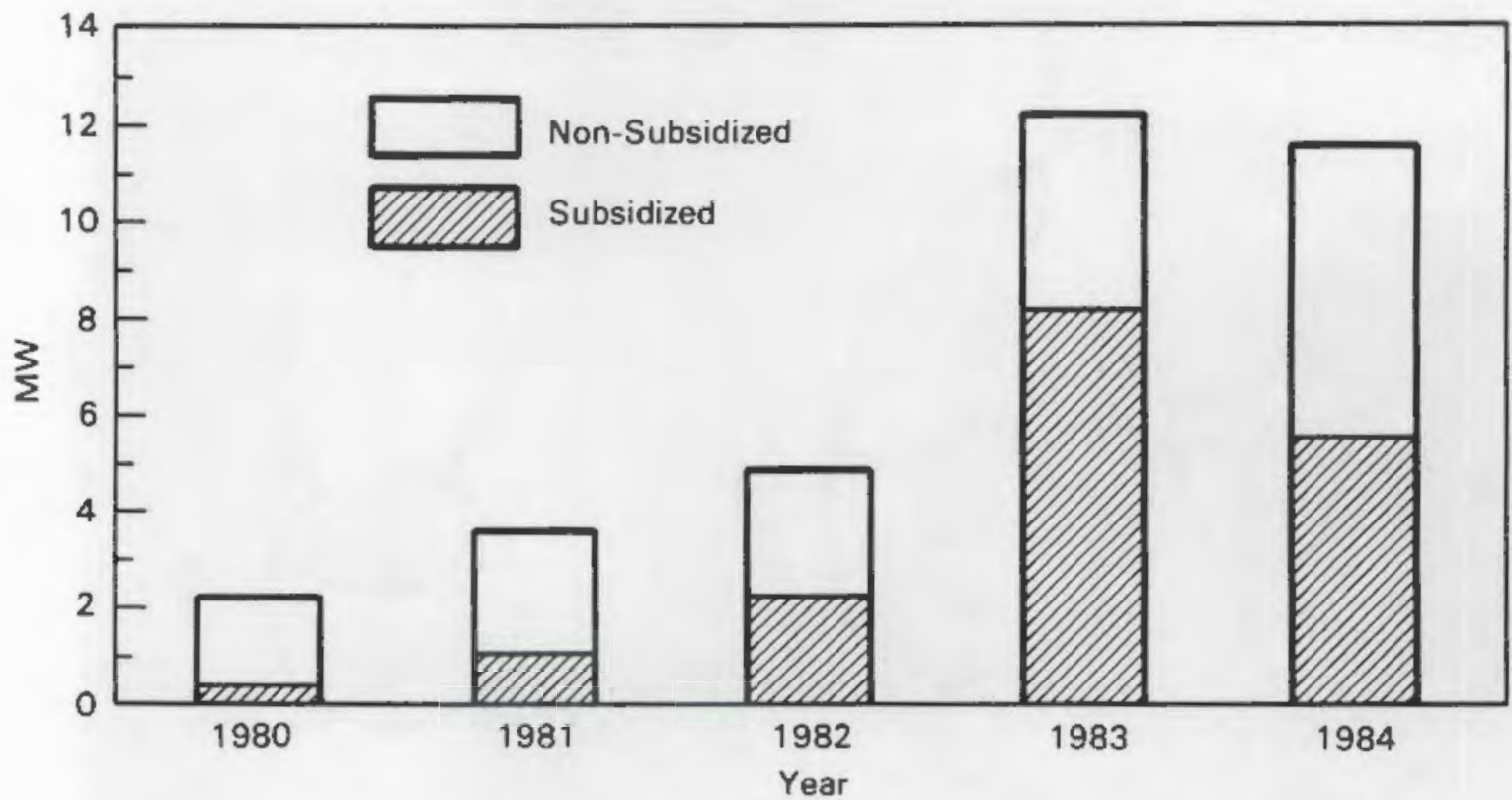

Figure 2.4 Subsidized and Nonsubsidized U.S. Shipments

Table 2.3 lists PV module manufacturers in the U.S. during 1984 . The following section provides background information on U.S. manufacturers. 

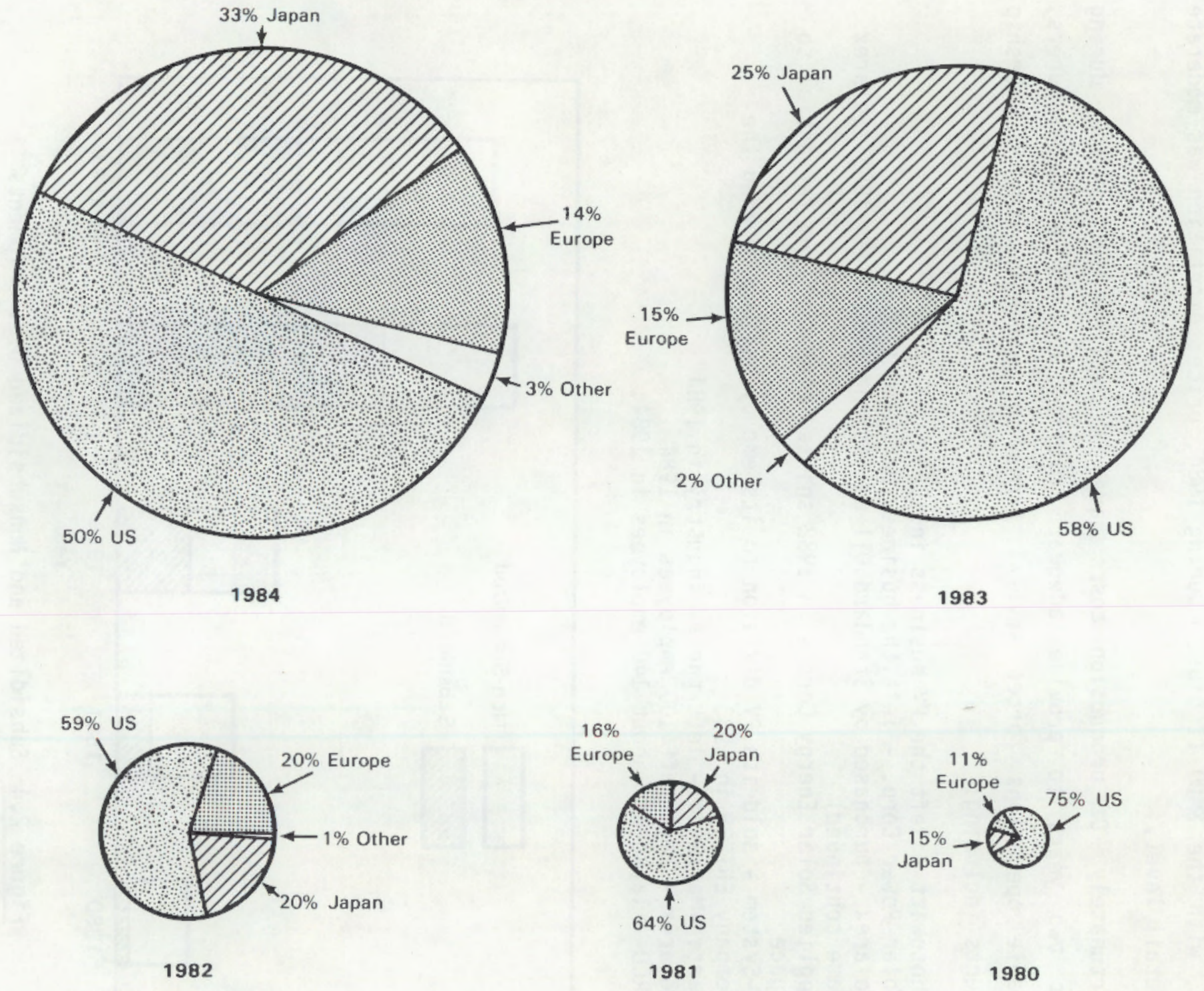
TABLE 2.3. U.S. Module Manufacturers in 1984

\author{
ARCO Solar \\ Applied Solar Energy Corp. \\ Chronar \\ Entech \\ Free Energy Systems \\ Intersol \\ Martin-Marietta Aerospace \\ Mobil Solar Energy \\ Photowatt International
}

Silicon Sensors

Solar Power Corporation

Solarex Corporation

Solavolt International

Solenergy

Solec International

Tideland Signal

United Energy Corporation

ARCO Solar, Inc. This company is a wholly owned subsidiary of ARCO Solar Industries, which is a subsidiary of the Atlantic Richfield Company. In 1978, ARCO Solar, Inc., purchased a small photovoltaic manufacturer, Solar Technology International, which had been founded three years earlier. ARCO proceeded to install a modern, automated assembly line to produce silicon cells and modules.

In January 1980, the Atlantic Richfield Company signed a multi-million doliar product development and licensing agreement with Energy Conversion Devices, Inc. (ECD), aimed at accelerating the commercialization of ECD's amorphous devices. In May 1981, ARCO decided to let the ECD PV contract expire and decided to support its own amorphous silicon R\&0.

During 1983 ARCO built the first 1 MW central station PV system in Hesperia, California and announced plans for a 16 MW PV facility at Carissa Plains. In 1984 ARCO introduced the world's first commercial A-Si power module, the "Genesis". This module is $5 \%$ efficient and carries a 1 year warranty. ARCO aiso increased the warranty on many of its single crystal Si power modules to 10 years, and received the Underwriter's Laboratory approval on its M53 and M73 modules. ARCO layed-off about 140 of their 600 employees during 1984; however, most lay-offs were in non-research areas.

Chronar Corporation This company was incorporated in 1976 with the purpose of developing comercial PV manufacturing facilities. To date, Chronar has developed a batch process for producing A-Si cells and modules. PV production equipment has been sold to several organizations through joint venture agreements with Chronar. 
- AFG Industries - In 1983 signed an agreement to install a 1 MW production line in Tennessee. Chronar retained $51 \%$ ownership and AFG $49 \%$. Financing for the sale came from $\$ 5$ million in industrial revenue bonds.

- Port Jervis, NY - Chronar and a group of private investors joined together to establish a batch processing facility. This $\$ 6$ million installation was opened in December, 1984.

- Alabama Power - Signed an agreement in March 1984 to build a batch processing facility. Alabama power will pay $\$ 6.1$ million for $85 \%$ ownership in the joint venture, and Chronar will pay $\$ 1.1$ million for a $15 \%$ ownership share.

o Chronar Ltd., Bridgend Wales - This wholly owned subsidiary was financed through grants and low interest loans from wales. The $1 \mathrm{MW}$ facility opened April 17, 1985 and will operate 3 shifts by the Fall of 1985 .

- Chronar France - This plant is owned by Chronar, SOMDIAA, Charbonnages de France, and Groupe Drout. The $\$ 10$ million, 1 MW facility will cone online by late 1985 .

During 1984 Chronar acquired Tri Solar Corporation, a PV-powered pump manufacturer. In December Chronar opened the Port jervis facility.

Chronar's stock is sold through the over-the-counter market and is reported in the NASDAQ exchange under the symbol CRNR. The closing bids for Chronar stock during 1984 went from a low of $\$ 6.50 /$ share to a high of $\$ 21.25 /$ share. currently, the stock has a market value of $\$ 9.25 /$ share $(3 / 1 / 85)$.

Chronar currently has 140 employees in the US and 25 employees in the UK.

Energy Conversion Devices (ECD) This company was estabiished in 1960 and has developed a continuous roll production technique to produce A-Si cells. The development of this technique was partially funded by $\$ 9.3$ million received from ARCO in 1980. This technology was incorporated into the production equipment that was sold to a Sharp/ECD joint venture of Japan.

ECO has established two partnership agreements with Standard 0il of Ohio (1981): technology partnership and an operating partnership, Sovonics Solar Systems. The purposes of these agreements is to perform further research on the production of PV cells, to commercialize the PV technology and to grant royalty-bearing leases. Since 1981 SOHIO has contributed $\$ 44$ million to ECD through their operating partnership. 
During 1984 Sovonics Solar Systems announced its plans to build a cell production facility in Michigan and a module assembly plant in Ohio. Sovonics also signed a memorandum of understanding with China to establish a joint venture to manufacture and market A-Si.

ECD stock is traded on the over-the-counter market under the symbol ENER. The closing bids for ECO stock during 1984 went from a low of $\$ 20.88$ /share to a high of $\$ 42.00 /$ share. Currently, the stock has a market value of $\$ 27.50 /$ share $(3 / 1 / 85)$. ECD currently employs 459 fuli time employees with approximately 100 on PV.

Mobil Solar Energy Corporation This was originally a joint venture formed in 1974 by Tyco Laboratories, Inc. (20\%), and Mobil 0il Corporation (80\%). In 1983 Mobil purchased Tyco Labs' interest in the company and the company was renamed Mobil Solar Energy Corp. After several years of research and development, Mobil has opened a new manufacturing facility as a part of a major expansion plan to produce $10 \mathrm{MW}$ per year within the next few years. In 1983 Mobil introduced a new ribbon technology called the nonagon. This technique produces a nine-sided tube of $\mathrm{Si}$ that is cut by a laser to produce rectangular cells. During the past year Mobil was awarded a $\$ 245,000$ contract to supply 37 $\mathrm{kW}$ of ribbon silicon modules for Phase II of the SMUD project. The parent organization, Mobil Corporation, was incorporated in 1882 and is a major energy company ( $\$ 60$ billion in sales in 1984 ), with products and services in oil, gas, chemicals, and paperboard.

Photowatt International Photowatt first entered the PV industry in 1974 as the PV division of Sensor Technology of Chatsworth, California. In 1979, Sensor Technology moved their operations to Phoenix, Arizona and Photowatt International was formed. Sensor Technology retained ownership of one-half of the new company and GESA of France controlled the other half. GESA subsequently started Photowatt SA in France and Photowatt Afrique.

In 1983 Photowatt sold its PV inventory and left the industry. 
Solec International, Inc. This company was started by Ishaq Shahrayar with the purpose of manufacturing PV cells and modules. In 1980, pilkington Brothers, a British glass manufacturer, purchased $80 \%$ interest in Solec. This acquisition proved to be quite beneficial to solec since it provided the company with worldwide sales outlets and Solec's sales increased by $300 \%$.

Currently, Solec purchases wafers and manufactures cells and panels. The company intends to establish module assembly plants overseas while continuing to manufacture celis in the U.S. Solec employes about 50 people.

Solenergy Corporation. This is a small, privately held business established in 1978 by Robert Willis to manufacture PV devices. Solenergy purchases silicon slices, produces a wide variety of products, and has a staff of 25 people. Kayex Corporation is a $20 \%$ shareholder in the company and has annual sales of about $\$ 20$ million. Kayex is a General Signal Corporation company specializing in material processing equipment for the PV and silicon industries. In 1983 Solenergy merged with Entropy, Ltd. via a stock exchange, and in 1984 they signed a letter of intent with China to build a PV manufacturing plant.

Spire Corporation. Founded in 1969 as a small business, this high technology company is engaged in research, engineering, and manufacturing of PV cells and processing equipment for high-volume production of cells and modules. The company has produced cells and modules for the DOE program, but its primary interest is manufacturing PV production equipment. The company is also developing thin film processes for low-cost substrate fabrication, thin film deposition, and cell structure formation. In 1983 Spire began to sell its SPI-LINE ${ }^{T M}$ system to Saudia Arabia and to India. They also developed a process for depositing GaAs directly onto a silicon substrate. This process may significantly reduce the cost of GaAs cells. Spire signed a $\$ 4$ million agreement with China in 1984 to sell $1 \mathrm{MW}$ of $\mathrm{PV}$ manufacturing equipment. Spire sold a $1 \mathrm{MW}$ PV module manufacturing system to Solarpac of Canada.

Spire Corporation stock is traded on the NASDAQ exchange under the symbol SPIR. The closing bids for spire stock went from a low of $\$ 8.50$ /share to a high of $\$ 14.50 /$ share in 1984. Currently the stock has a market value of $\$ 15.25$ /share $(3 / 1 / 85)$. 
Solar Power Corporation. Established in 1969 as a small business, Solar Power Corporation was acquired by Exxon in 1975. In 1983 the company reduced the size of its production facility and distribution channels and organized to operate with less than 100 employees. Solar Power concentrated on manufacturing PV devices for today's market. Advanced R\&D was conducted in other areas of the parent company. Solar Power Corporation provided the PV system at the Universe of Energy Pavilion at Disney World. Exxon Corporation, with $\$ 103$ billion in sales (1980), is a major multi-national integrated company in the areas of oil and gas, energy, information systems, and chemicals. The company supported considerable internal research in advanced PV materials, with particular emphasis on amorphous silicon.

In 1983, Exxon announced that Solar Power Corporation was for sale. In 1984 Solar Power Corporation's inventories were sold to Solarex and its employees layed off. Exxon Corp. also closed Solar Power Corporation's amorphous silicon research program in Linden, Nu in 1983. To date, Solar Power Corporation has not been sold. Solarex is providing service to Solar Power corp. customers.

Solarex Corporation. Solarex Corporation entered the PV industry in 1973, and soon became known for its technological leadership with such developments as the most efficient solar cell, the first high density modules, vertical junction cells and the ultra light $2 \mathrm{mil}$ cell among others. The most significant development was the semicrystalline silicon material for solar cell use. Prior to this development single crystal silicon was the only material used for solar cell mass production. Solarex started a wholly owned subsidiary, Semix, to manufacture the senicrystalline material.

Until 1983 Solarex was a widely held company with corporate investors from such countries as Italy. Holland, and France. In 1983 Solarex became a totally owned subsidiary of Standard 0il Company (Indiana) and Semix became a division of Solarex Corporation. Solarex has a manufacturing facility in Australia (Solarex Pty) and one in Hong Kong (Solarex Electric) for its consumer products. It also has sales offices in Geneva, Switzerland and from coast to coast in the U.S. 
In 1983, Solarex acquired RCA's amorphous silicon technology now known as the Solarex Thin Film Division. Solarex Thin Film Division was the first U.S. Company to commercially ship amorphous products. Additionally, Solarex has an Aerospace division which manufactures solar cells for use on satellites and spacecraft and was recently chosen to supply the PV modules for NASA's COBE spacecraft. In 1984 Solarex introduced the industry's only minimum wattage guarantee for PV modules. Solarex has 600 employees.

Solavolt International. This company was fomed as a joint venture of Motorola (1984 sales of $\$ 5$ billion) and Shell 0i1 Co. Subsidiaries (1984 sales of $\$ 21$ billion) in 1981. Both companies had been working in PV since the mid 1970 's.

Solavolt originally had two divisions -- one to concentrate on thin film technologies and the second to develop their continuous ribbon production process. The thin film research was phased out in 1983. Currently they are using conventional and polycrystalline silicon technology to produce a limited number of high-quality modules. Production of these modules allows solavolt to gain both produciton and marketing experience. It is expected that solavolt will introduce their ribbon modules in the second half of 1985.

Solavolt currently has 175 employees.

Tideland Signal. Tideland has been supplying PV systems for powering offshore navigational aids since 1972. Tideland has developed and patented a very durable all-glass solar module. Cells for these modules are manufactured by Tideland Energy Pty., Ltd., a wholly owned subsidiary in Sydney, Australia. More than 12,000 Tideland Solaviva navigational aids have been installed world wide. Tideland also has wholly owned subsidiaries in Canada, Mexico, and the United kingdom.

United Energy Corp. UEC, a privately owned enterprise operated under the leadership of Ernest Lampert, originated in Hawaij in 1978. UEC began the manufacture and sale of PV panels and systems. In 1981 the company moved its primary operations to California where it became a diversified developer and manufacturer of renewable energy equipment systems. 
UEC markets a solar electrothermal generator equipped with Point Focus Fresnel Lenses and actively cooled PV concentrator cells. The generators are mounted on dual-axis tracking system rated at $2.5 \mathrm{~kW}$ and 33,000 btu per hour. 1984 sales of this product were reported to be approximately $\$ 45$ million which would place UEC second in the world ranking of PV manufacturers. The company had a staff of 1500 employees during its period of peak production.

UEC is vertically integrating its manufacturing operations. Manufacturing units are located in California (Foster City), Mexico (Mexicali) and India (Madras).

UEC has sponsored "The Solar Revolution" which is an educational program describing the many benefits of using renewable energy resources.

The majority of their sales have been financed through third party arrangements. Two of UEC's major sites in 1983-84 were Barstow and Borego Springs, California.

\subsection{EUROPEAN PV INDUSTRY}

Shipments of PV modules by European firms increased from $0.5 \mathrm{MW}$ in 1980 to approximately $3.3 \mathrm{MW}$ in 1984 (figure 2.6). However, there was no apparent growth in shipments between 1983 and 1984. A portion of this previous increase in shipments can be attributed to the assistance of the Commission of European Communities (CEC). The CEC has assisted European PV manufacturers in establishing 15 pilot projects under cost-sharing arrangements.

Table 2.4 lists the major European module manufacturers in 1984 . The following section provides background information on the major European module manuf acturers.

Table 2.4. Major European Module Manufacturers in 1984

$\begin{array}{ll}\text { Belgsolar } & \text { BP Solar } \\ \text { Energie Nouvelle } & \text { Andratica Componeti } \\ \text { France Photon } & \text { Ansaldo } \\ \text { Photowatt SA } & \text { Helios Technology } \\ \text { AEG Telefunken } & \text { Pragma } \\ \text { Siemens A.G. } & \text { Isophoton }\end{array}$


AEG Telefunken. AEG Telefunken has been involved in PV for the past 20 years and is currently Gemany's largest PV manufacturer. In the past, AEG purchased polycrystalline si from other manufacturers for their PV modules. However, $A E G$ has been working with Heliotronic, a Wacker Chemitronic subsidiary, on the development of low cost polycrystalline silicon.

Currently, AEG markets a wide range of PV systems such as hazard beacons, water pumping systems, and telecommunications relay stations. AEG was the primary contractor for the $300 \mathrm{~kW}$ Pellworm Island PV system that was partially funded by the CEC.

Ansaldo. Ansaldo is a state owned electromechanical company appointed by the government of Italy for the development and production of energy systems. They manufacture their ow single crystalline cells and produce PV modules. Currently, PV production capacity is about $200 \mathrm{kH}$. Some research is being conducted on A-Si; however, they have no plans to introudce A-Si modules in the near future.

Ansaldo has been involved in the construction of a $35 \mathrm{~kW}$ hybrid thermal/PV plant in Australia.

BP Solar. Prior to 1983, BP Solar was a joint venture between British Petroleum (BP) and Lucas. In 1983, BP purchased Lucas' interest in the company. Currently they purchase cells and produce modules. Their marketing objective is not to sell individual modules, but complete PV systems. In 1983 BP Solar began installing the largest PV system in the U.X. near Southampton. The $30 \mathrm{~kW}$ installation is estimated to cost $\$ 1.5 \mathrm{million}$ and is financed by $\mathrm{BP}$ Solar and the Department of Industry. During 1984 BP Solar acquired the film division of Monosolar as well as the technology to manufacture the mercury, cadmium, and tellurium cells.

France Photon. France Photon is a wholly owned subsidiary of Leroy-Somers, a medium sized electrical company with 4000 employees. The subsidiary was formed in 1978 with the purpose of producing single and polycrystalline cells and modules using the Solarex technology. The design and marketing of complete PV systems is performed by two other Leroy-Somers groups: Pompes Guinard and Systemes Solaires.

France Photon has built a $44 \mathrm{kw}$ village electric system at Rondolinu Cargese, Corsica. 


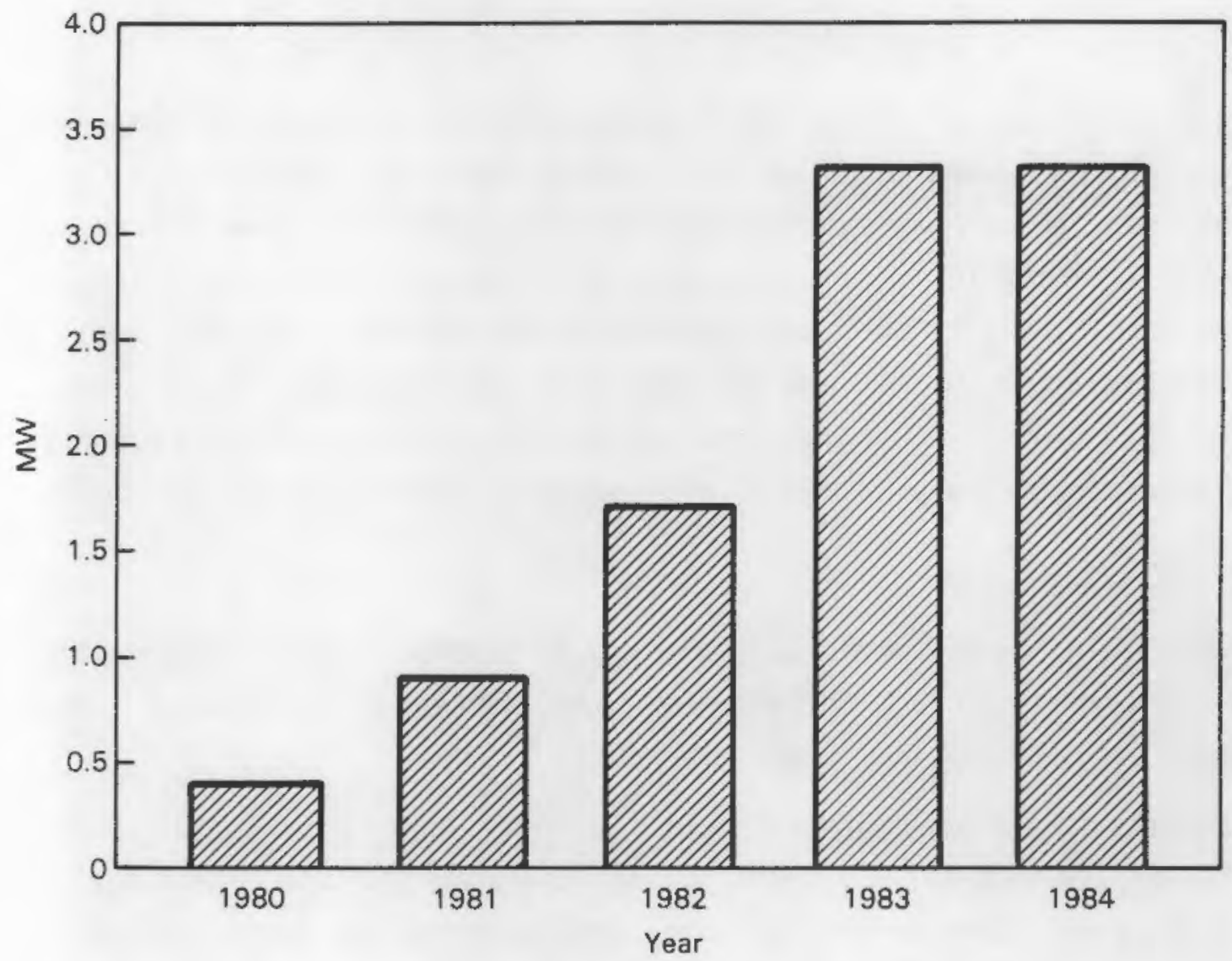

Figure 2.6 European PV Shipments

Helios. Helios is located in Italy and is one of the few non-oil, nongovernment funded module producers in Europe. Helios purchased it's PV technology from Solec International and has an advanced, low cost, automated cell and module manufacturing line. Their cell production process is unique in that wafers are etched until small tetrahedra are formed on the surface, thus reducing reflection and increasing efficiency.

Helios has been a major cell supplier for BP Solar, and they have concentrated their marketing efforts in southern Europe.

Photowatt, SA. This company is a subsidiary of SAFT (CGE group), ELF (a major oil company) and RTC (the Philips group) with its headquarters located in Revie - Malmaison, near Paris. Photowatt has also established a company, Photowatt Afrique, in Abidjan, Ivory Coast, to sell small PV powered systems to neighboring countries. In 1984 photowatt started steps toward commercialization of "polyx" ingot casting process developed by Photowatt and Laboratories de Marcousses. Photowatt will manufacture about 50\% of their modules in 1985 using Polyx multicrystalline si, and $100 \%$ of their modules in 1986 . By switching to the Polyx multicrystalline, Photowatt will be able to achieve the PV cost reduction goals set by the government agency, Agence Francaise Pour la Maitrise de l'Energie, of $\$ 2.75 / \mathrm{Wp}$. 
Pragma. Pragma of Italy was formed by the state owned oil company ENI. Pragma originally owned a share of Solarex and thus had access to the technology for producing "semix" polycrystalline material. Pragma also owns a controlling interest in Solaris, an Italian licencee of Solarex. Pragma has assembled both single crystal and polycrystalline modules. They are working on A-Si. They reported at the end of 1983 that they had sold their production quota for 1984. Previously they had announced a capacity of $450 \mathrm{~kW}$ per year. They have announced plans to build an automated assembly plant for cells and modules.

Siemens A.G. Interatom is a subsidiary of Siemens that is responsible for a11 PV research, product development and marketing. Siemens' product development strategy has four major elements:

o quality single crystal modules,

- R\&D on low cost silicon purification, using arc furnace technology,

- high speed ribbon production using web-supported horizontal growth,

o amorphous silicon R\&D.

Their single crystal product is marketed worldwide and is used for communications, battery charging, remote residential power, etc. Siemens currently employs about 40 professionals in their PV business.

\subsection{JAPANESE PV INDUSTRY}

The Japanese PV industry has experienced rapid growth over the past four years, with shipments increasing from $0.5 \mathrm{MW}$ in 1980 to $7.7 \mathrm{MW}$ in 1984 . However, unlike U.S. shipments, about $86 \%$ of the Japanese sales are to the nonsubsidized, consumer goods market (see Figure 2.7). The Japanese have viewed this market as a testing ground for developing their thin film technology, as well as a means of expanding their PV production base. By concentrating on the consumer goods market, the Japanese share of the world PV market has increased from $15 \%$ in 1980 to $33 \%$ in 1984 (see Figure 2.5).

Although the Japanese have increased their share of the world PV market, they are still behind the rest of the world in terms of developing large-scale PV power modules. Japanese power modules are currently being test marketed in the U.S.; however, these modules are made from crystalline materials and not 
thin films. In order to help narrow this technology gap, the Japanese government is still providing support to the PV industry through the Sunshine project. In 1983 the Japanese government provided over $\$ 28$ million, and this funding increased to about $\$ 30$ million in 1984 .

Table 2.5 lists the Japanese module manufacturers in 1984. The following section provides background information on the major Japanese module manufacturers.

TABLE 2.5. Major Japanese Module Manufacturers in 1984

$\begin{array}{ll}\text { Fuji Electric Co. } & \text { Maisushia Electric } \\ \text { Hitachi Electric Co. } & \text { Mitaka Electronics } \\ \text { Hoxan Co. } & \text { Nippon Electric } \\ \text { Japan Solar Energy Co. } & \text { Sanyo Electric } \\ \text { Kodenshi } & \text { Sharp } \\ \text { Komatsu Electronics } & \text { Taiyo Yuden } \\ \text { Kyoto Ceramic } & \text { Toshiba }\end{array}$

Fuji Electric was one of the first Japanese PV companies to fabricate large unit A-Si cells on a metallic substrate. Fuji has also constructed a PV residence that uses $3 \mathrm{~kW}$ of modules and a Fuji Power conditioning system. During 1984 Fuji signed an agreement to share A-Si developments with Photowatt of France. Fuji is one of the world's leading producers of A-Si modules for use in calculators and watches.

Hoxan started in 1929 in Sapporo Hokkaida Province as an oxygen production plant. Since then, Hoxan has grown to be a manufacturer of a wide range of industrial and specialty gases, liquid petroleum gas, medical gases and handling equipment.

In 1963, in a joint venture with American Standard, they began production of Bath-A1l bathroom units.

In 1982, Hoxan entered the PV industry with modest production. They recently have dedicated a $9 \mathrm{MW}$, fully-automated PV production facility. This facility is the largest PV manufacturing facility in the world and it converts single crystal silicon slices into 36 -cell, 40 watt modules. A unique feature of this plant is that no people ever contact the modules or cells. 
Kyocera entered the photovoltaics industry in 1979 and has produced modules in the four major PV technologies: polycrystalline silicon single cryustal silicon, amorphous silicon and ribbon. Their ribbon PV technology was developed through a joint venture with Mobil Solar (then Mobil Tyco) in 1979. Kyocera entered the US market vigorously in 1984 selling both modules (multicrystalline) and systems.

Sanyo is reported to be the leading producer of PV in Japan. Sanyo has established an energy division involved in both PV and solar thermal technologies. They recently constructed a $\$ 50$ million PV production plant that is capable of producing 1 million calculator-type modules per month.

Sharp has been in the PV business longer than any other Japanese firm. Currently, Sharp is the principal manufacturer of PV cells for Japanese spacecraft. The company is also involved in manufacturing cells and modules for use in remote stand-alone applications and pocket calculators.

They joined ECD of the USA in a venture with Sharp-ECD developing a roll-toroll A-Si production machine that fabricates A-Si cells on a $180 \mathrm{~cm}$ stainless steel sheet.

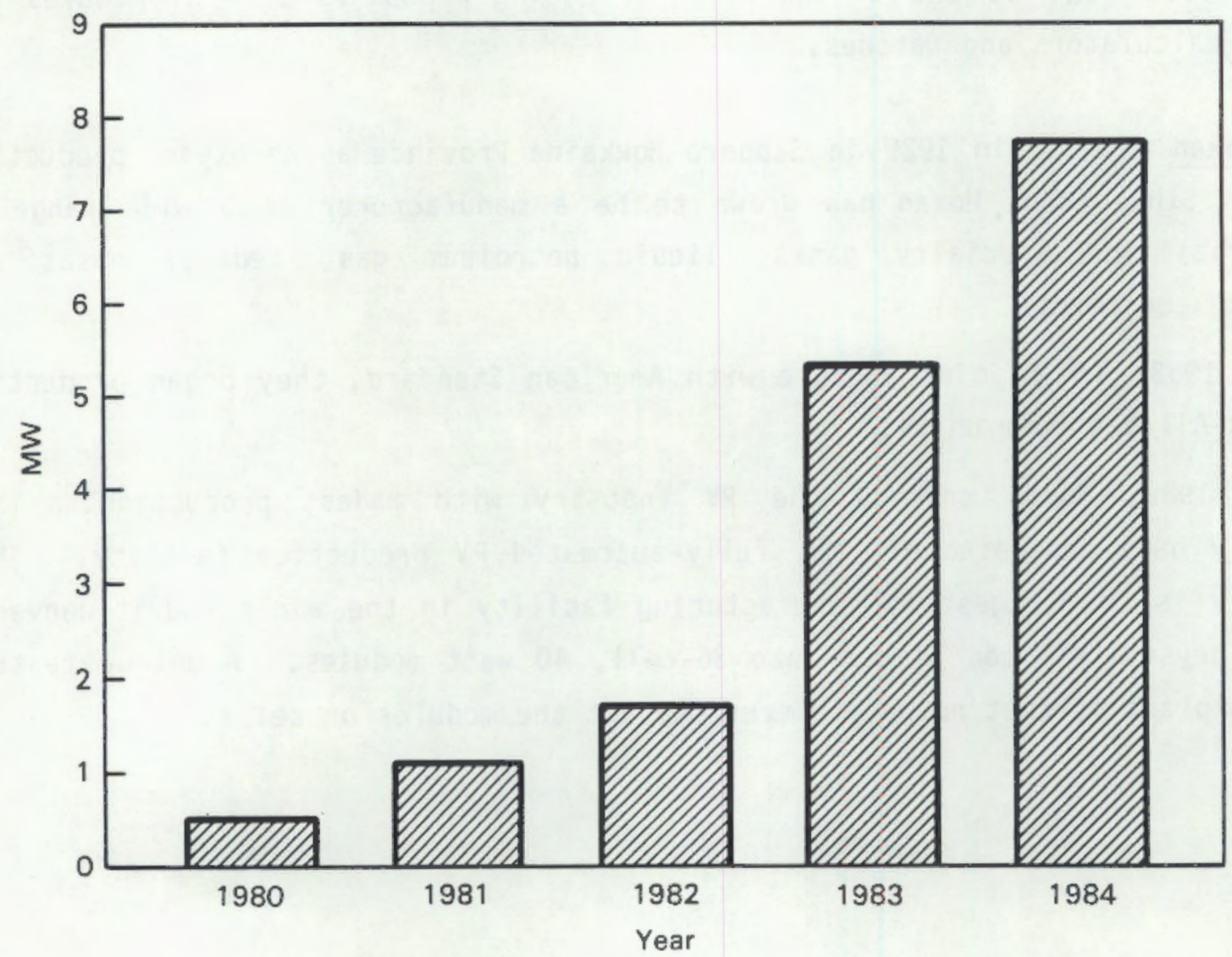

Figure 2.7 Japanese PV Shipments 


\section{4 "OTHER" PV REGION}

The "other" PV region includes primarily those PV companies in Asia and South America. The growth in PV activity in this region has been modestlyincreasing from $400 \mathrm{~kW}$ in 1983 to about $600 \mathrm{~kW}$ in 1984. Two companies are responsible for the growth of this region: CEL and Heliodinamica.

CEL (New Delhi, India). CEL is a government owned PV manufacturer who produces crystalline PV cells, modules, and systems. The technology used was US developed, but the production equipment was made in India. CEL has developed and manufactured PV systems for offshore well-head platforms, telecommunications, weather monitoring and various other industrial applicaitons.

Heliodinamica. This company is a privately-owned PV manufacturer located in Cotia (22 miles outside Sao Paulo) Brazil that entered the PV industry in 1980. Heliodinamica is the first Third World company to manufacture cells, modules and complete PV systems.

They installed Brazil's first PV powered water pumping system in 1981 at Rio Grande do Norte. Since then the company has developed a new motor for its submersible tube well pump as well as an extremely simple priming device for its surface-mounted pumps. Telebras, the government telecommunictions company, is replacing many of its diesel generators at remote sites with PV powered systems, supplied by Heliodinamica. 



\subsection{GOVERNMENT SUPPORT OF PHOTOVOLTAICS}

The world PV industry continued to grow modestly during 1984, and government support of the industry continued to play a major role in this expansion. The financial support given by various governments included direct government purchase, cost-sharing with industry, and indirect goverment support such as tax credits. This chapter summarizes the various forms of support given to the PV industry during 1984.

\subsection{DIRECT FEDERAL PURCHASES}

In the U.S., the Federal Photovoltaic Utilization Program (FPUP) was initiated and funded long before PV shipments actually occurred. This is a natural result of the process of identifying the specific installations to be funded, designing the installations, and procuring the needed equipment. In Figure 3.1, the shipments to FPUP projects are shown for 1980 through 1983. Since only a few PV systems were shipped in 1980, the shipments for 1980 and 1981 are combined. It is interesting to note that shipments actually peaked in 1982.

Other federal purchases included those resulting from the Program Research Development Announcement (PRDA) and other large projects. The funding for large projects may have been fairiy uniform year by year, but some projects lagged behind others, and the result is that actual shipments were much higher some years than others (Figure 3.2 ).

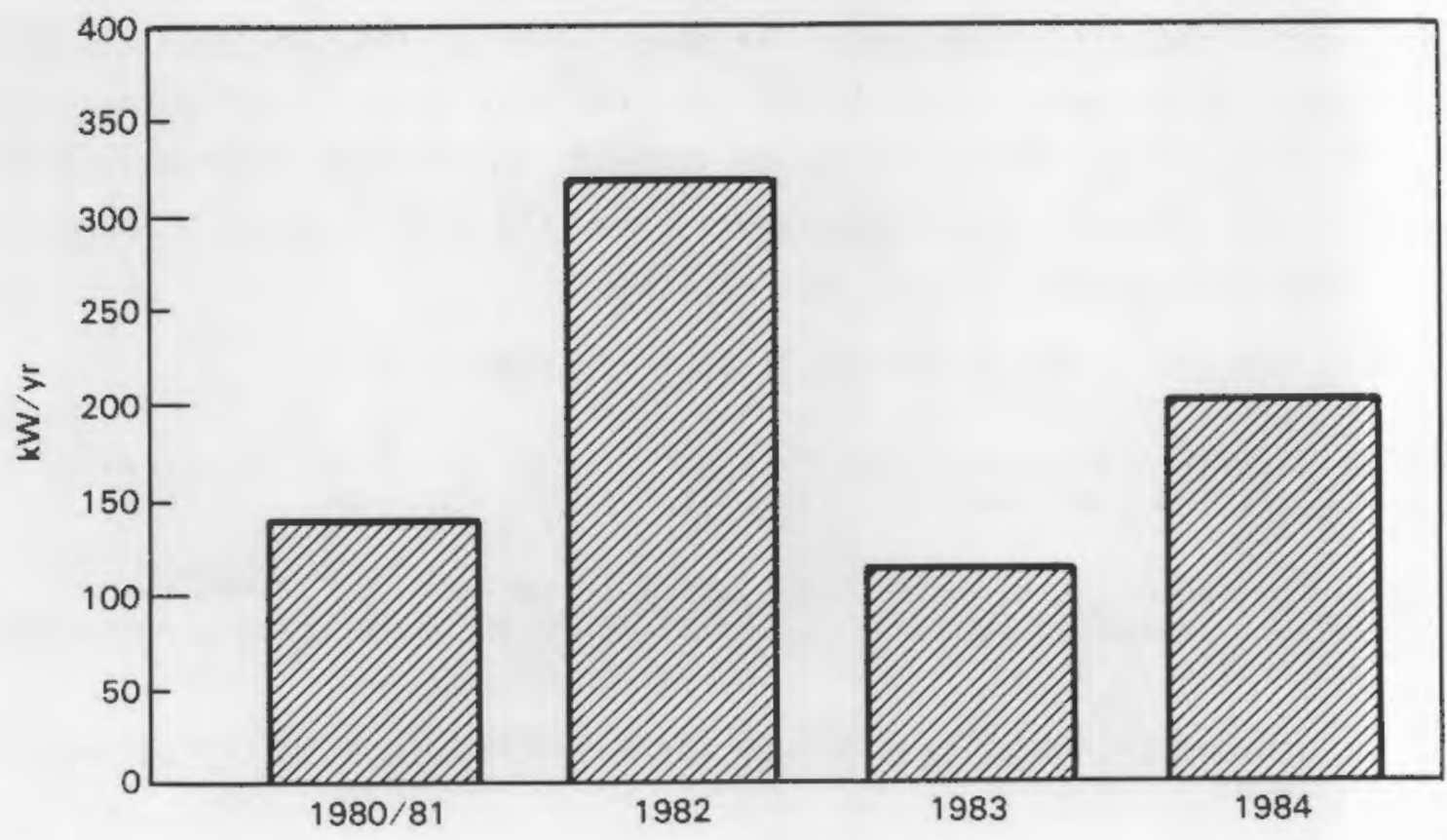

Figure 3.1 Annual FPUP PV Purchases

3.1 


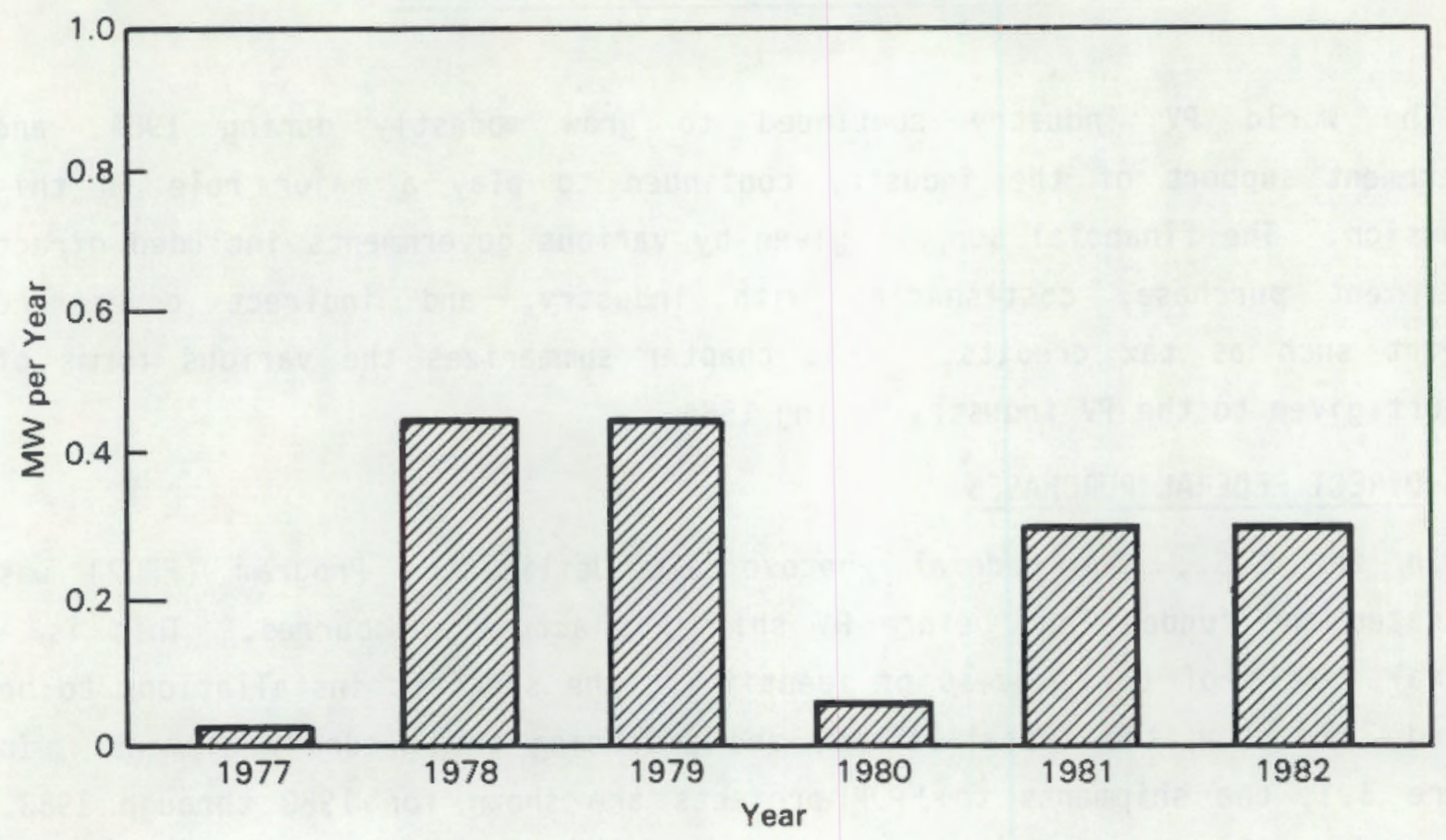

Figure 3.2 Federal, Non FPUP PV Purchases

\subsubsection{U.S. Government Spending}

The U.S. Government, through the Department of Energy's Photovoltaics Division, has been sponsoring PV R\&D for more than 10 years. This funding grew from $\$ 10$ million in 1973 to $\$ 130$ million in 1981. In 1984, the DOE provided more than $\$ 50$ million for PV R\&D.

This federal support, along with the cooperation of industry, has helped to reduce $P V$ electricity costs from $\$ 15 / \mathrm{kWh}$ to less than $\$ 1 \mathrm{kWh}$; to increase cell efficiences from $11 \%$ to $18 \%$; to increase domestic PV production from less than $1 \mathrm{MW} /$ year to $11.6 \mathrm{MW} /$ year; and to improve module life from 2 years to more than 10 years (more than 20 year life is now expected).

In 1982, the goals and objectives of DOE's PV program were:

- to develop new materials by FY 1985 in order to establish technical feasibility for industry-produced $\$ 0.77 /$ Wp collectors,

- to develop critical balance of system components by FY 1985 that support installed system costs of $\$ 1.75-\$ 2.45 /$ Wp in utility-connected applications, and

- to achieve technical feasibility for less than $\$ 0.45 /$ Wp collectors by FY 1990. 
Program goals and objectives were revised for the FY 1984-1988 program. These goals and objectives are:

- to achieve flat plate system module costs and efficiences in the range of $13-17 \%$ and $\$ 40-\$ 75 / \mathrm{sq}$. M., and

- to achieve concentrator system module costs and efficiency in the range of $23-29 \%$ and $\$ 90-\$ 160 / \mathrm{sq}$. M.

The program's emphasis has changed from aggressive market development activities prior to 1982 to concentrating on advanced R\&D.

\subsubsection{European Funding}

For several years individual European governments have been funding PV R\&D activities. However, in 1975 the eight member countries of the European Economic Community (EEC) joined together to fund PV R\&D through the Commission of European Communities (CEC). In 1982 approximately $\$ 49$ million of CEC funding and indirect industry cost sharing were available for PV research. This funding is used by universities for advanced cell research activities, and by industry for PV technology development.

The CEC also sponsors 15 PV pilots, 13 of which are operating (see Table 3.1). The objectives of these experiments are:

- to develop and demonstrate PV system design for specific applications;

- to promote user acceptance by aesthetic designs of PV arrays which blend in with the environment;

o to develop new technologies; and

- to provide incentives to European industry, utilities, and national regional authorities in the PV program.

All pilot programs are co-sponsored by the respective national governments, with the CEC contributing about $30 \%$ of the cost of these projects. About $50 \%$ of the funding is from the PV industry and national governments. The CEC's future budget for PV R\&D activities is expected to be determined by the end of 1984 or early 1985. It is also expected that proposals will be invited in 1985 for a new series of pilot projects including hybrid, wind/PV or diesel/PV, systems. 
TABLE 3.1 Operating European Pilot Plants

\begin{tabular}{|c|c|c|c|c|}
\hline Location & $\begin{array}{l}\text { Power } \\
\mathrm{KW}\end{array}$ & Application & $\begin{array}{c}\text { Leading } \\
\text { Contractor } \\
\end{array}$ & Co-Sponsor \\
\hline $\begin{array}{l}\text { Pell worm Island, } \\
\text { West Germany }\end{array}$ & 300 & $\begin{array}{l}\text { Power for recre- } \\
\text { ation center }\end{array}$ & AEG Telefunken & $\begin{array}{l}\text { West German govern- } \\
\text { ment }\end{array}$ \\
\hline $\begin{array}{l}\text { Kthos [s] and, } \\
\text { Greece }\end{array}$ & 100 & Island grid & Sienens $A G$ & $\begin{array}{l}\text { W. German govt. and } \\
\text { Greek uttlity }\end{array}$ \\
\hline Chevetogne, Belgium & 63 & $\begin{array}{l}\text { Punps for swimm- } \\
\text { ing pool and } \\
\text { lighting }\end{array}$ & IDE-ACEC & Belgiun government \\
\hline $\begin{array}{l}\text { Aghia Rounell. } \\
\text { Greece }\end{array}$ & 50 & Village grid & Renault & $\begin{array}{l}\text { French govt. and } \\
\text { Chamber/Commerc }\end{array}$ \\
\hline Iont Bouquet, France & 50 & TV transmitters & Photowatt, Inc. & $\begin{array}{l}\text { French govt. and } \\
\text { Chamber/Comnerce }\end{array}$ \\
\hline Nice Airport, France & e 50 & Tower control & Photowatt, Inc. & $\begin{array}{l}\text { French govt. and } \\
\text { Chamber/Commerce }\end{array}$ \\
\hline Fota Island, Ireland & 50 & Dairy farm & $\begin{array}{l}\text { U. of Cork, } \\
\text { AEG }\end{array}$ & $\begin{array}{l}\text { Irish \& German govt } \\
\text { \& Irish utility }\end{array}$ \\
\hline $\begin{array}{l}\text { Terschelling Island, } \\
\text { The tetherlands }\end{array}$ & 50 & Martne school & Holec & $\begin{array}{l}\text { Dutch \& Ge:man } \\
\text { governments }\end{array}$ \\
\hline Kaw, French Guyana & 35 & Village grid & Renault & French goverment \\
\hline Hoboken, Belgium & 30 & Electrolysis & ENI & Belgian government \\
\hline Rondulinu, Corsica & 30 & Village power & Leroy-Somer & $\begin{array}{l}\text { French govt. and } \\
\text { French utility }\end{array}$ \\
\hline $\begin{array}{l}\text { Treniti Is] and, } \\
\text { Italy }\end{array}$ & 65 & $\begin{array}{l}\text { Seawater desalf. } \\
\text { nation }\end{array}$ & Italenergie & Italian government \\
\hline Giglio Isl and, Italy & 45 & $\begin{array}{l}\text { Water disinfec- } \\
\text { tion and cold } \\
\text { storage }\end{array}$ & Pragma & $\begin{array}{l}\text { Italtan govt, and } \\
\text { Toscana Gigi io } \\
\text { community }\end{array}$ \\
\hline $\begin{array}{l}\text { Vulcano [s] and, } \\
\text { Italy }\end{array}$ & 80 & Village power & ENEL. & Italian utility \\
\hline Marchwood, UK & 30 & Grid interaction & BP Solar & British government \\
\hline TOTAL. & 1028 & & & \\
\hline
\end{tabular}

Source: Starr, M.R. 1983. Photovoltaic Power for Europe. D. Reidel Publishing. Appendix B. pp. 194-195.

\subsubsection{Japanese Funding}

The majority of Japanese support of PV is provided by the Sunshine Project which is administered by the Agency of Industrial Science and Technology under the Ministry of International Trade and Industry. The Sunshine Project is formulated after the U.S./DOE PV program in terms of discipline areas. The three major areas of PV research are 
- PV technology development

- PV system technology, including PV applications, and

- PV materials research.

The objective of the Japanese PV research is to make the best use of U.S.developed silicon technologies for the development of viable silicon crystaline mass production capabilities, and to make Japan a leader in A-Si cell technology. Japan's emphasis on A-Si is due to their silicon availability problems and the high costs of silicon refinement.

PV funding by the Sunshine Project has increased rapidiy since 1980 to over $\$ 30$ million for 1984 (see Table 3.2). These funds are used by about 14 companies for performing PV production-related work, and by 6 universities for PV device physics research. Funds cover the purchase of capital equipment, expendables, and a portion of direct labor costs. The contractors provide internal funds for the majority of labor costs.

TABLE 3.2 Sunshine Project vs. U.S. PV Funding

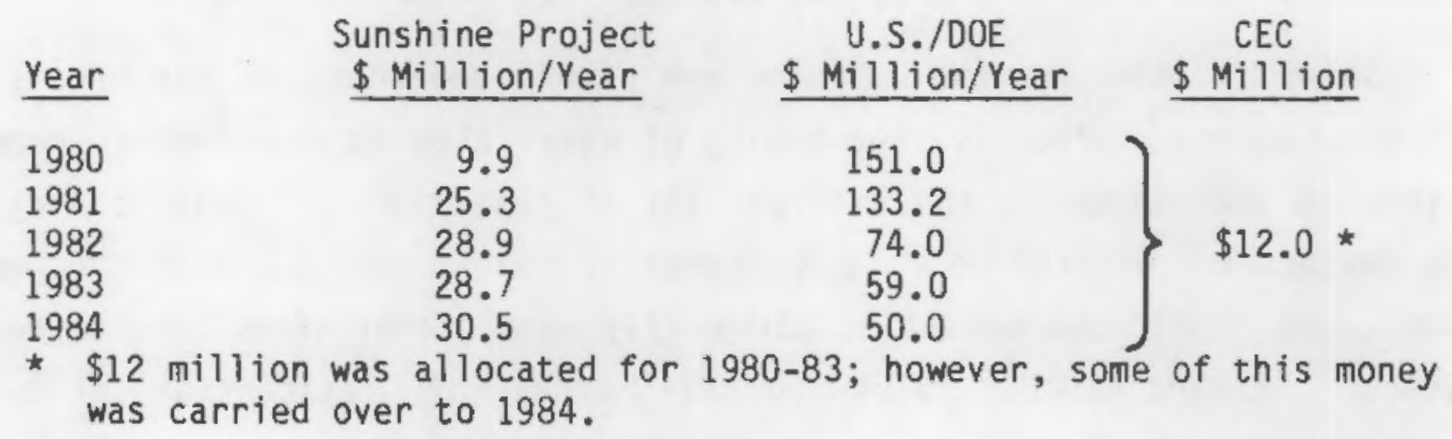




\subsection{INDIRECT FEDERAL SUPPORT}

In addition to the direct U.S. Government purchases, there is a large part of the total sales that contains federal or state tax subsidies. Large private sales, such as the $200 \mathrm{~kW}$ solar breeder by Solarex, the $1.0 \mathrm{MW}$ Lugo station installation by ARCO, and the majority of the PV concentrators being installed by UEC, are subsidized by federal and state tax incentives. Dealers and distributors indicate the tax credits are still an important consideration when selling to the residential market.

To encourage the use of renewable energy sources in the U.S., the Federal Government and many states are offering energy tax credits of one form or another. These tax credits have a great effect on sales in some areas and almost no effect in others. Tax credits are available for PV-powered communications equipment but are not a consideration of primary importance in their purchase because PV currently offers the most economically viable option for providing power to repeaters in remote locations. Dealers and distributors contacted indicated that only a very small percentage of sales made in the communications area is due to the availability of tax credits.

Sales in other market segments are highly dependent on tax breaks given to PV purchasers. Currently, the timing of many sales to residential remote power users is determined by the availability of tax credits. This is very apparent to dealers and distributors, as December is the largest sales month for many of them, and fourth-quarter sales can easily equal total sales for the rest of the year. Expanding US sales in the areas of residential grid-connected applications (selling the excess power to utilities at the utility's avoided cost of power) and agricultural water pumping and irrigation are going to be largely contingent on tax credits until the cost per watt of a PV system falls.

Federal tax incentives for installing PV systems are available in many forms. First, eligible non-residential systems receive a $10 \%$ investment tax credit in the first year of operation. Residential systems do not qualify for this credit. The term "non-residential" is used to represent commercial, industrial, and agricultural uses as stated in the tax laws. Also available to non-residential users in the first year of operation is the federal energy tax 
credit of $15 \%$ which expires at the end of 1985 . Non-residential PV systems are currently able to be depreciated over five years under the accelerated cost recovery system (ACRS). However, the depreciable basis of the system must now be reduced by $50 \%$ of the regular and investment tax credits according to the Tax Equity and Fiscal Responsibility Act of 1982.

Residential PV systems are eligible for a federal residential energy credit of $40 \%$ of expenditures up to $\$ 10,000$. This is a maximum credit of $\$ 4,000$ which is applied on a cumulative basis. The credit is available to the person making the qualified expenditure, and thus ownership of the residence is not a requirement. This credit is also due to expire at the end of 1985 .

To show the effects of the various tax credits, two examples--residential and non-residential--will be presented. The California tax laws will be used because of the large PV market in California and the liberal tax credits.

According to the California Energy Comission, residential and nonresidential tax incentives are available through the end of 1986. For residential users, a $50 \%$ tax credit is available on equipment purchases, with a tax credit limit of $\$ 3000$. This credit is taken net of the federal credit to make the maximum combined tax credit $50 \%$. For apartment buildings, this credit is applied on a per-unit basis. For non-residential users only, there is a $25 \%$ solar tax credit. This credit is added to any federal tax credits that the equipment is eligible for and has no dollar limit. Equipment purchased by nonresidential users can also be depreciated over three years, using the doubledeclining-balance method; however, the depreciable basis must be reduced by the amount of the state tax credit taken.

Figures 3.3 and 3.4 show the impact of tax credits on the effective (after tax) cost/watt and on total dollar tax savings for the residential PV purchaser. In figure 3.3, the effective cost per peak watt for PV systems is shown to fall slowly with increasing numbers of panels purchased. At 30 panels, the cost per peak watt begins to rise as the available tax credits have been exhausted as seen in Figure 3.4. The reason for the downward trend in price per watt before 30 panels is due to balance-of-system costs falling as a percentage of total cost. The discontinuities in Figure 3.3 at 5 and 50 panels are due to quantity discounts. 


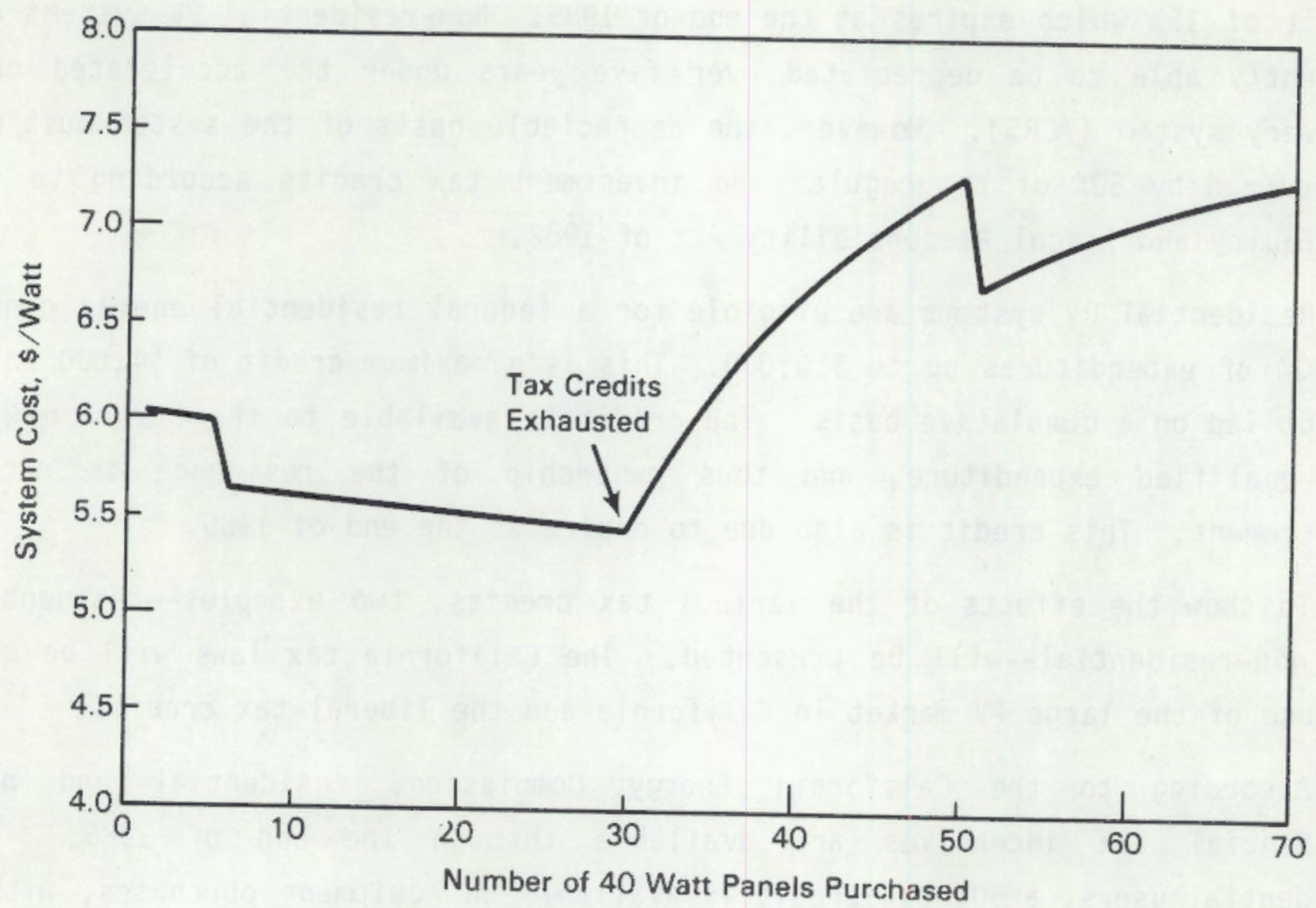

Figure 3.3 Effective (after tax) Cost Per Watt for Residential PV Systems

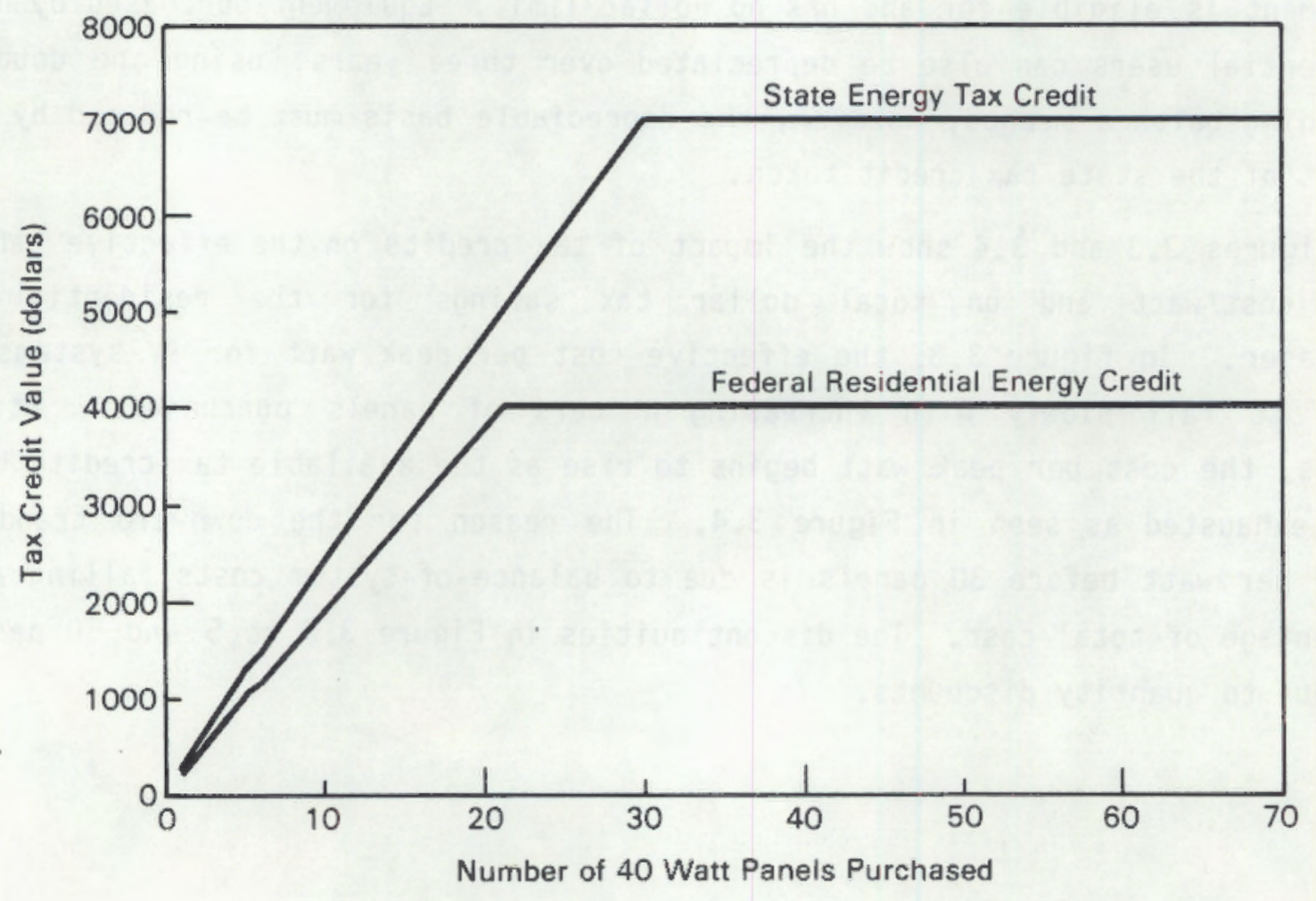

Figure 3.4 Dollar Value of Tax Credits (Residential) 
In Figure 3.5, the effect of a $\$ 1 /$ Wp reduction in the price of modules is shown for residential PV system purchases. Due to state and federal tax credits, the effective system cost is lowered by only $\$ .50$ per watt for purchases of 30 modules or less. As the quantity of modules purchased increases, the savings approach $\$ 1$ per watt. But because residential purchasers normally buy less than 30 modules, small decreases in the price of modules cannot be expected to result in large increases in the quantity of modules sold to residential users.

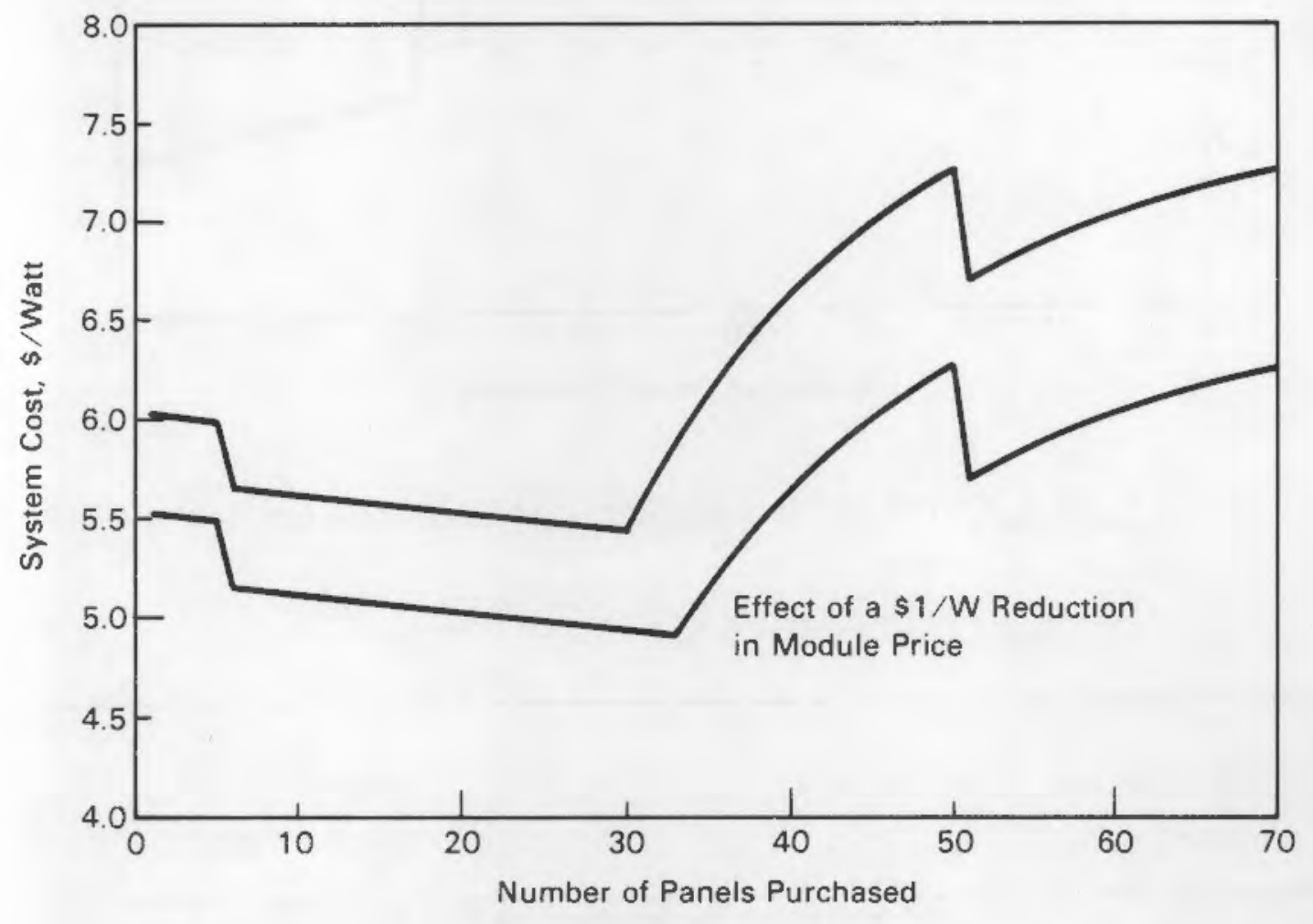

Figure 3.5 Effect of Module Cost Reductions (Residential)

Figures 3.6 and 3.7 show the impact of tax incentives on the effective cost/watt and the percentage of the cost actually paid by the government for non-residential PV system purchases. In Figure 3.6, the effective cost per peak watt slowly falls with increasing numbers of panels purchased. Again, the reason for the downward trend is the decreasing percentage of total cost that balance-of-system costs represent; as before, the discontinuities at 5 and 50 panels are due to quantity discounts. Figure 3.7 shows that since there is no dollar limit on the amount of tax incentives for non-residential purchasers, the government pays a full $72 \%$ of the cost regardless of the number of panels. 


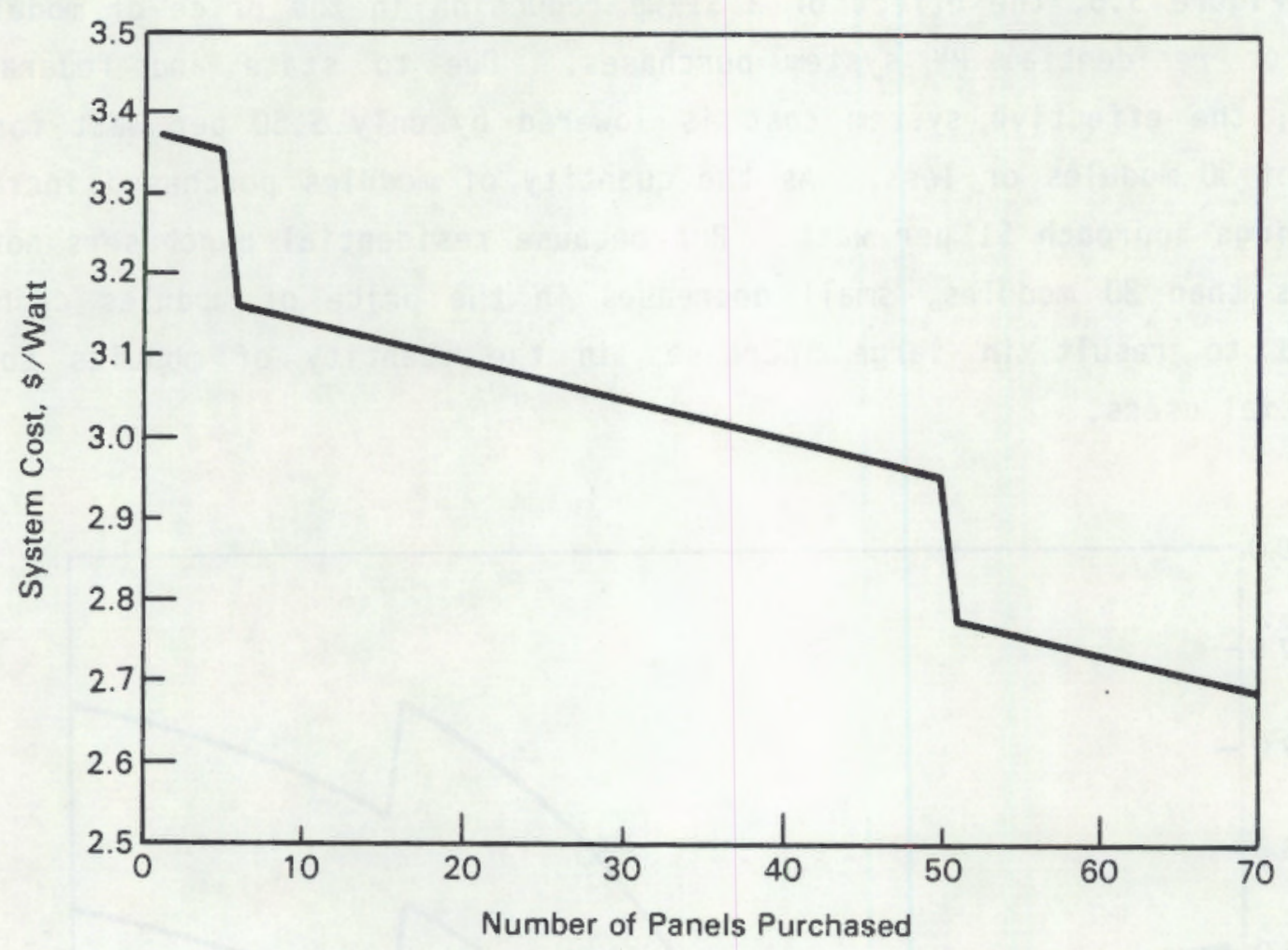

Figure 3.6 Effectife Cost Per Watt (Non-Residential)

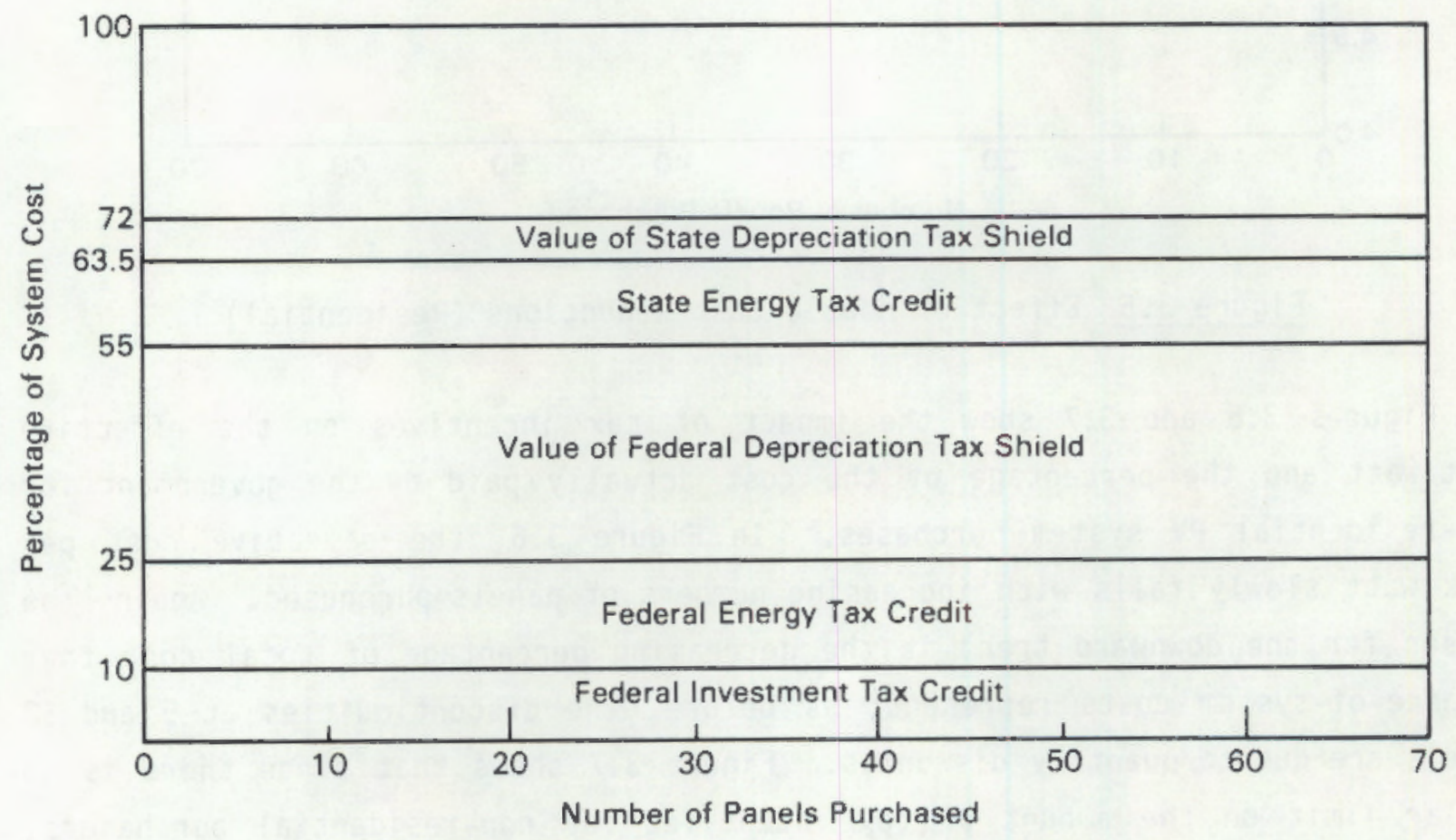

Figure 3.7 Tax Incentives for Non-Residential Systems 
Since the payment of state taxes is deductible from income for federal income tax purposes, the value of the state tax credit and state depreciation tax shield is reduced by the marginal federal income tax rate. For example, a $25 \%$ state tax credit will only reduce the total tax bill by $13.5 \%$ of the amount eligible for the credit if the applicable marginal federal income tax rate is $46 \%$.

For the examples shown, certain assumptions were required, and these are listed below:

- The party making the purchase would be eligible for the credits described above.

- The marginal federal income tax rate of non-residential purchasers is $46 \%$.

- The marginal California income tax rate of non-residential purchasers is $9.6 \%$.

- The appropriate discount rate for depreciation is $10 \%$.

- All parties have income great enough to fully use the tax credits and depreciation in the first year they are available.

- Residential purchasers were assumed to itemize deductions for federal income tax purposes. If a residential purchaser itemized deduction, the dollar value of the state energy tax credit shown in figure 3.4 could be reduced by up to $50 \%$, or a maximum of $\$ 1500$.

- Forty-three watt panels can be purchased for the following prices per peak watt:

\section{Number of Panels}

5 or less

6 to 50

Over 50

\section{Price per Peak Watt}

$\$ 9.00$

8.50

8.00

- Balance-of-system costs were estimated from available information. They include the cost of mounting structures, wire, batteries, control equipment, and inverters. Specifically, they decreased linearly from 34 to $20 \%$ for 0 to 70 panels, respectively.

- Installation costs were not considered. 



\subsection{MARXET SECTOR COMPARISONS}

In this section, the annual shipments of PV modules are subdivided according to customer, end-use, and technology sectors. Estimating the shipments to both the customer and end-use sector is extremely difficult since modules are often sold by the manufacturer to distributors who, in turn, sell the modules to the ultimate customer. In such cases, the original manufacturer has no information on the customer or end-use of the equipment.

The market sector designations used in this section were developed through a cooperative effort of PNL, the Jet Propulsion Laboratory (JPL), and the Energy Information Administration (EIA). Definitions of these market sectors are given below to assist the reader in interpreting and using the results.

Customer market sectors are used to identify which portion of the public has purchased PV. Customer market sectors include:

- Residential: individuals who purchase PV for use on their home and RV.

o Commercial: individuals or companies who purchase PV for use in their business or to produce power for a commercial building. It also includes systems houses who will design and assemble PV systems using off-the-shelf PV products and components.

- Agricultural: individuals or organizations who purchase PV for use on a farm or ranch.

- Industrial: individuals or organizations who purchase PV through third party arrangements, or for utility applications.

- Governmental Organizations: organizations, agencies, or villages who purchase PV.

- Consumers: individuals who purchase small appliances and products that use PV such as radios, calculators and watches.

End-use market sectors are used to help determine the amount of PV being installed in large and small, grid vs. non-grid connected applications. These sectors include:

- Stand-alone applications: includes private residences, commercial establishments and agricultural and village power systems that are not connected to the electrical power grid. 
- Grid-connected residences: includes single and multiple-family residences that generate a portion of their power requirements and use the existing power grid for additional power. Any surplus power generated by grid-connected PV systems is sold back to the utility.

- Grid-connected, intermediate sized, commercial applications: includes power generation for use in local retailing or manufacturing facilities excess power is sold back to the utility.

- Central station: includes facilities that produce power for sale to local utilities.

o Specialty: includes consumer goods and appliances.

\subsection{CUSTOMER MARKET SECTORS}

The time series break-down of PV shipments by customer market sector is presented in Table 4.1 All customers sectors have grown in absolute tems since 1981 with the most dramatic increase in PV usage by industrial customers. Growth in the industrial sector has been driven by both the attractiveness of PV in utility applications and third party arrangements. The relative importance of this market sector has increased from $4 \%$ of world sales in 1981 to $40 \%$ in 1983 (Figure 4.1). Purchases of PV by the industrial sector declined by $2.7 \mathrm{MW}$ during 1984 due to questions as to the legality of some third party arrangements. Consequently, the industrial sector's market share declined to $21 \%$ in 1984 and is expected to decline further in 1985.

Use of PV by the commercial sector grew by $71 \%$ during 1984 and represents the largest growth of any customer sector. This growth is primarily due to the increased use of distributors and systems houses by PV manufacturers. Aithough this shift makes it much more difficult to identify the ultimate customer, it does indicate that the PV industry infrastructure is growing, and that $P V$ manufacturers are relying more heavily on these firms to market and to sell their products.

The consumer sector increased by $56 \%$ during 1984 spurred by the expanded use of PV in radios, watches and calculators manufactured by the Japanese. The share of PV shipped to the consumer market sector increased from $19 \%$ of the total market in 1983 to $27 \%$ of the market in 1984. This sector is expected to continue to grow for the next few years (in terms of MW shipped as well as market share) as new, low power uses for PV are developed, and as the Japanese continue to expand their production base. 


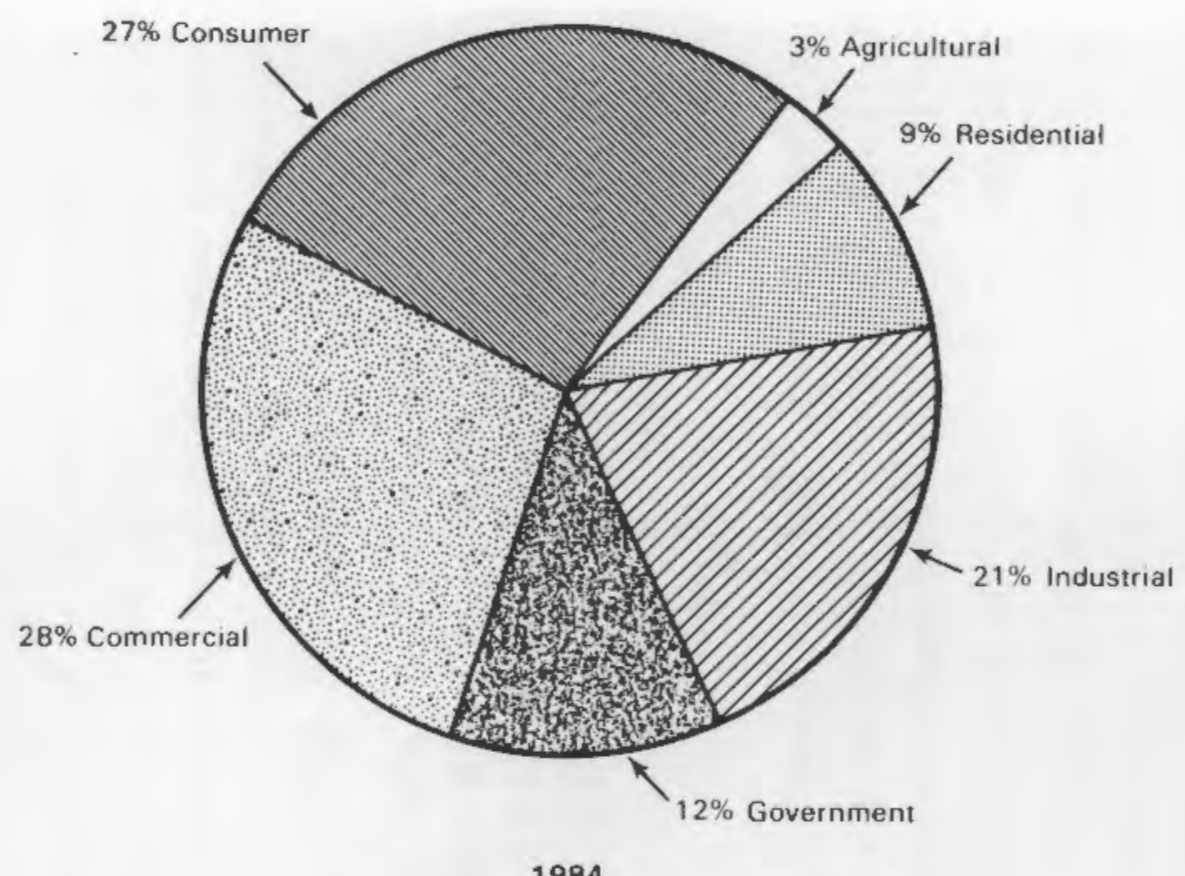

1984

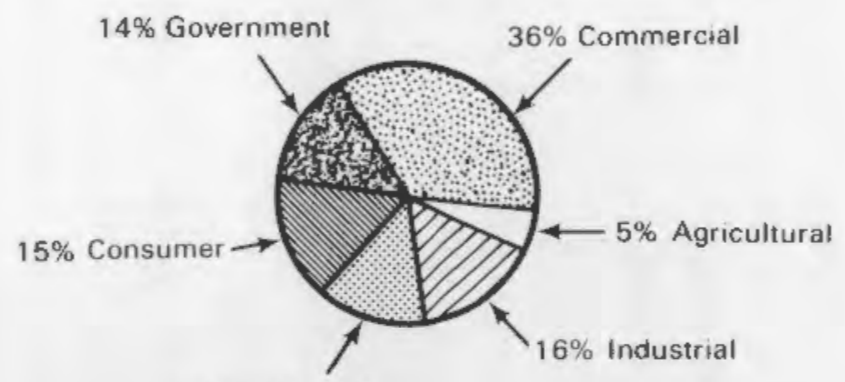

14\% Residential
$19 \%$ Consumer
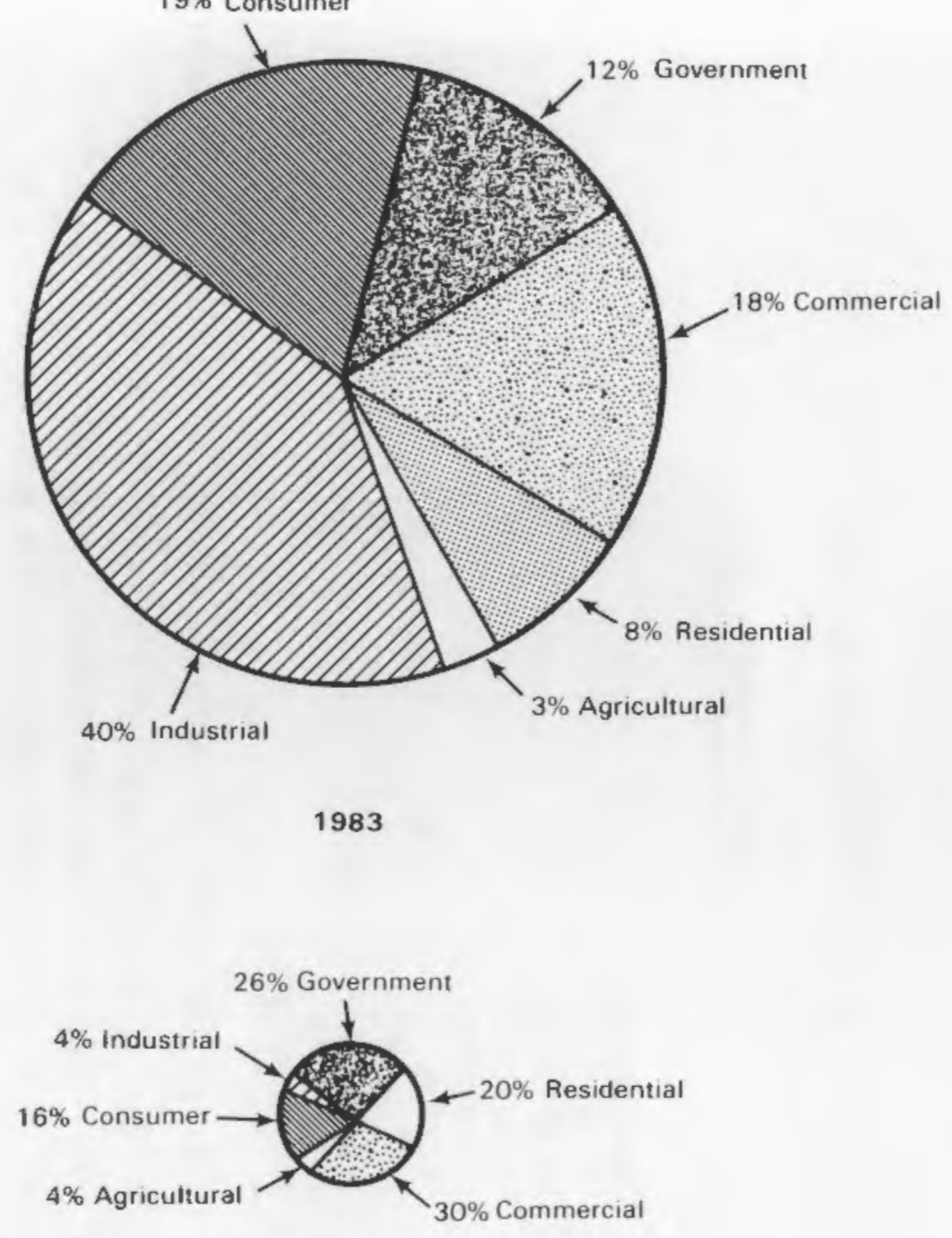

1981 
TABLE 4.1. Shipments to Customer Market Sectors

\begin{tabular}{lrrrrr} 
& \multicolumn{1}{c}{1981} & \multicolumn{1}{c}{1982} & 1983 & 1984 \\
\cline { 2 - 5 } & \multicolumn{4}{c}{ (MN/year) } \\
Residential & 1.0 & 1.0 & 1.8 & 2.1 \\
Commercial & 1.4 & 2.7 & 3.8 & 6.5 \\
Agricultural & .2 & .4 & .7 & .6 \\
Industrial & .2 & 1.2 & 8.7 & 5.0 \\
Government & 1.2 & 1.0 & 2.5 & 2.7 \\
Consumer & .8 & $\underline{1.2}$ & $\underline{4.0}$ & $\underline{6.3}$ \\
TOTAL & 4.8 & 7.5 & 21.5 & 23.2
\end{tabular}

\subsection{END-USE MARKET SECTORS}

The time series breakdown of market sectors by end-use is presented in Table 4.2. Again, all sectors show a significant increase in MW of PV shipped between 1981 and 1984, with the most dramatic increase occuring in the central station sector. The relative importance of this end-use sector, as illustrated by its share of the total market, has increased from $0 \%$ in 1981 to $25 \%$ in 1984 (Figure 4.2). However, the shipments of PV to this sector actually declined during 1984 due to questions as to the legality of third party arrangements.

Stand-alone applications continued to be the largest end-use market in 1984 accounting for $46 \%$ of all PV modules shipped during the year. It is expected that stand-alone applications will predominate for several more years since PV has a distinct cost advantage over conventional energy sources in many of these applications.

Specialty markets increased their share of the end-use market from 1983 to 1984 growing from $19 \%$ to $27 \%$. This growth was primarily due to the increase use of PV in consumer products such as watches and calculators. The specialty end-use sector will continue to grow as the existing markets for PV-powered products expands and as new. low power applications for PV are discovered.

The grid-connected sectors did not grow during 1984. For various reasons, tax credits do not tend to encourage the construction of small PV applications. The transaction costs involved in purchasing a PV system represent more of a hinderance and reduce the attractiveness for small residences. It is not anticipated that this end-use sector will grow in the next few years. 

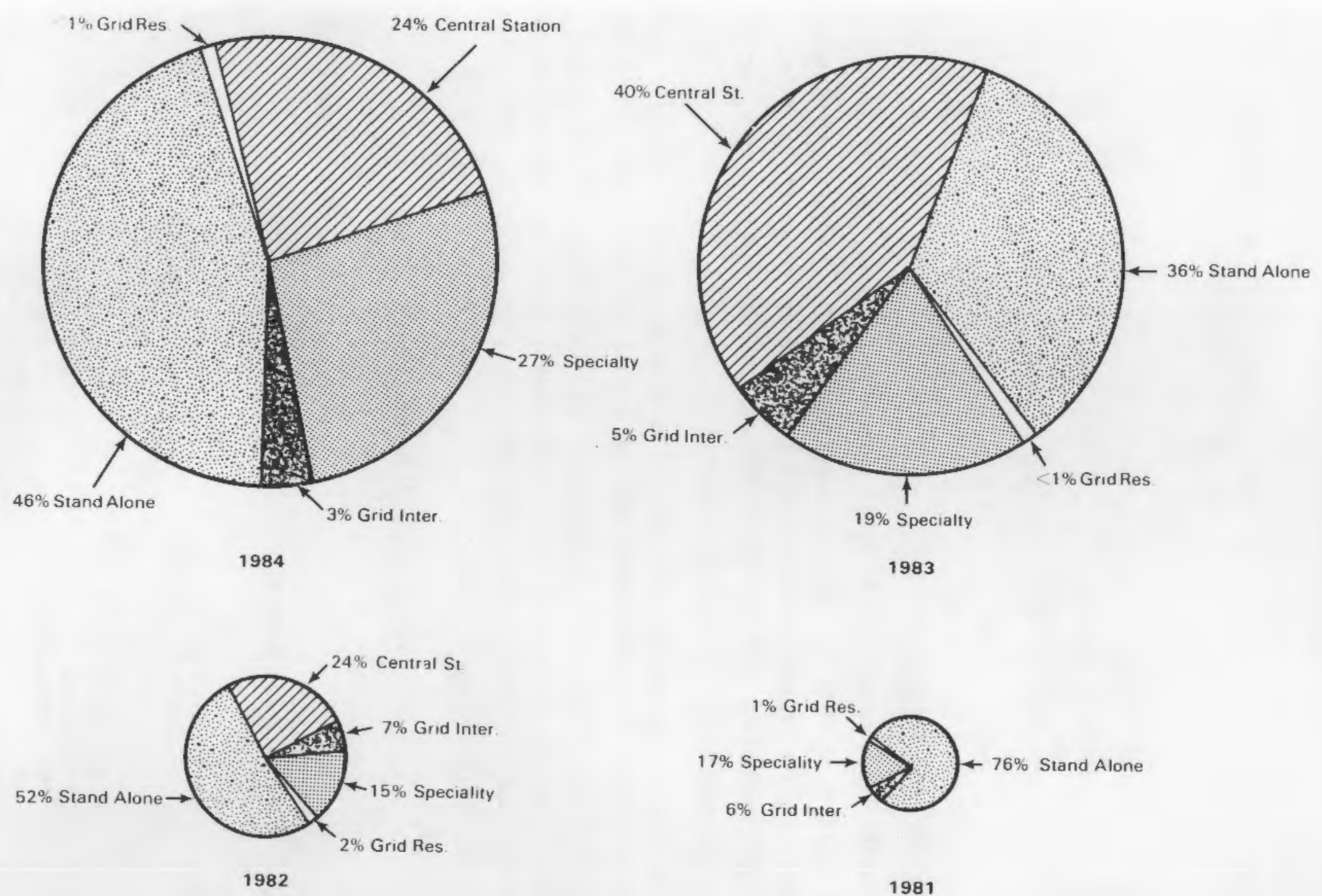

1981 
TABLE 4.2. Shipments to End-Use Market Sectors

$\frac{1981 \quad 1982 \quad 1983 \quad 1984}{(\text { MW/year })}$

$\begin{array}{lrrrr}\text { Specialty } & .8 & 1.2 & 4.1 & 6.2 \\ \text { Stand-Alone } & 3.6 & 3.9 & 7.7 & 10.7 \\ \text { Grid Residential } & .1 & .1 & <.1 & <.1 \\ \text { Grid Intermediate } & .3 & .5 & 1.0 & .6 \\ \text { Central Station } & .0 & \underline{1.8} & \underline{8.7} & \underline{5.7} \\ \text { TOTAL } & 4.8 & 7.5 & 21.5 & 23.2\end{array}$

\subsection{TECHNOLOGY SHARE}

During 1984, commercial PV cells were made by using five different technologies: single crystalline silicon, amorphous silicon, Semix, concentrators, and ribbon. Single crystalline silicon $(\mathrm{Cz})$ continues to be the technology leader, although technology competition increased in 1984 reducing its market share from $49 \%$ in 1983 to $44 \%$ in 1984 (Figure 4.3 ).

The loss of market share by $\mathrm{Cz}$ can be attributed to its failure to achieve the significant cost reductions that it had in the past, and to the technical progress made in the A-Si technology. $\mathrm{Cz}$ could have lost additional market share in 1984 if it were not for its relatively higher efficiency and resulting lower balance of systems costs. Table 4.3 lists the major PV manufacturers who used the $\mathrm{Cz}$ technology in 1984.

\section{TABLE 4.3. PV Manufacturers Using \\ Cz Technology in 1984}

Ansaldo

ARCO Solar

Baharat Heavy Electric

Belgosolar

BP Solar

Central Electronics

Continental Development

Energia Tideland S.A.

Free Energy Systems

Gem Manufacturing

Heliodynamica

Helios Technology

Hoxan

Isophoton

Kodenshi

\author{
Komatsu Electronics Technology \\ Nippon Electric \\ Photowatt S.A. \\ Pragma \\ Sharp Company \\ Siemens A.G. \\ Silicon Sensors \\ Solar Generators \\ Solar Power Corp. \\ Solavolt International \\ Solec International \\ Solenergy \\ Spire Corporation \\ Tideland Signal \\ Tideland Signal Ltd. \\ UEC
}




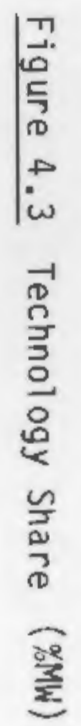
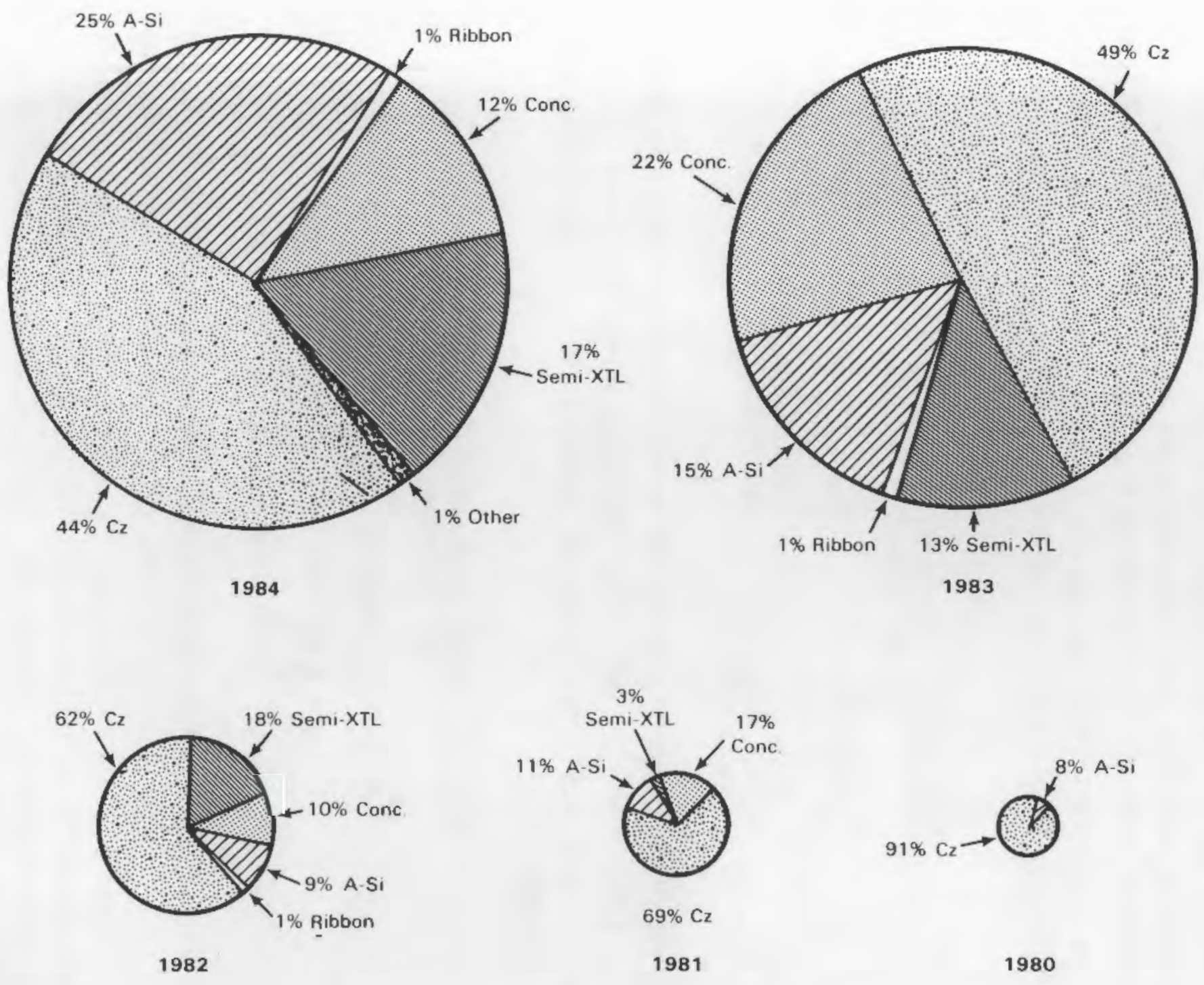
The PV industry is continuing to learn more about the A-Si technology and consequently is solving many of its technical problems. As the technology improves, more low-power uses for A-Si are being discovered. During 1984 the first A-Si power module (5 watts) was introduced by ARCO Solar, and the Japanese continued to find new, low-power uses for the technology. As a result, the market share for A-Si increased from 15\% in 1983 to $25 \%$ in 1984. This trend is expected to continue as the technology improves and additional uses are discovered. Table 4.4 lists the major PV manufacturers who used A-Si in 1984.

TABLE 4.4. PV Companies Developing

A-Si Technology in 1984

$\begin{array}{ll}\text { ARCO Solar } & \text { Sanyo Electric } \\ \text { Chronar } & \text { Sharp } \\ \text { ECD } & \text { Taiyo Yuden } \\ \text { Fuji Electric } & \text { Tenjin Ltd. } \\ \text { Kyoto Ceramic } & \end{array}$

Semix Crystalline technology market share has increased from $3 \%$ in 1981 to about $17 \%$ in 1984, primarily due to an increased number of Semix licensees world wide. Table 4.5 lists major PV manufacturers who used the Semix technology in 1984.

TABLE 4.5. Major PV Manufacturers Using

Semix Technology in 1984

$\begin{array}{ll}\text { Adriatica Componeti } & \text { Holec Solar Energy } \\ \text { AEG Telefunken } & \text { Hoxan Company } \\ \text { Energie Nouvelle } & \text { Komatsu Electronics } \\ \text { France Photon } & \text { Kyoto Ceramic } \\ \text { Hitachi Electric Co. } & \text { Solarex Corporation }\end{array}$

Concentrator market share has also increased dramatically, from 17\% in 1981 to $22 \%$ in 1983. United Energy Corporation's third-party financed sales of their solar thermal/PV system represent the primary factor in this increase. In 1984 concentrator's market share fell to $13 \%$ due to questions as to the legality of some third party arrangements. Table 4.6 lists the major PV manufacturers who used concentractors in 1984. 


\section{TABLE 4.6. Major PV Manufacturers Using Concentrator Technology in 1984

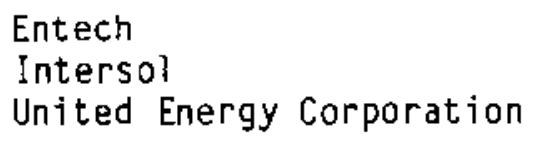

Ribbon technologies have not captured a significant share of the market in 1984, since each company, Mobile, Solavolt and westinghouse, is in the process development stage. 
APPENDIX A

1984 PV CURRENT EVENTS 


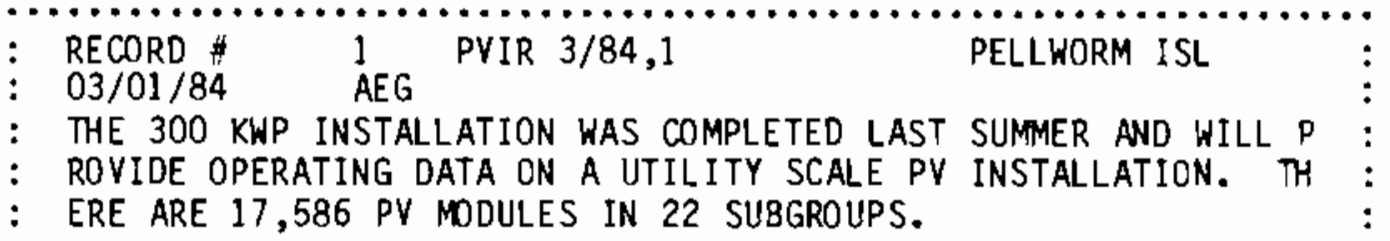

RECDRD
$04 / 01 / 84$
RECEIVED AN ORDER FROM EGYPT TO SUPPLY 400 PV POWERED NAVIGAT
IONAL AIDS FOR USE IN THE SUEZ CANAL.

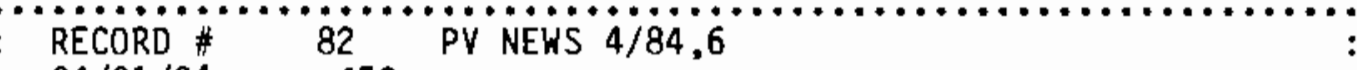

has COMPLETED thEIR MULTI MN PRODUCTION FACILITY at WEDEL. TH:

EY PRODUCED $900 \mathrm{KW}$ IN 1983. NOW HAVE US SALES OFFICE (201) 72 :

2-9800, MIKE MONROE.

RECORD \# 322 PV INTERN $i \stackrel{10}{10} / 84,1$

10-01-84 AEG TELEFUNKEN

WEST GERMANY

PELLWORM ISLAND PY STATION IS NOW OPERATIONAL. THE $300 \mathrm{KW}$ SY

STEM IS SUPPLYIMG POWER TO A THERAPEUTIC CENTER ON THE ISLAND

: SPONSORED BY THE EEC.

$\because$ RECORD \#

06/18/84 AIRTRICITY

PV/WIND FARM DEVELOPER CLOSED A DEAL WITH HOLEC TO ACOUIRE TH

: E RIGHTS TO TWO TURBINES. THEY ARE DEVELOPING A FARM USING 50 :

: KW OF HOLECSOL'S $40 \mathrm{~W}$ POLY MDDULES. 


\section{PV EVENTS}

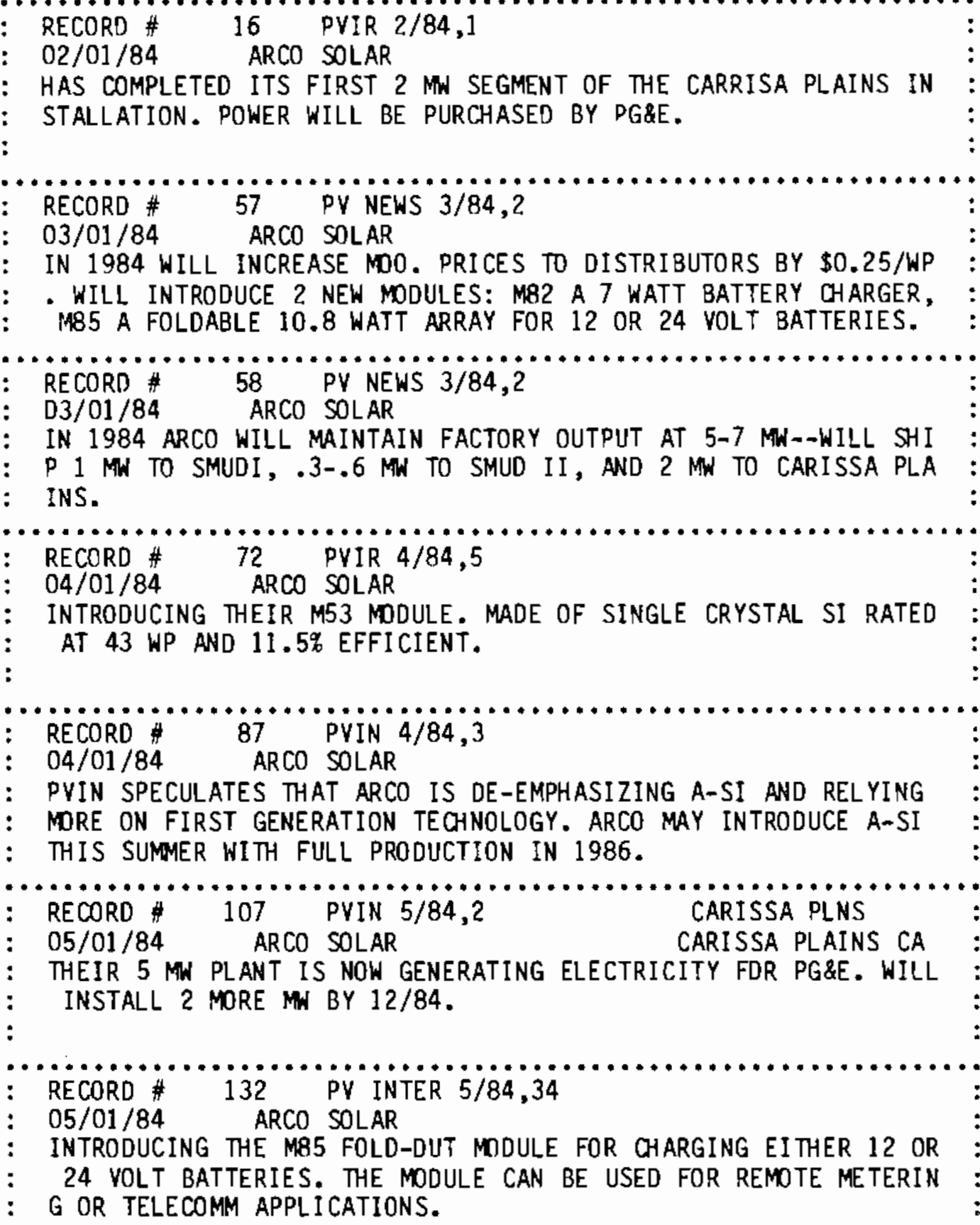


1984 PV EVENTS

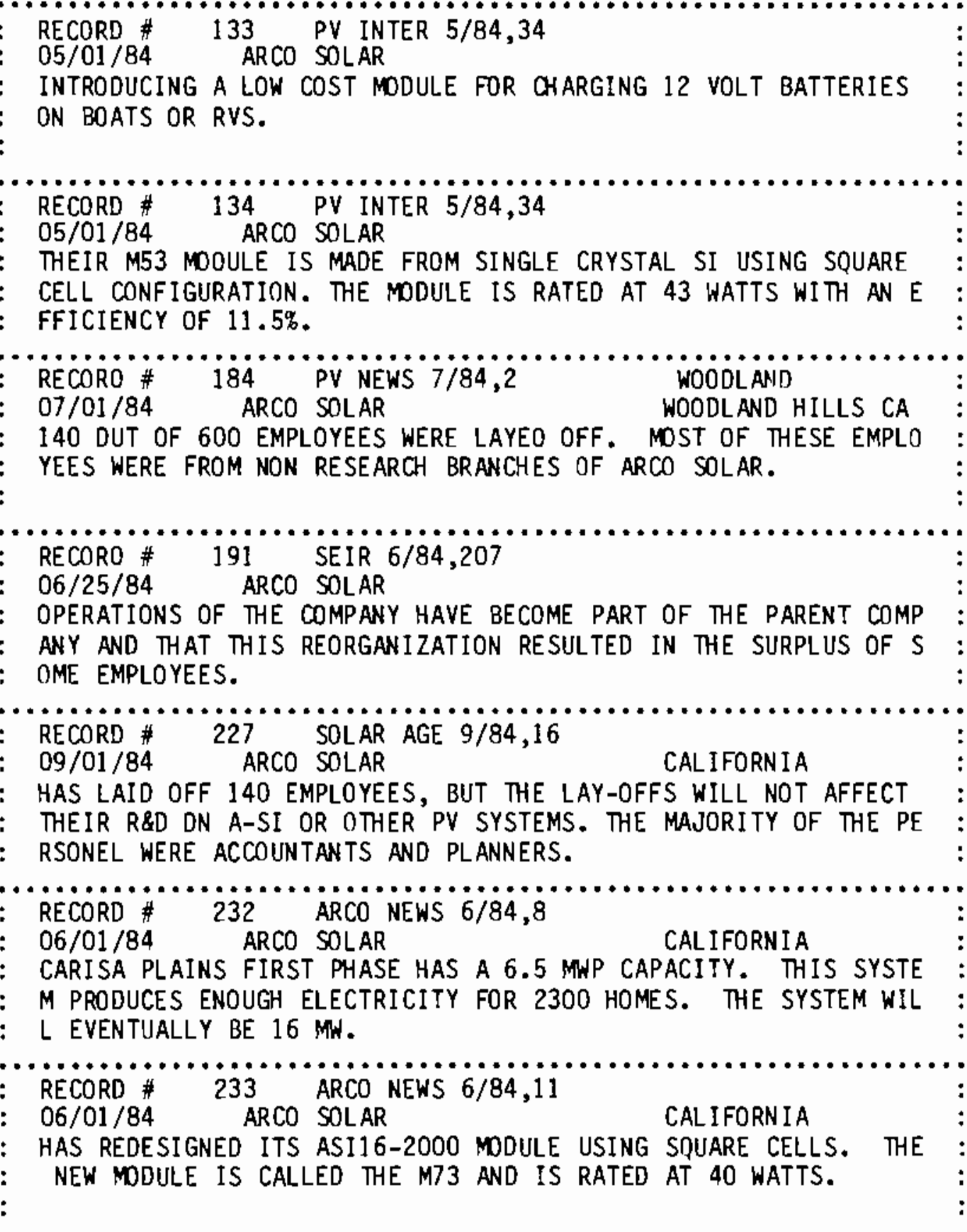


1984 PV EVENTS

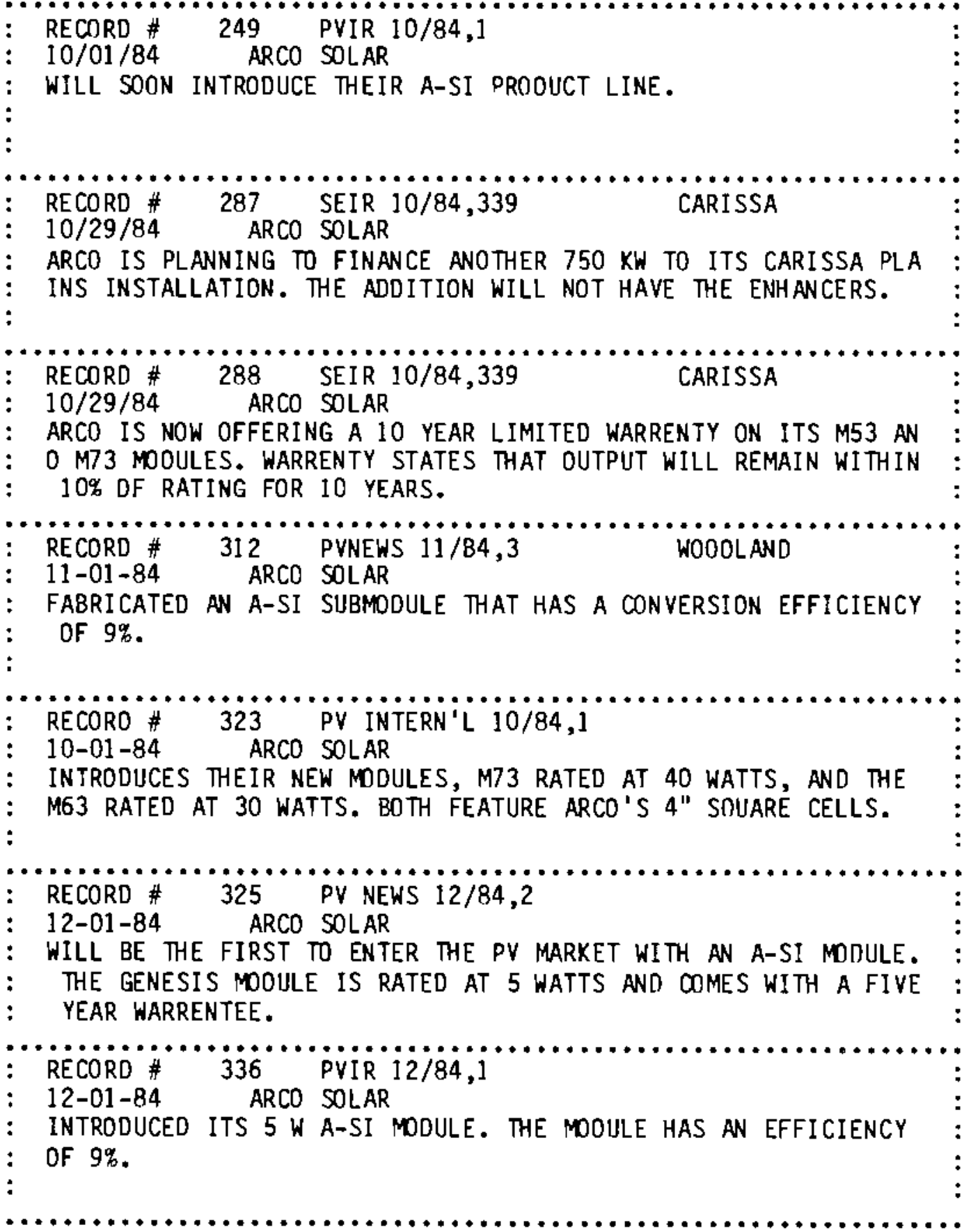




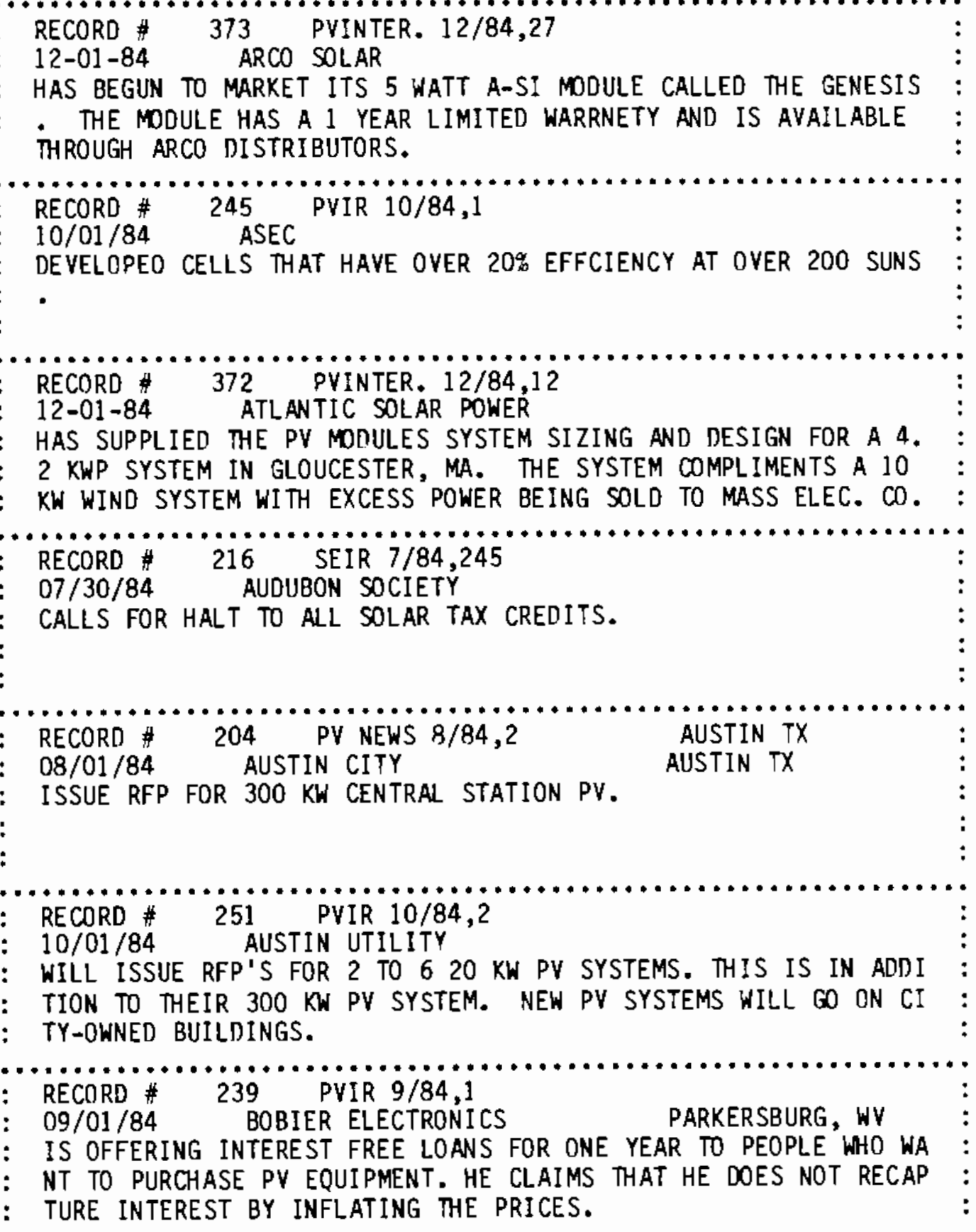


1984 PV EVENTS

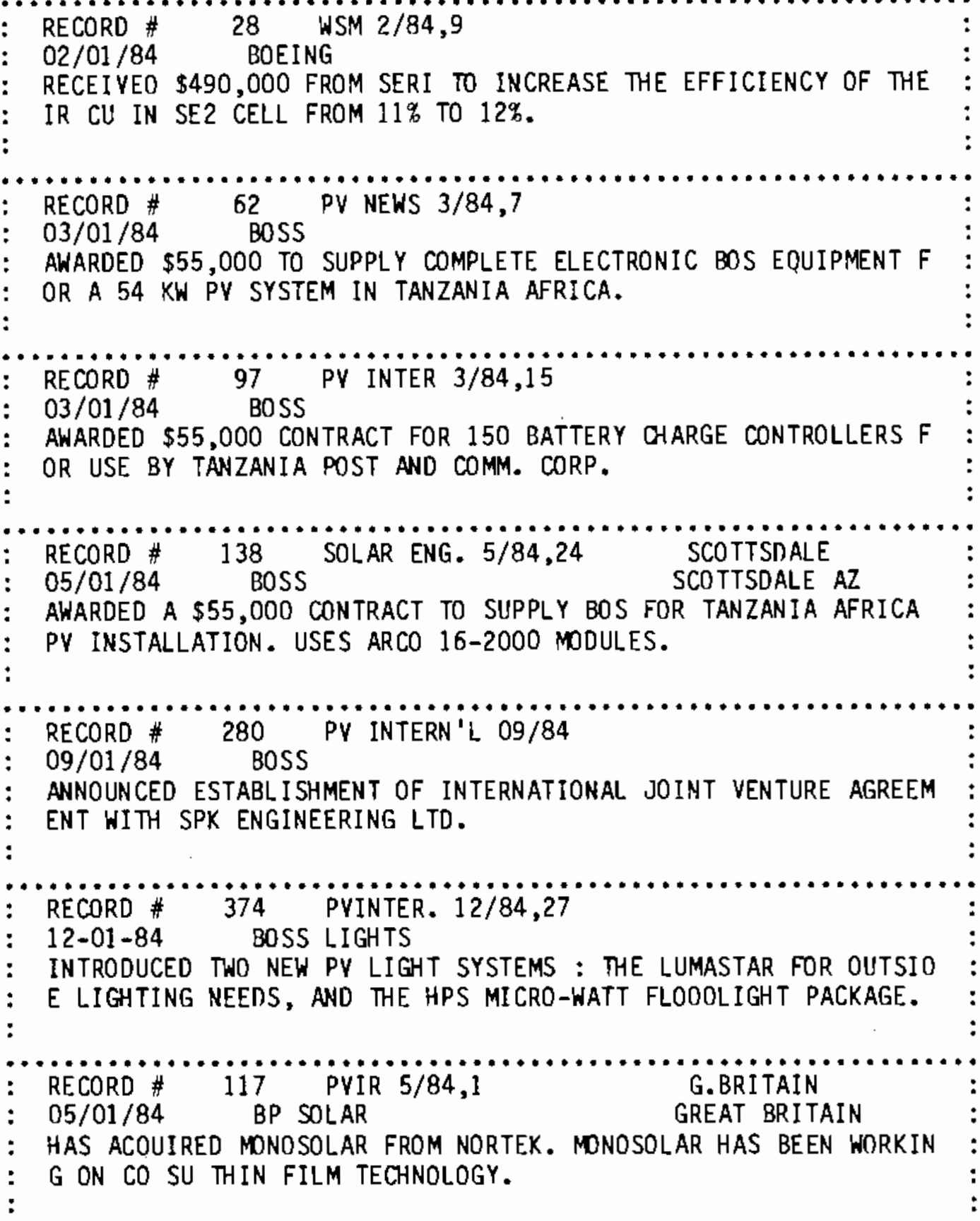


1984 PV EVENTS

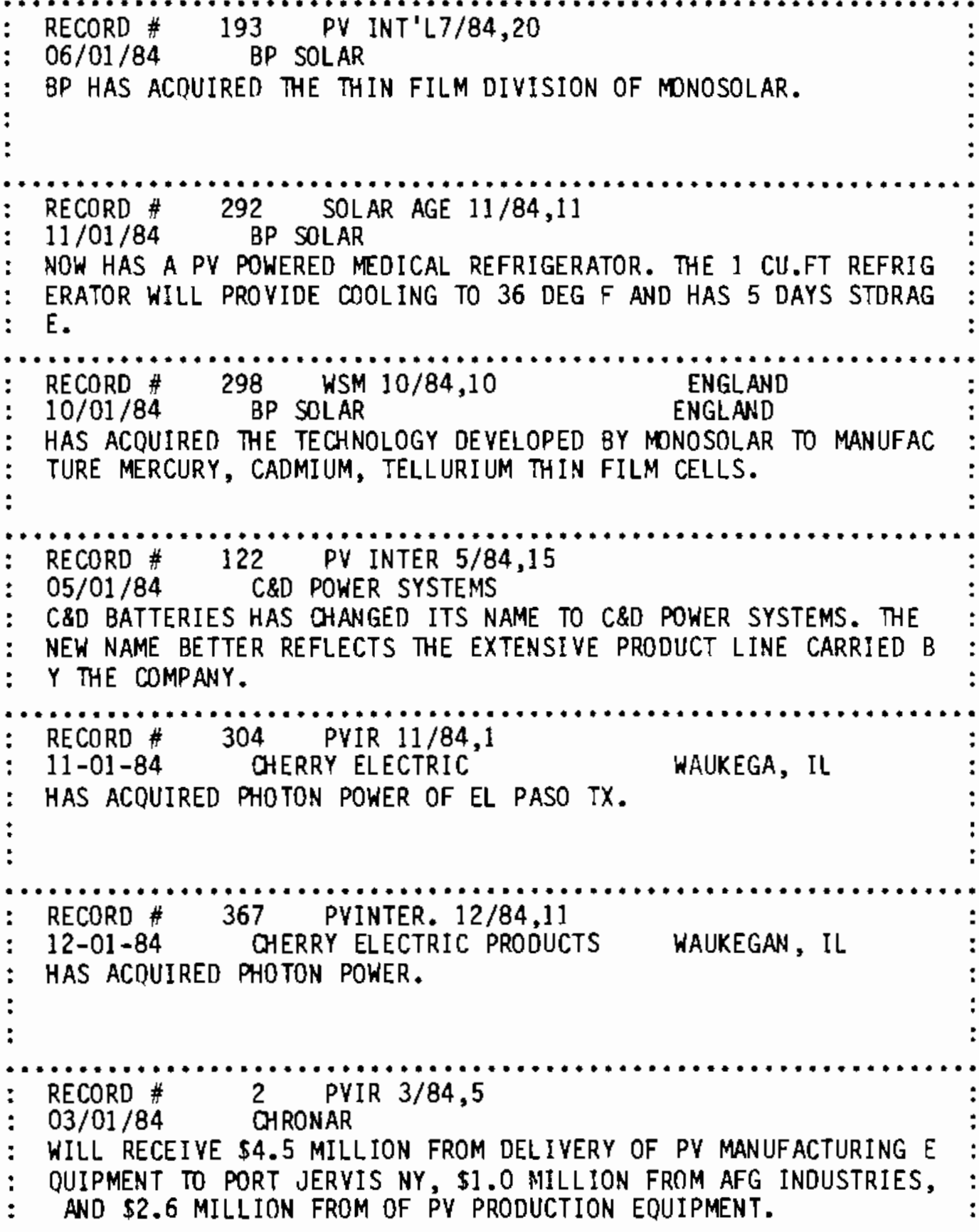




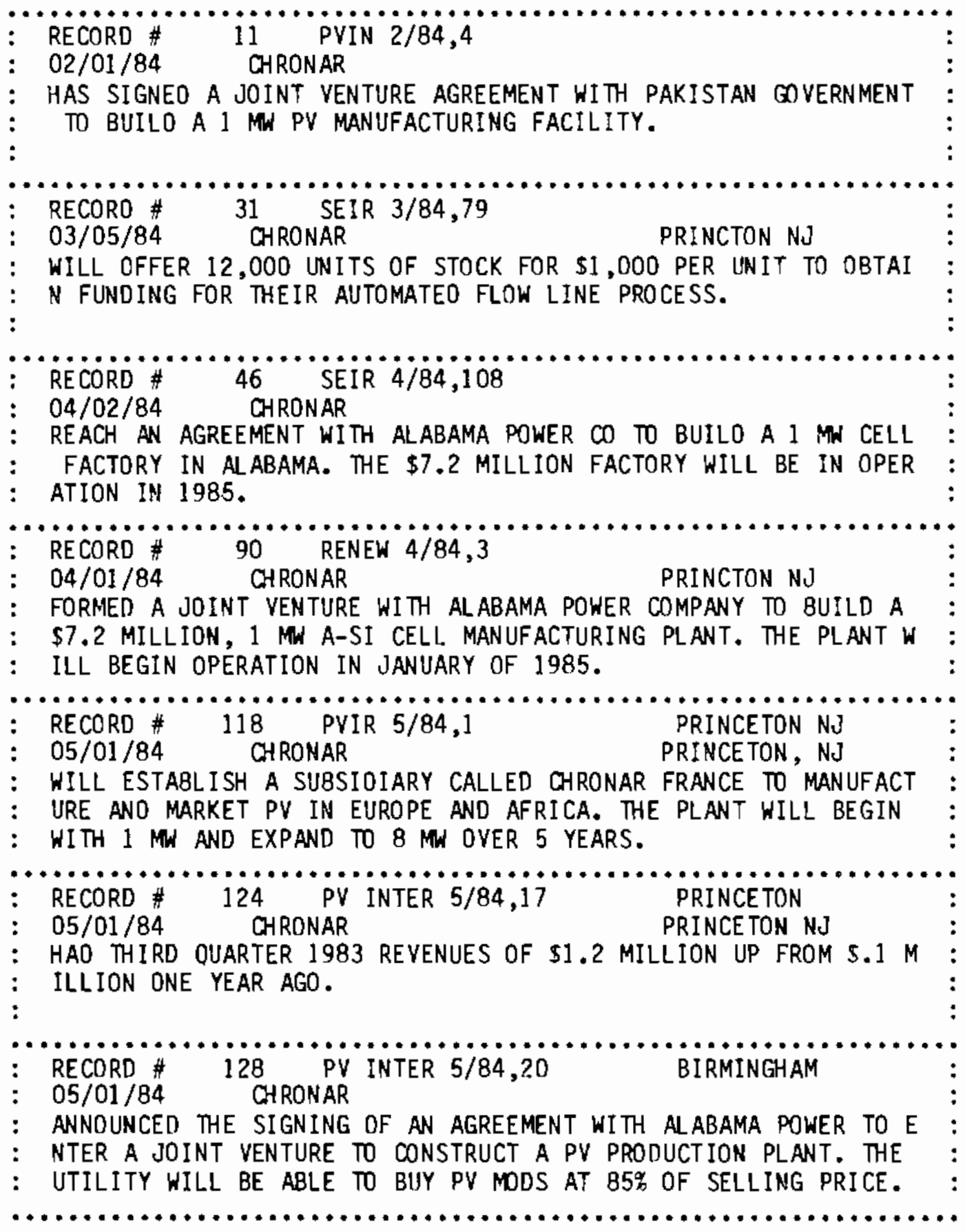


1984 PV EVENTS

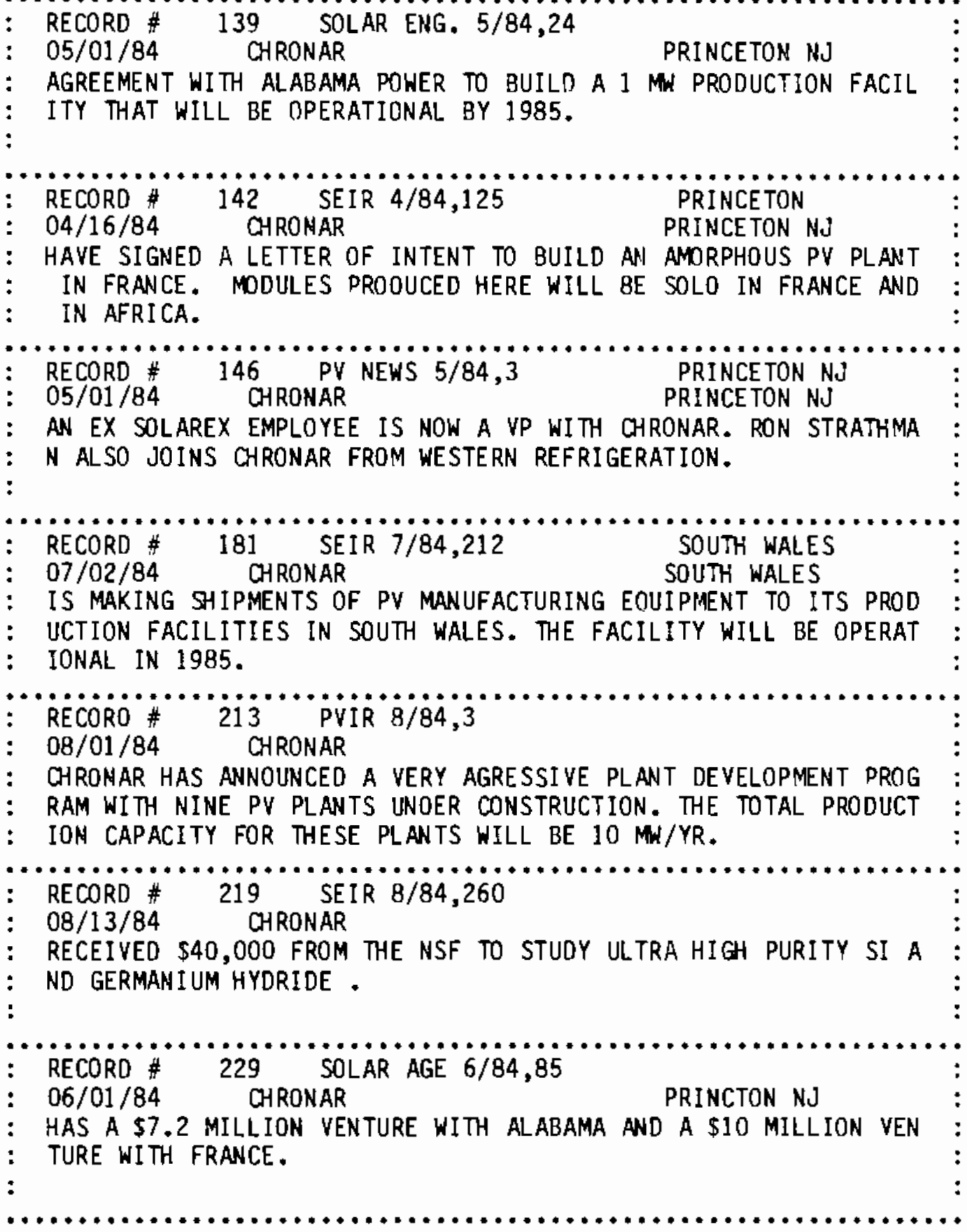




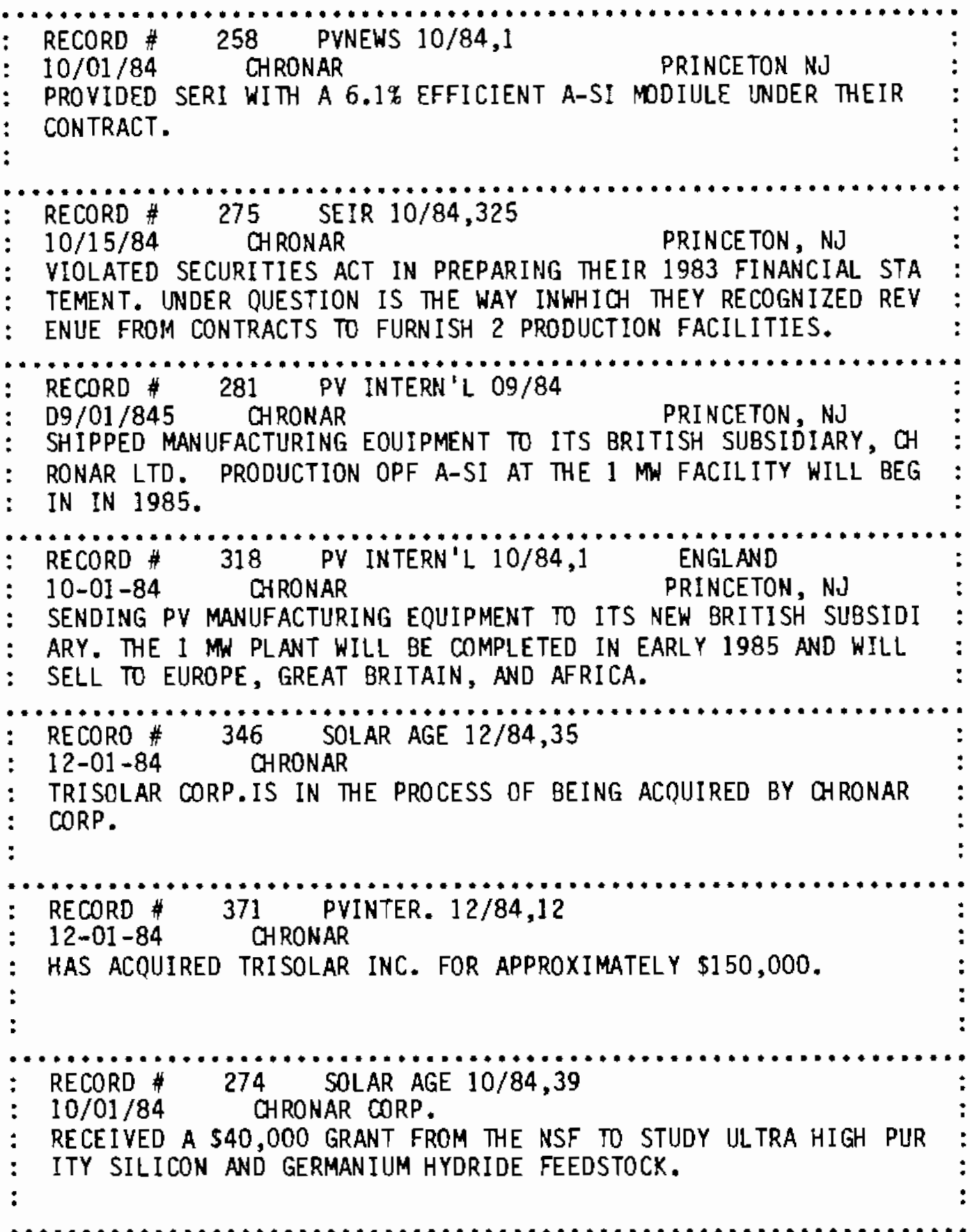




\section{PV EVENTS}

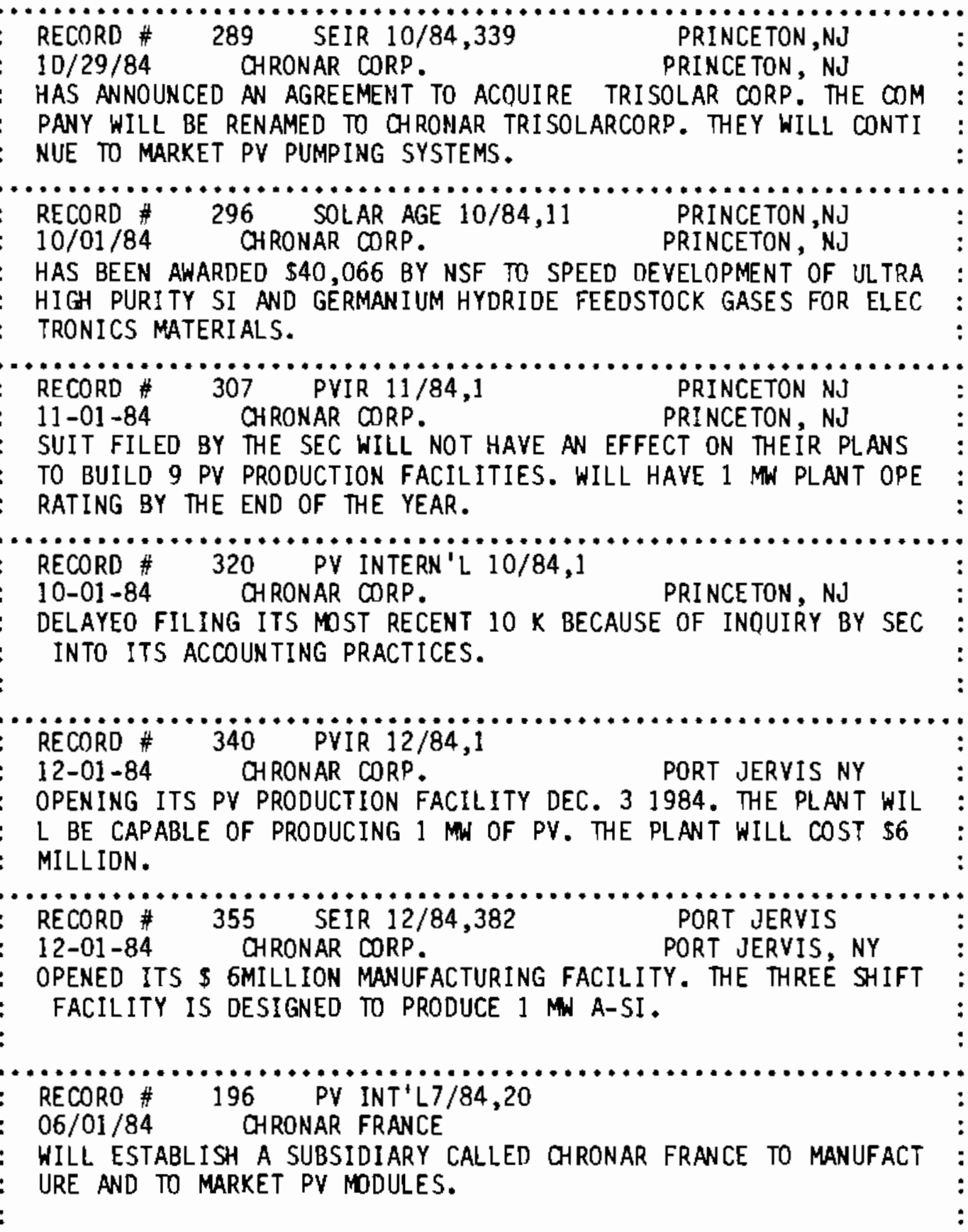




\section{PV EVENTS}

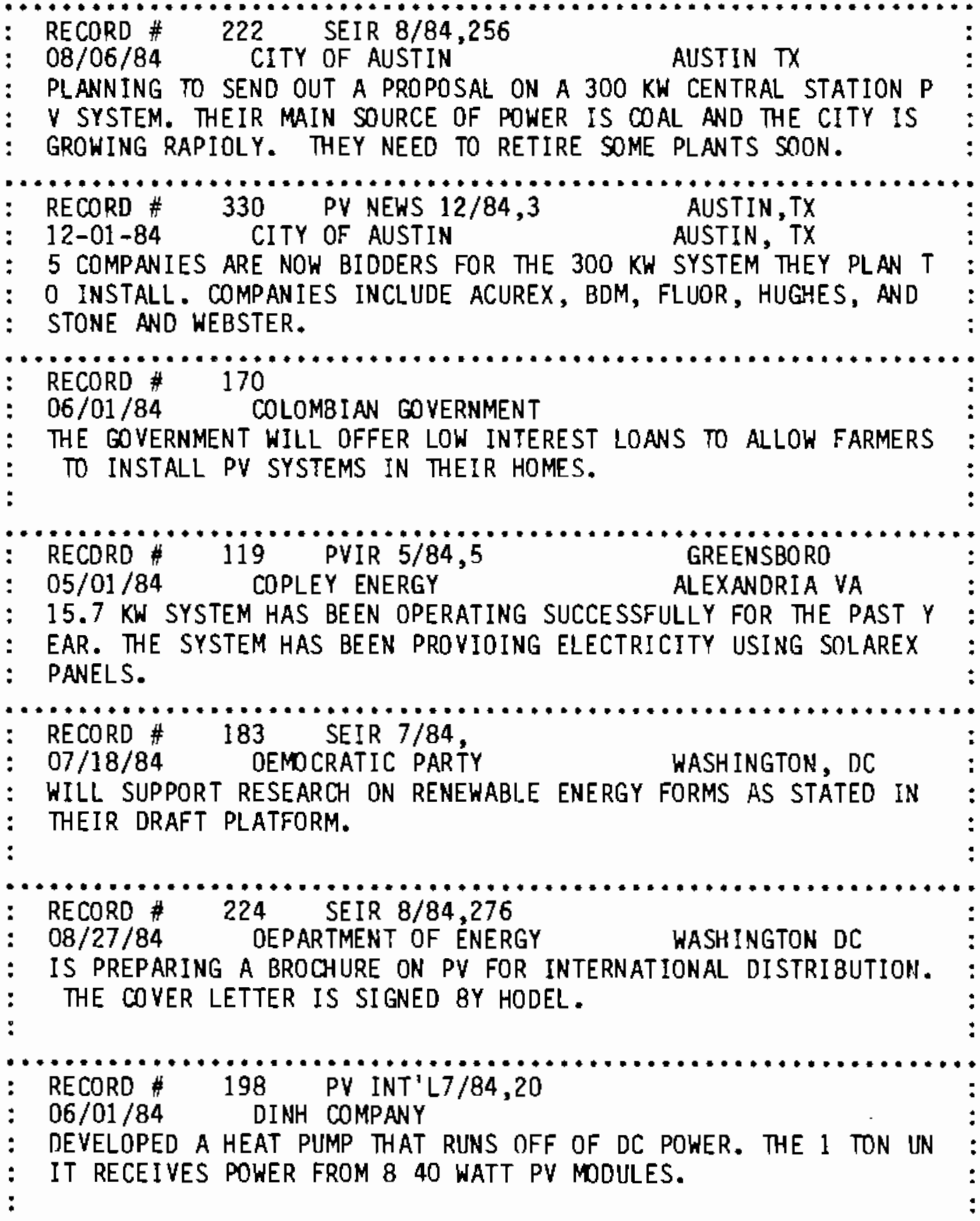


1984 PV EVENTS

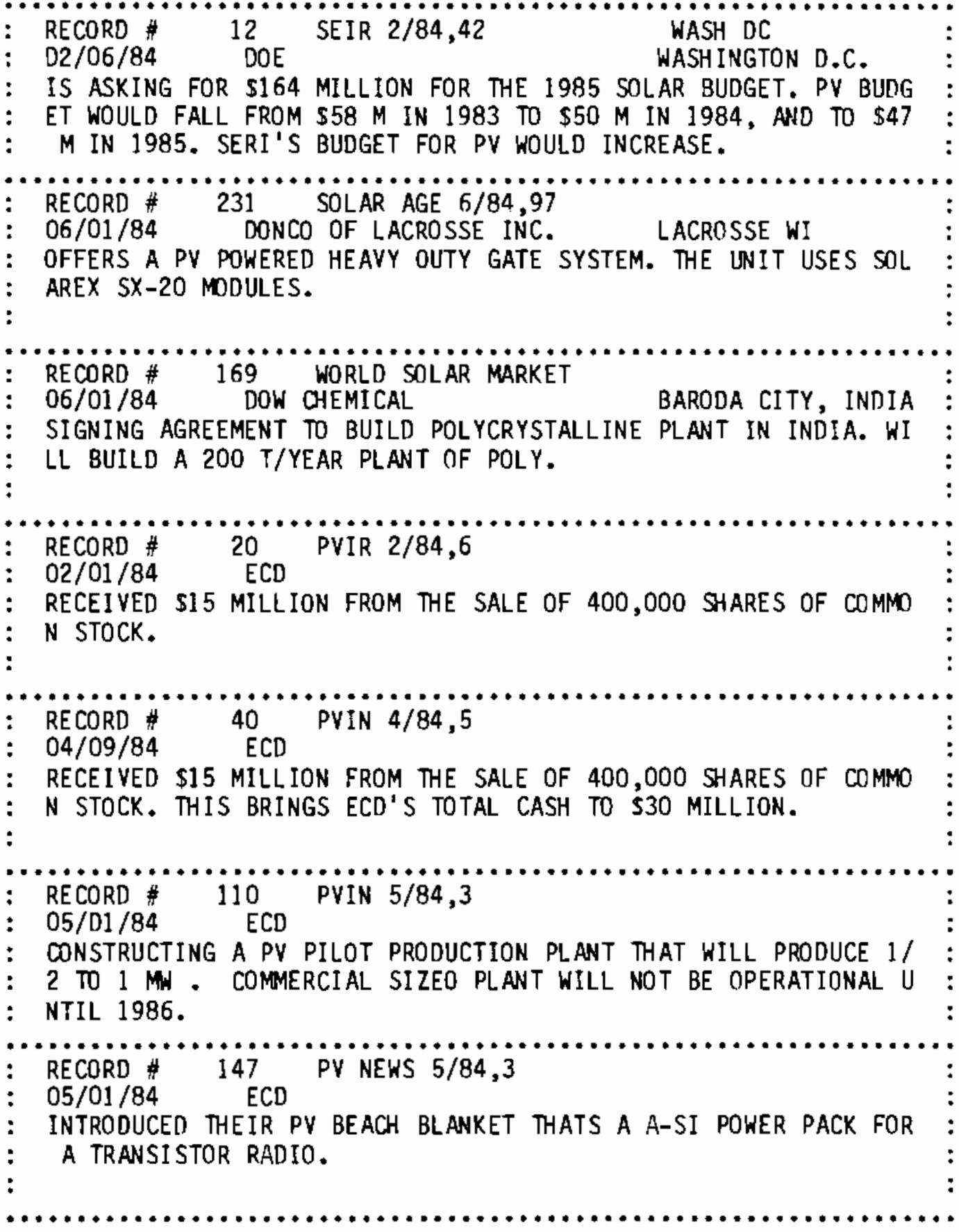


1984 PV EVENTS

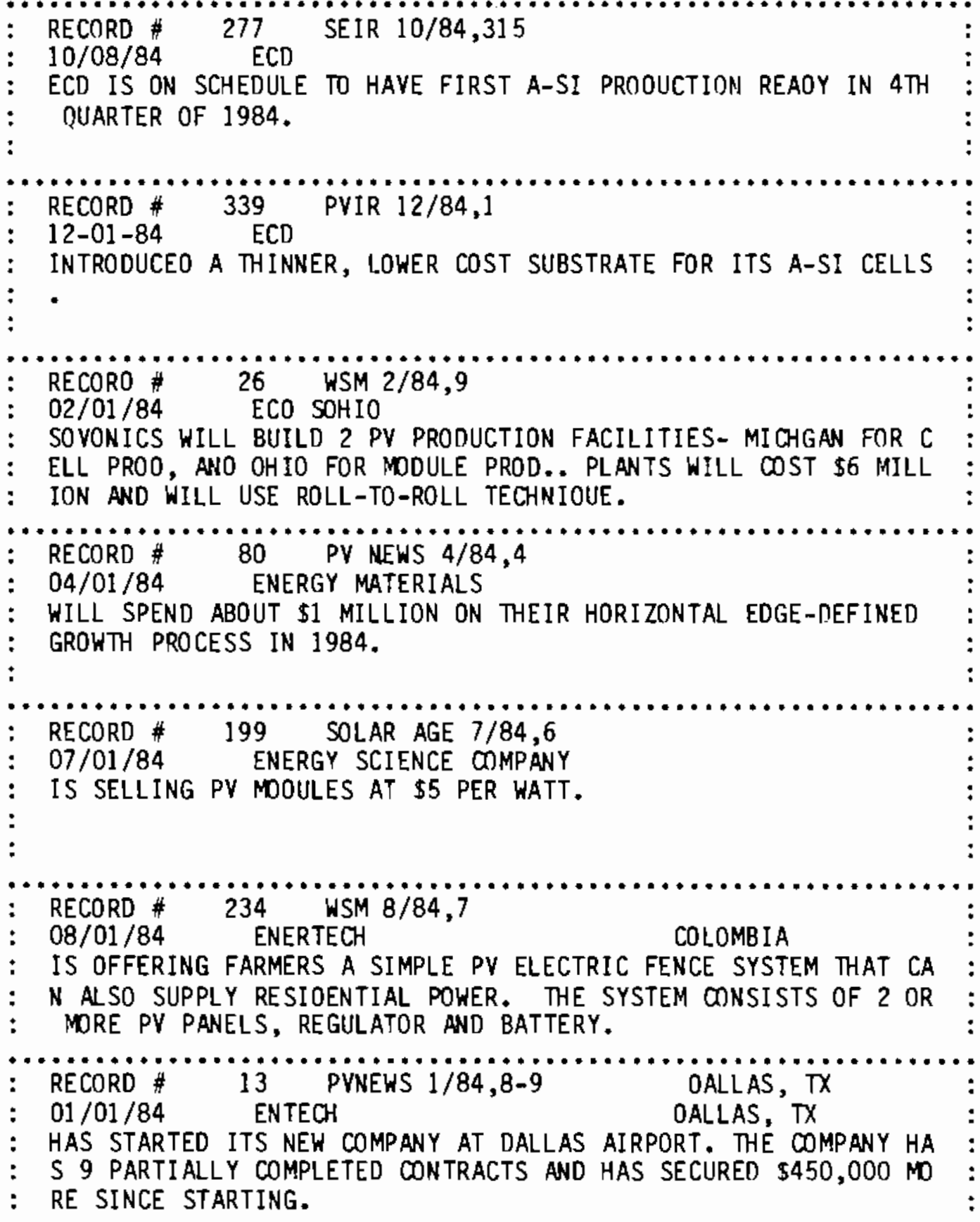




\section{PV EVENTS}

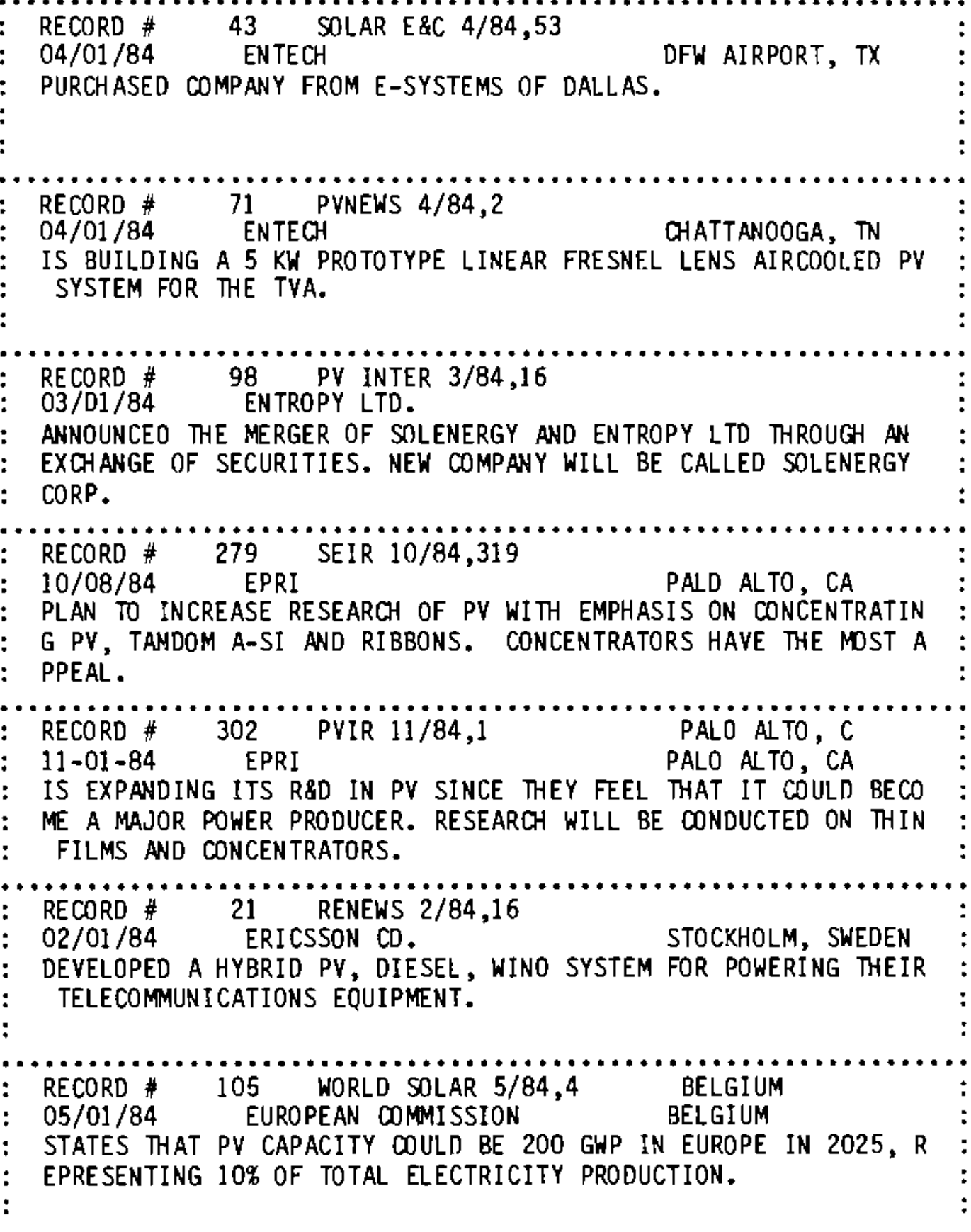


1984 PV EVENTS

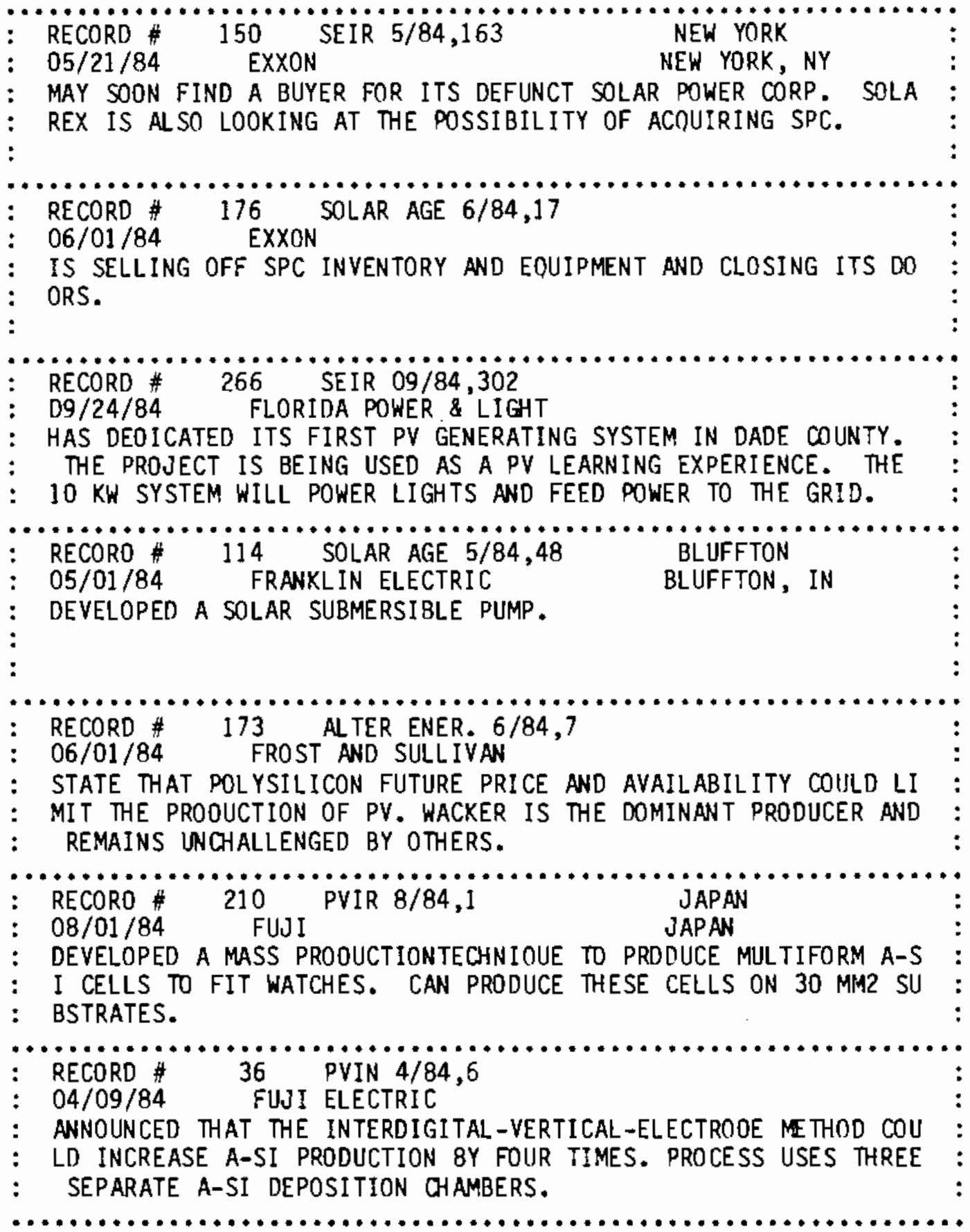




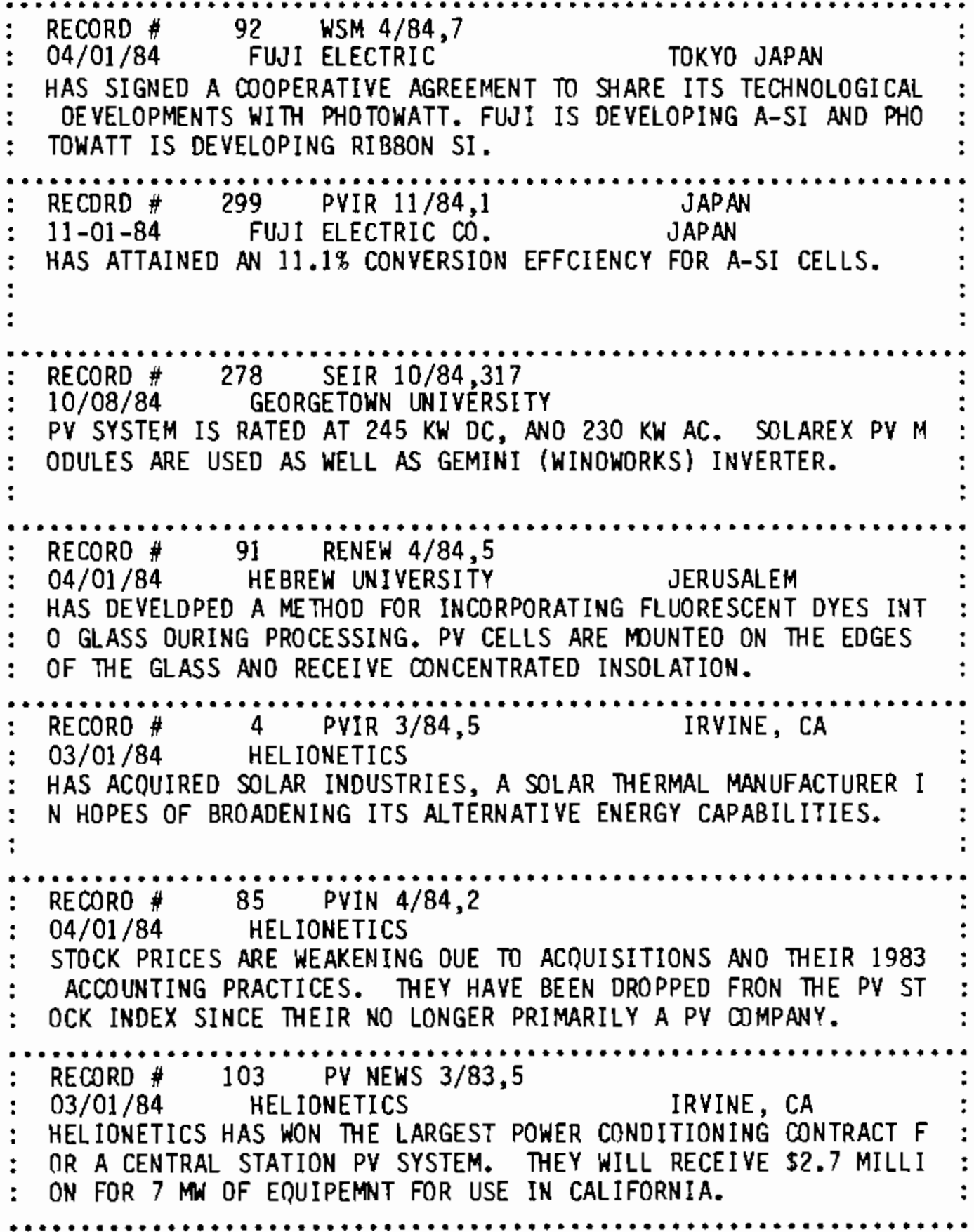

PAGE NO. 
1984 PV EVENTS

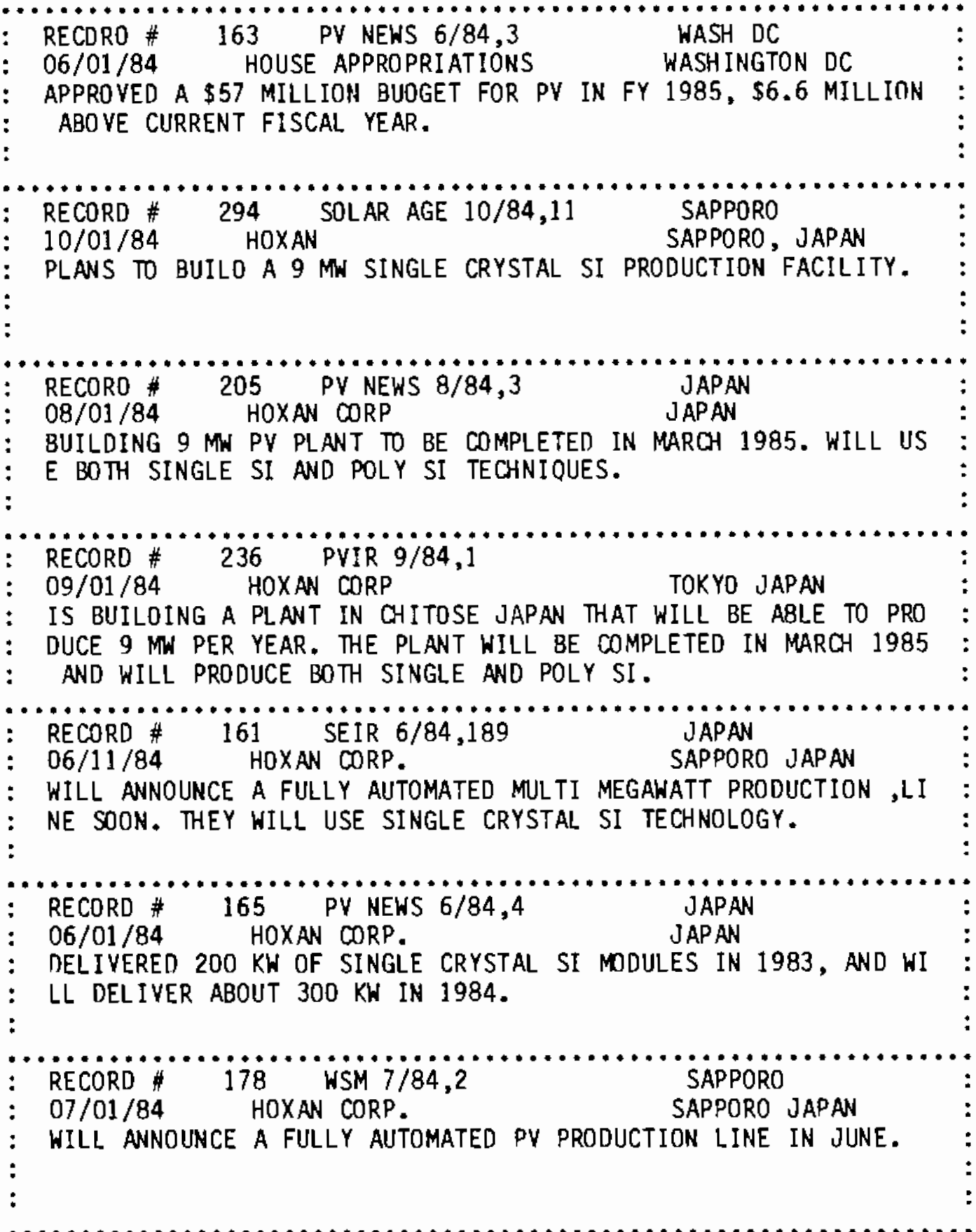




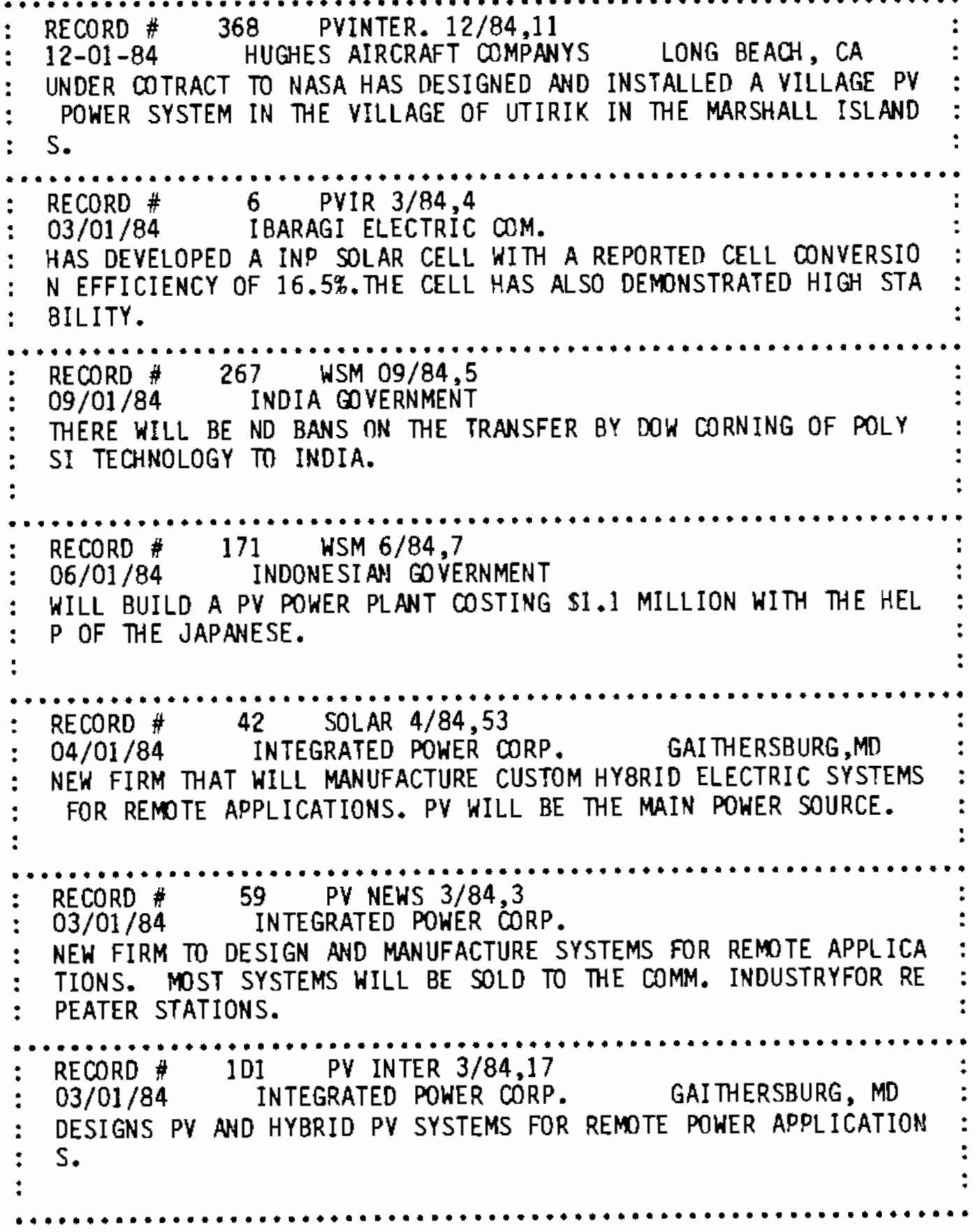


1984 PV EVENTS

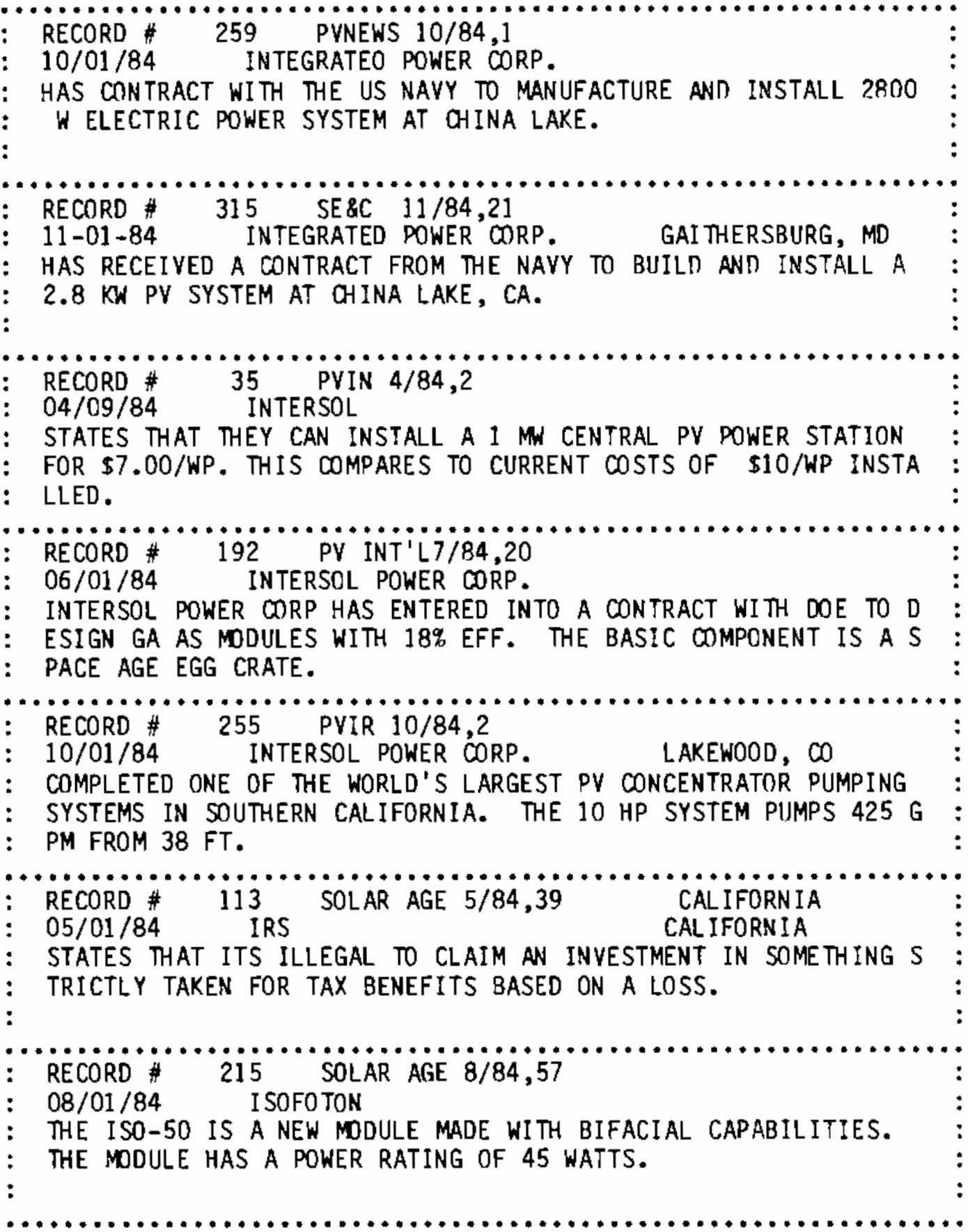




\section{PV EVENTS}

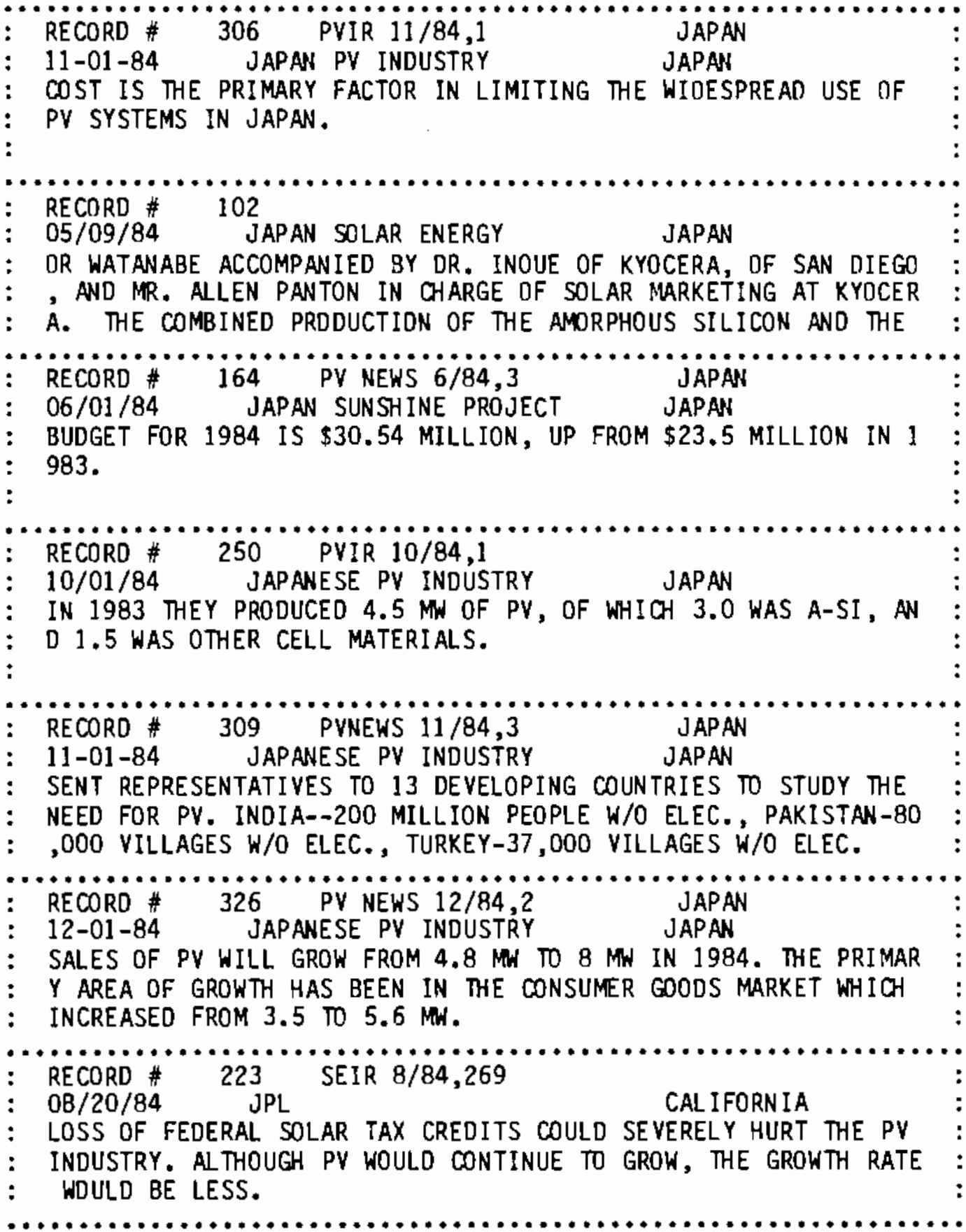




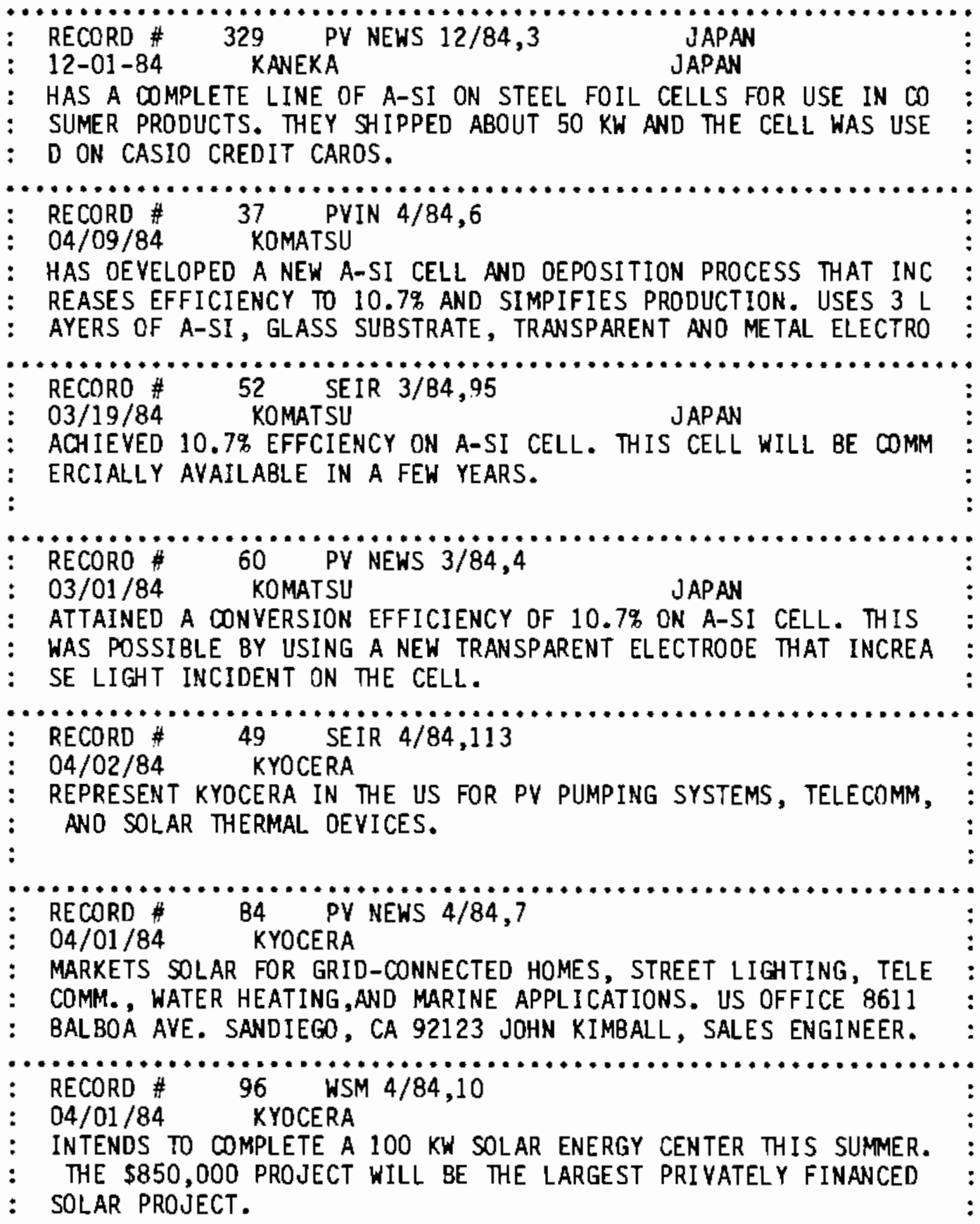

PAGE NO. 


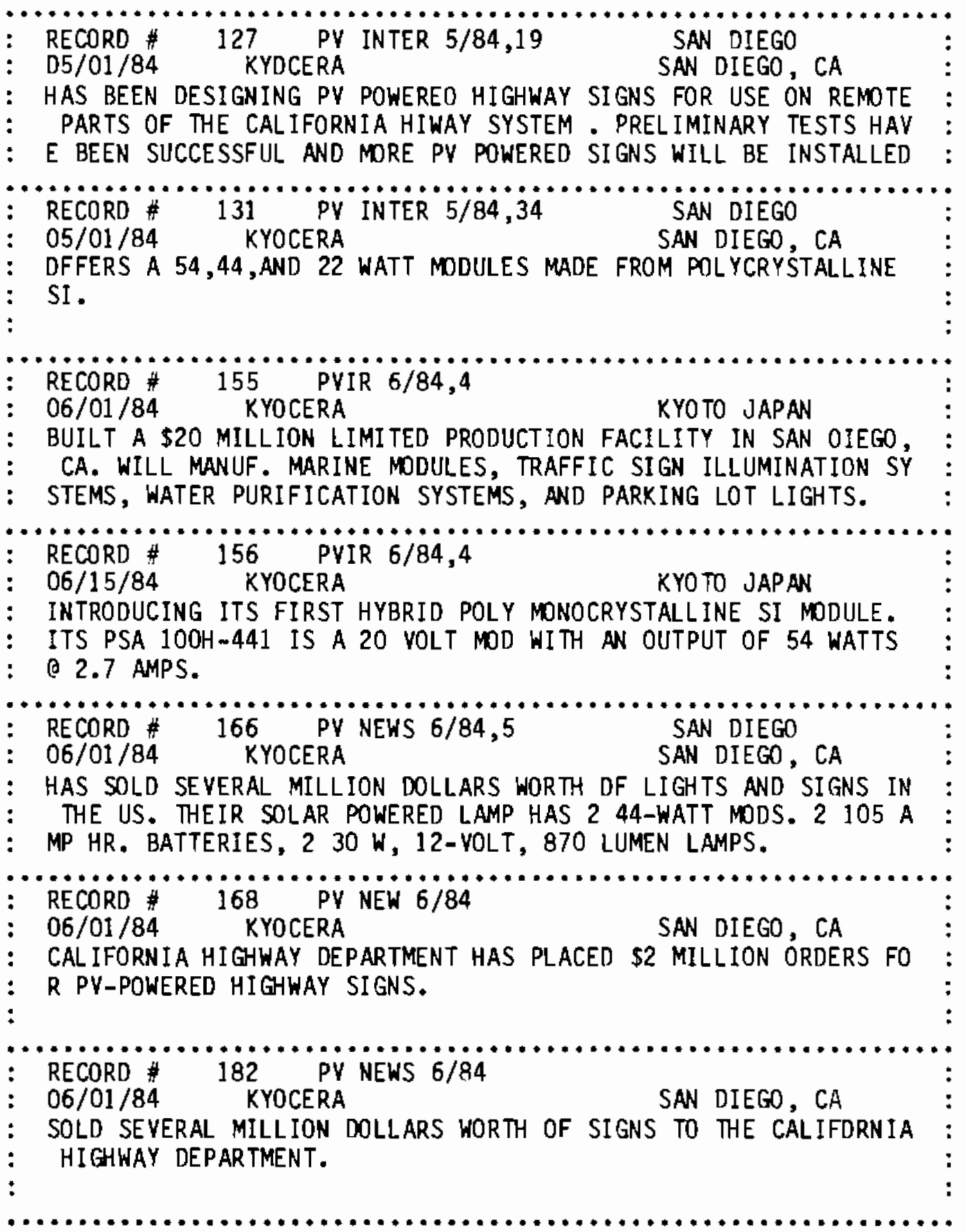




\section{PV EVENTS}

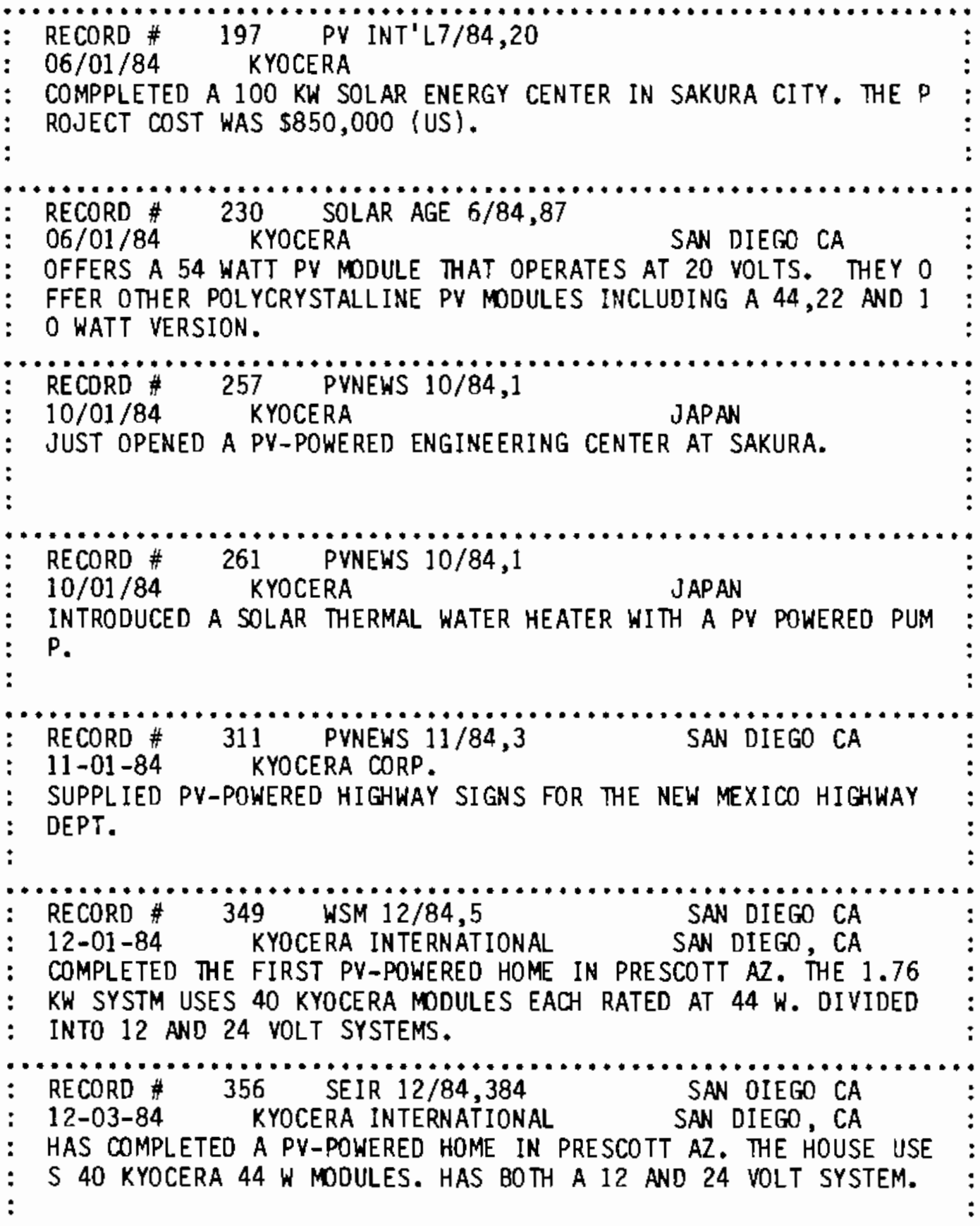




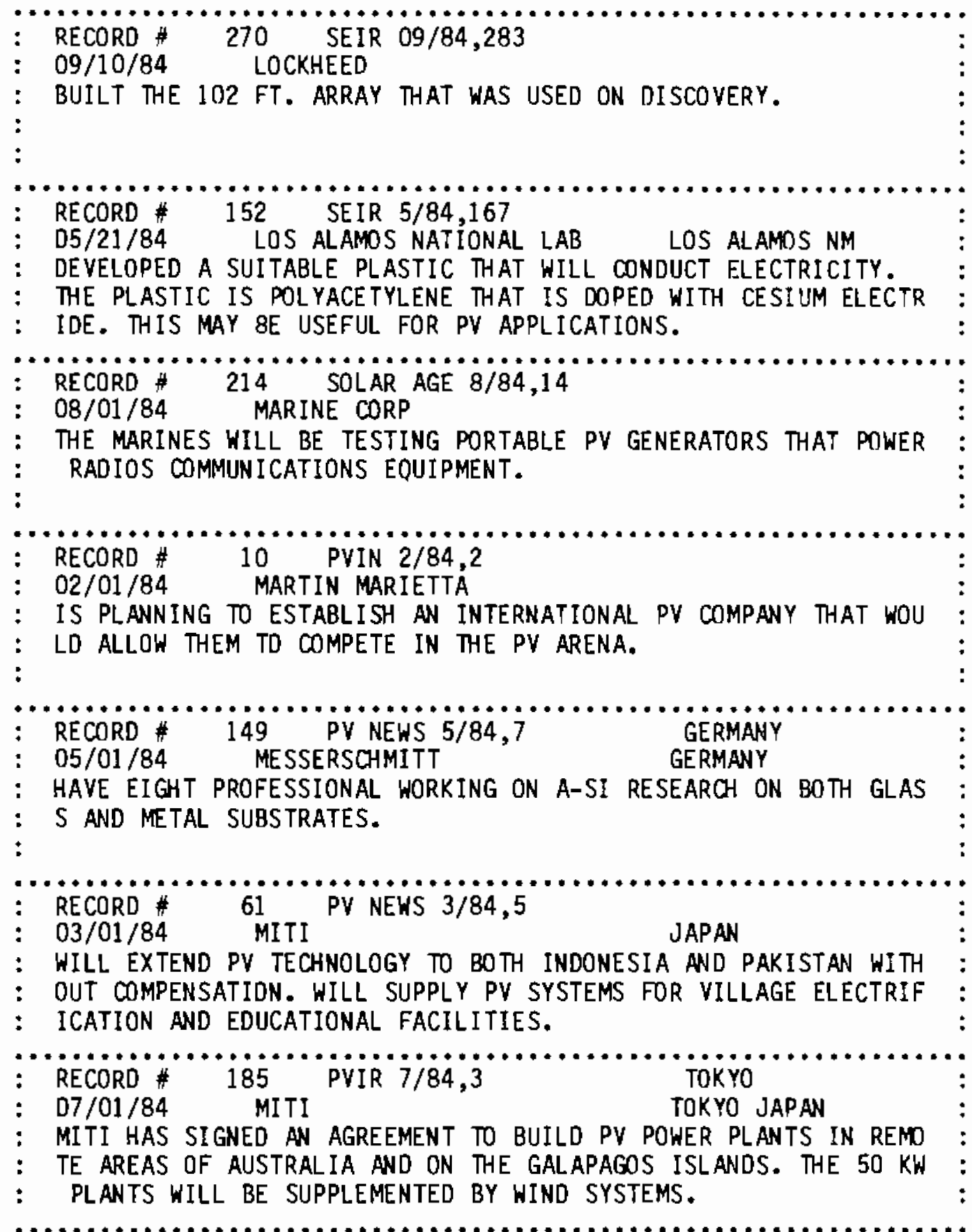




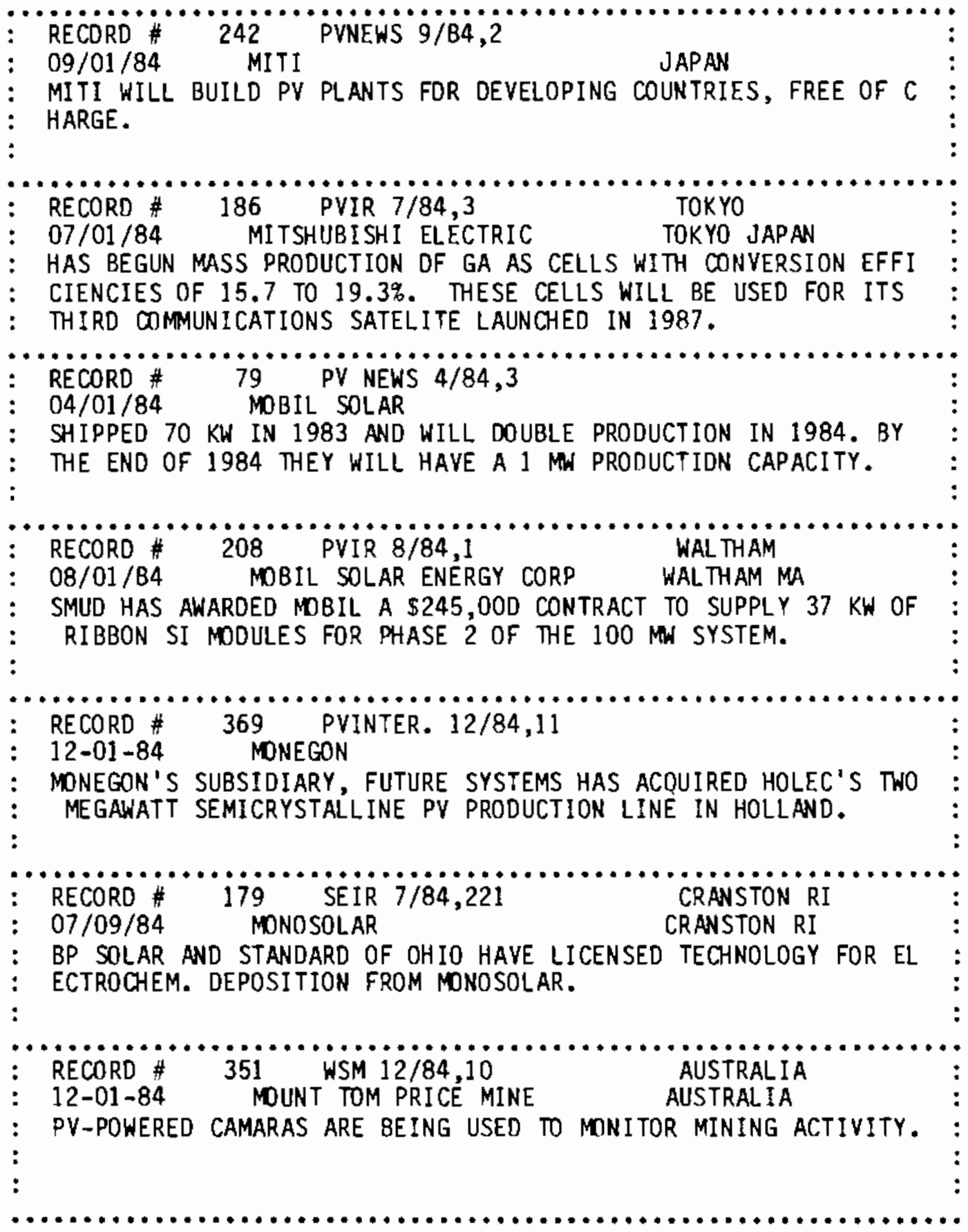




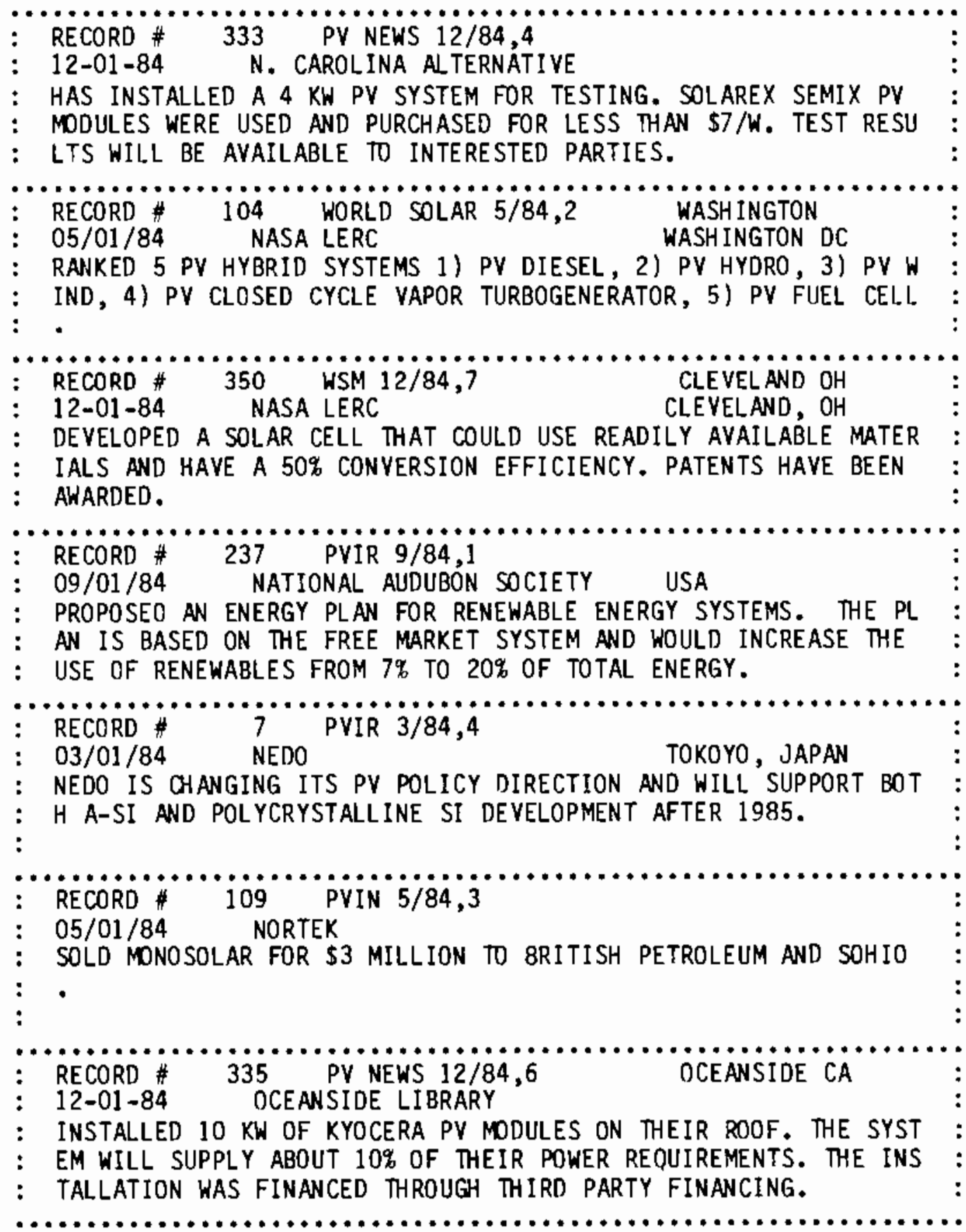




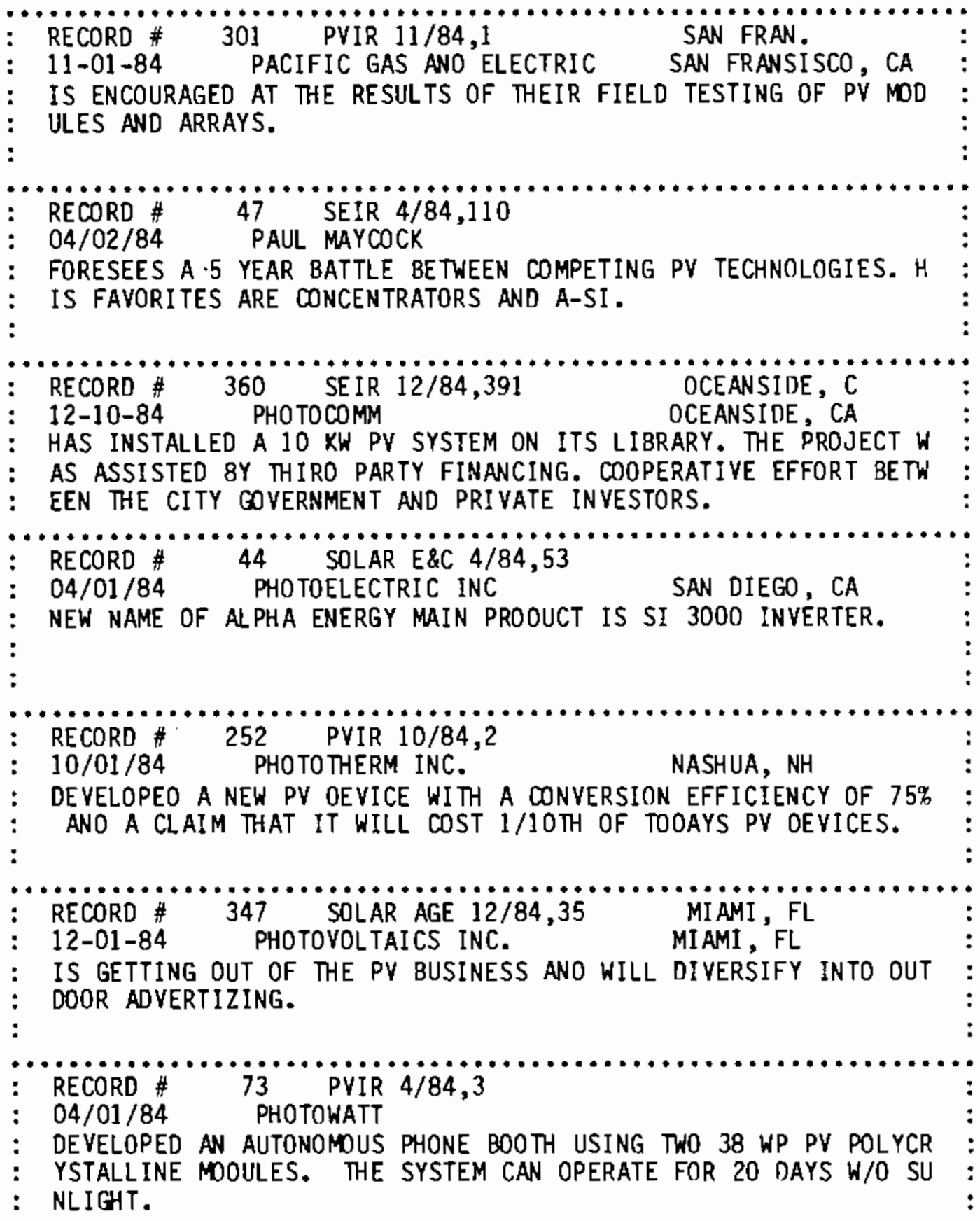


1984 PV EVENTS

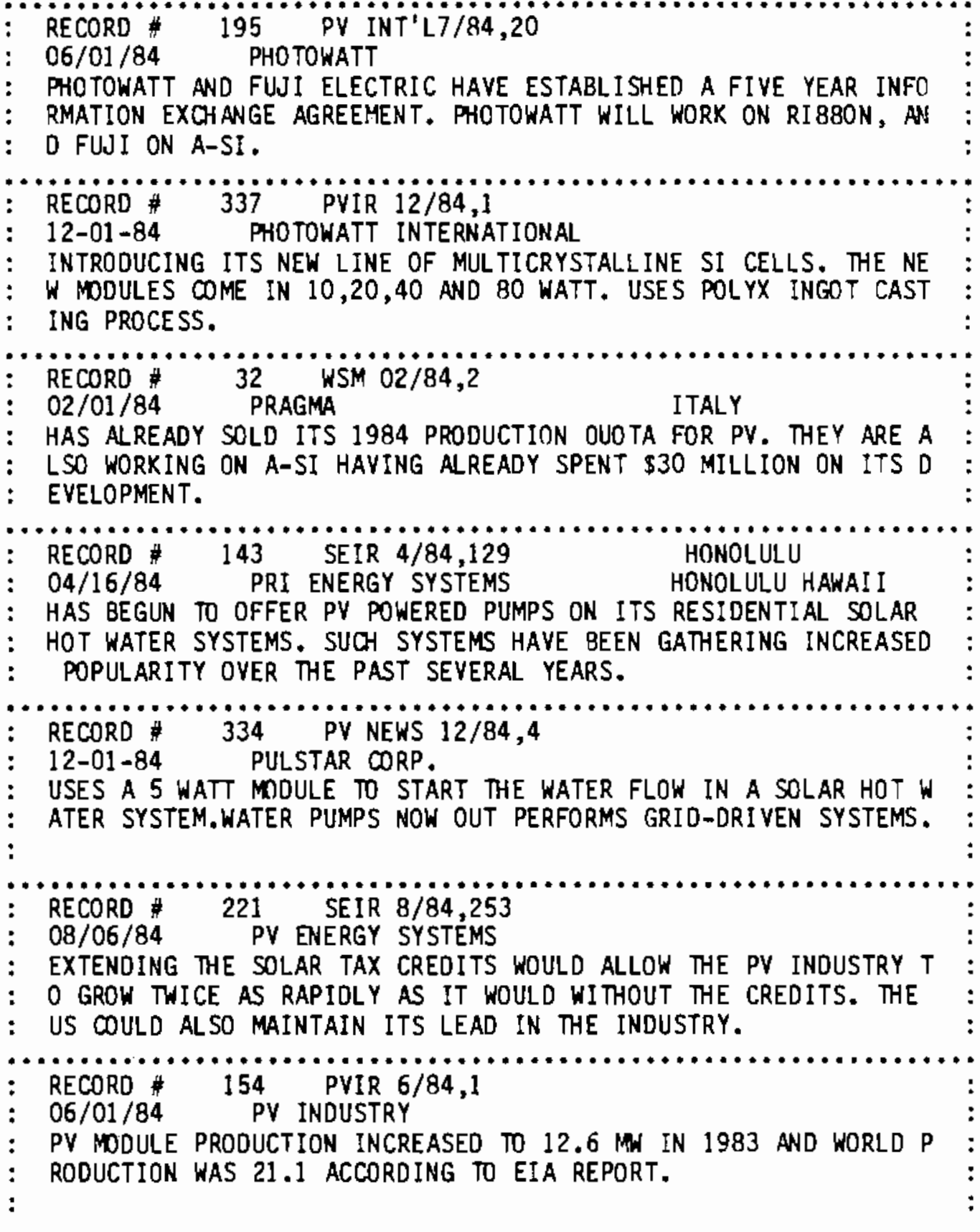




\section{PV EVENTS}

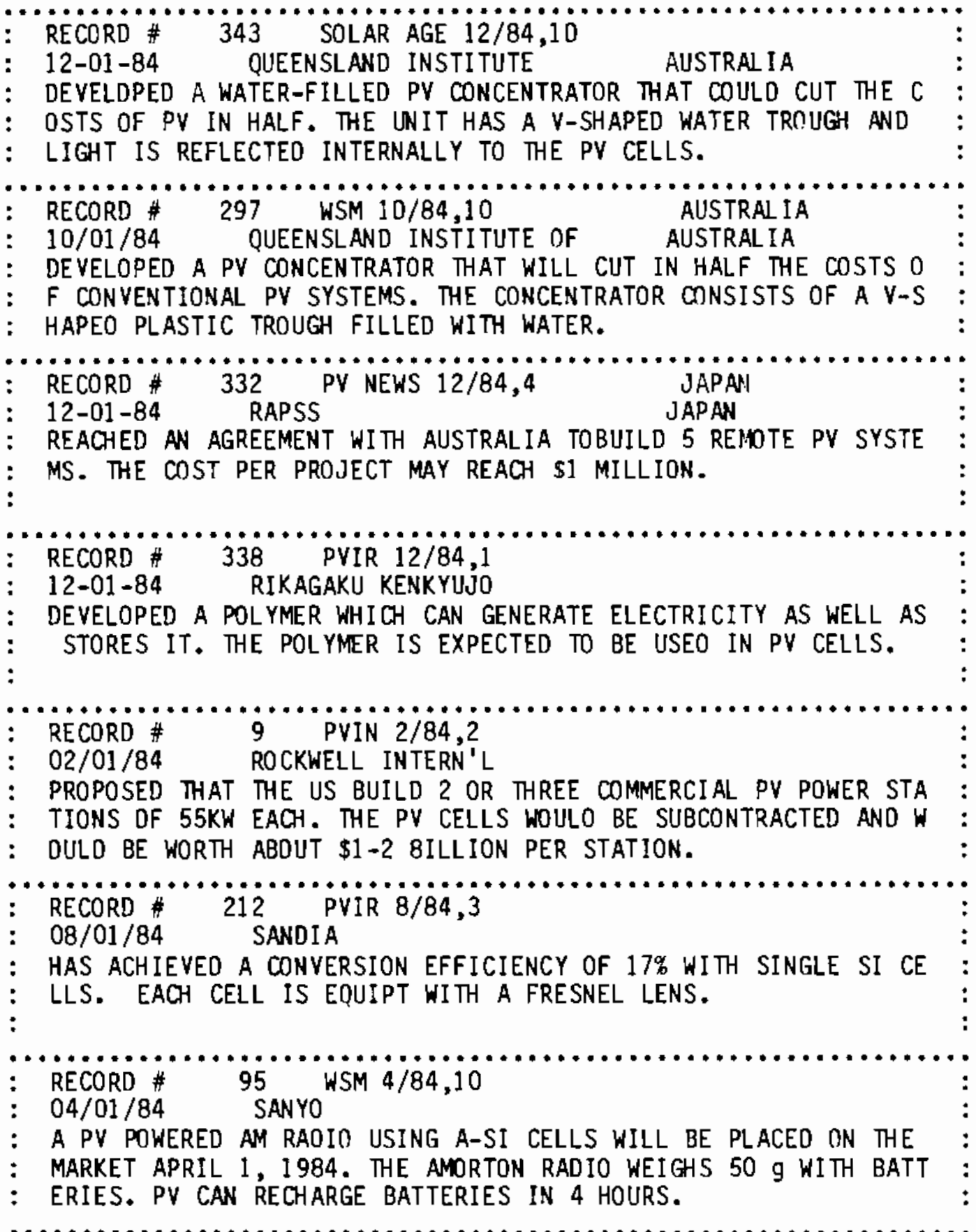




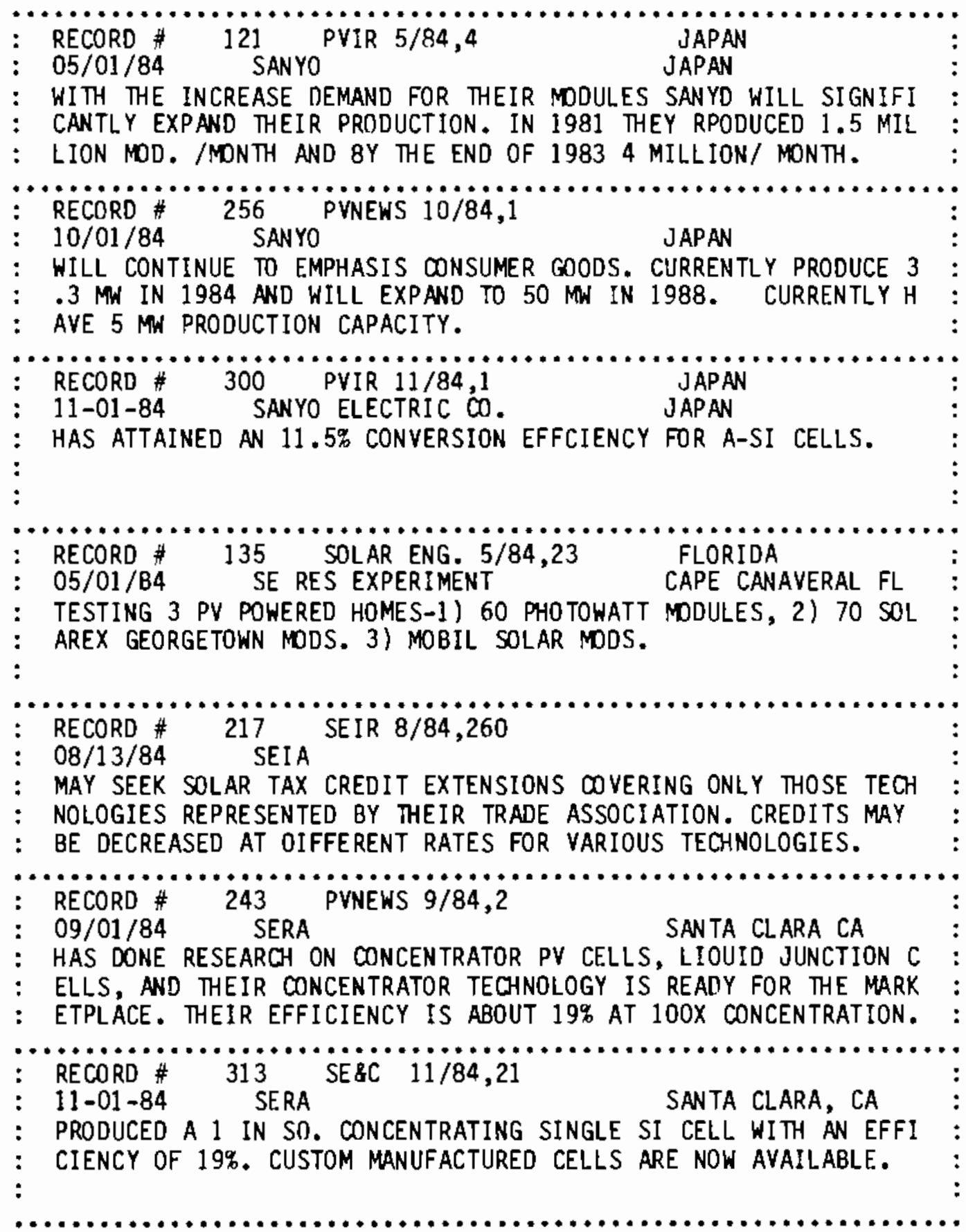




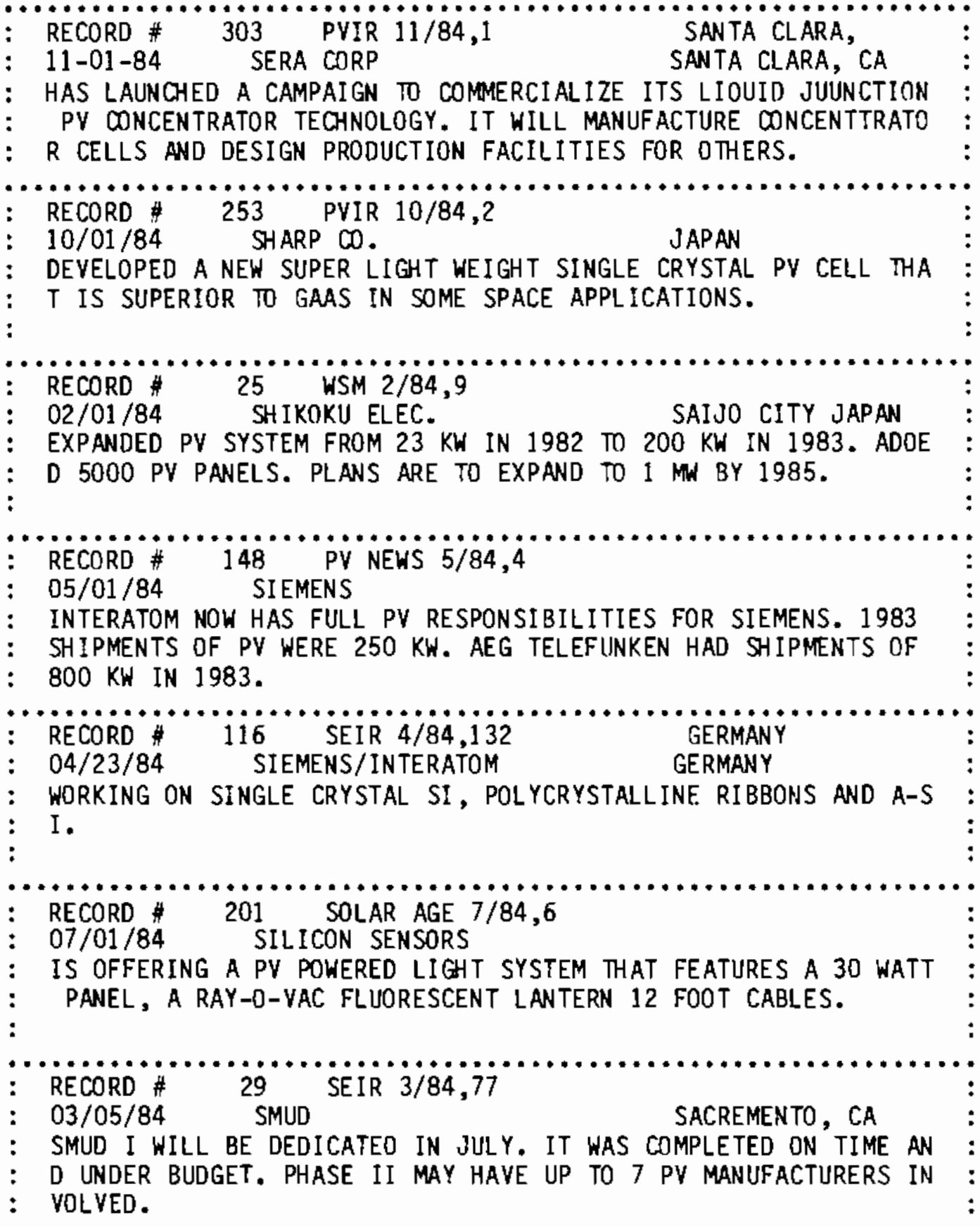




\section{PV EVENTS}

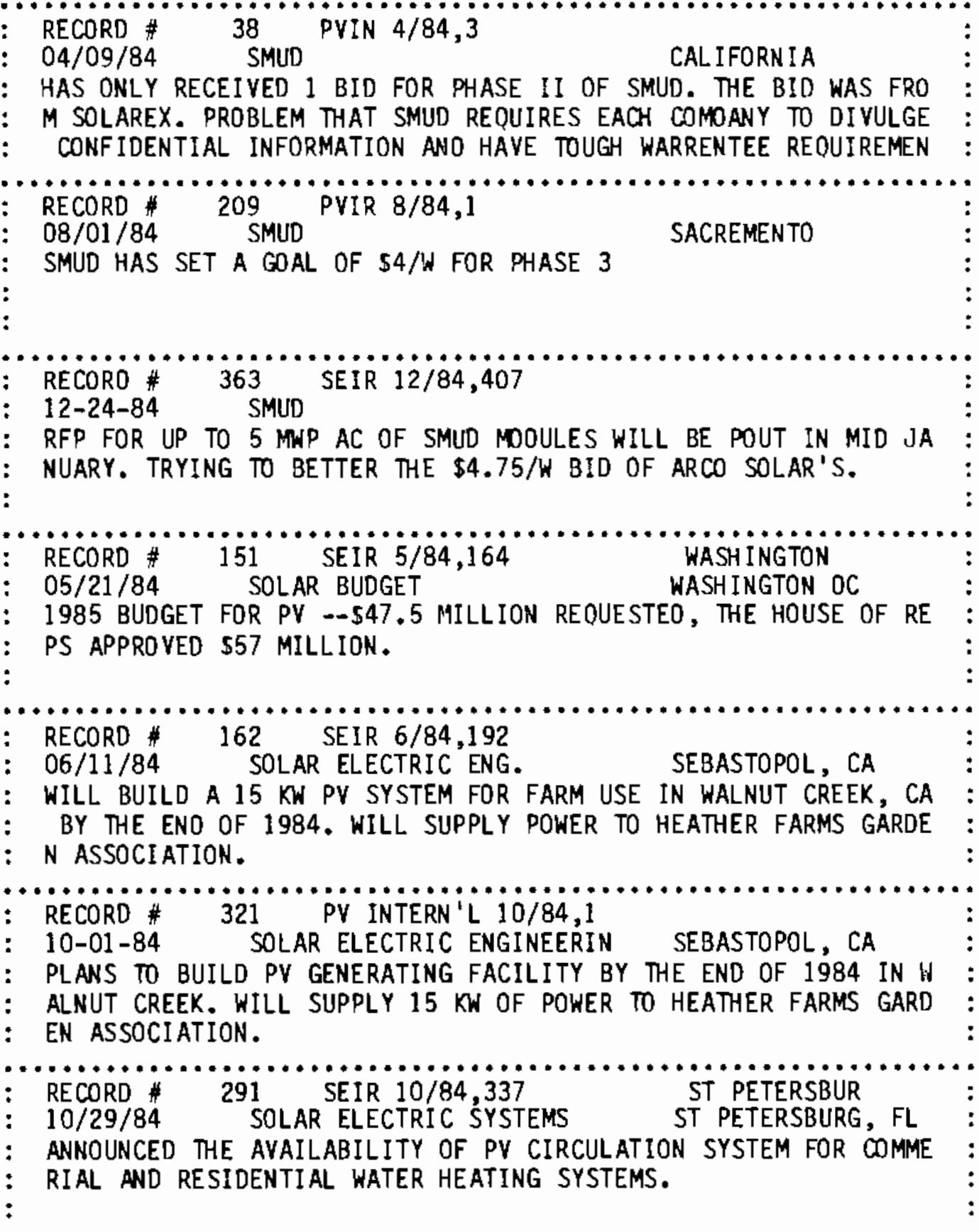


1984 PV EVENTS

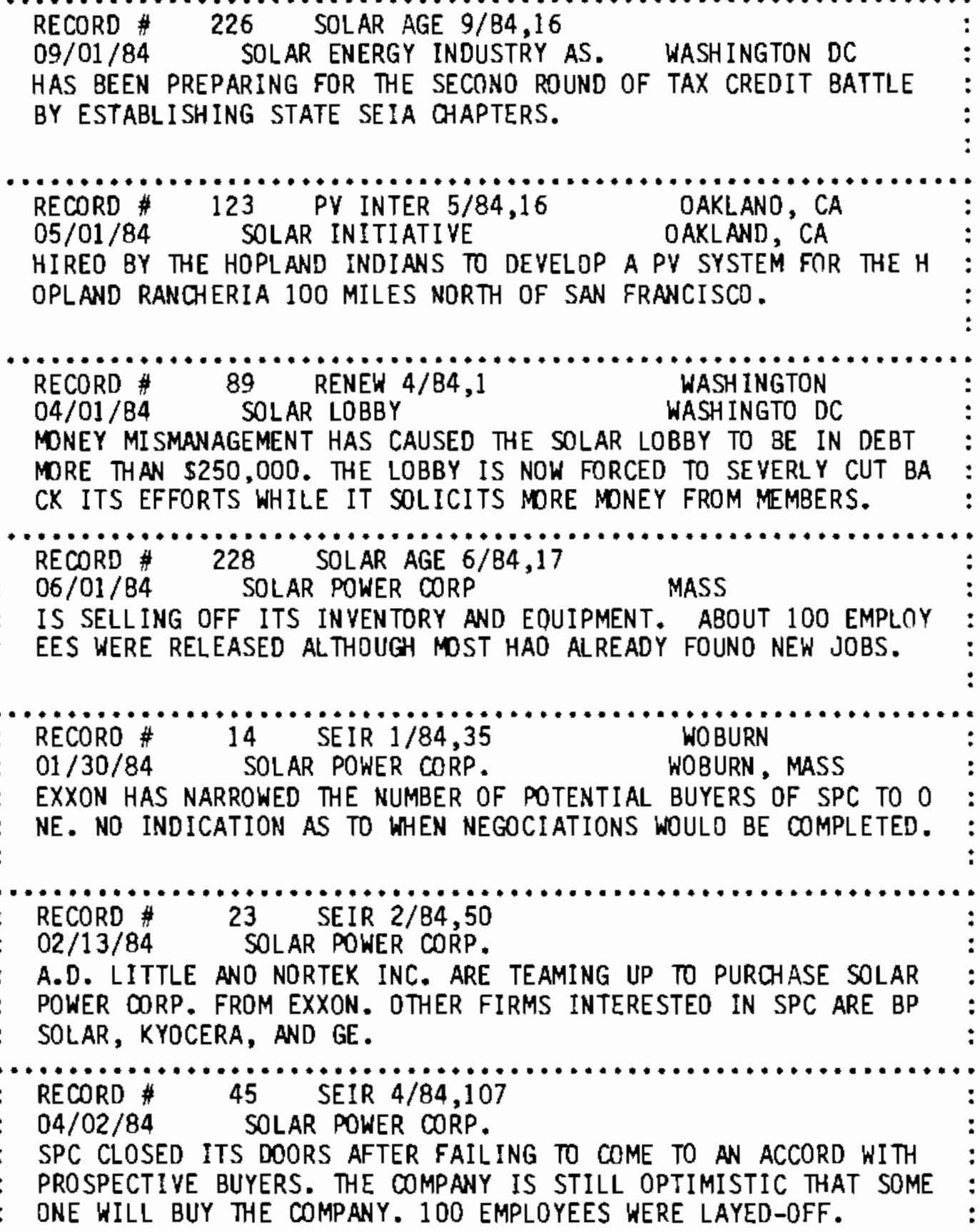




\section{PV EVENTS}

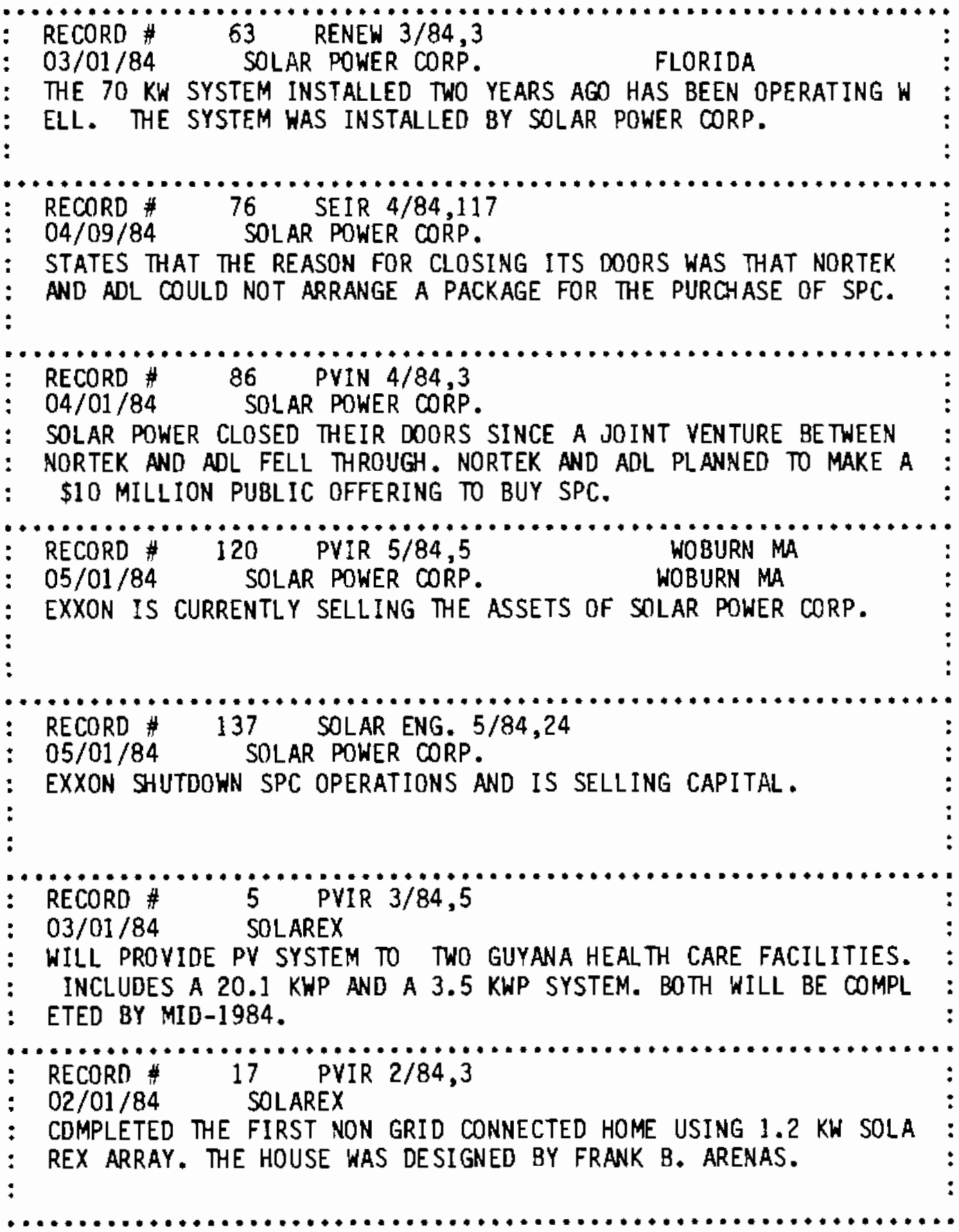




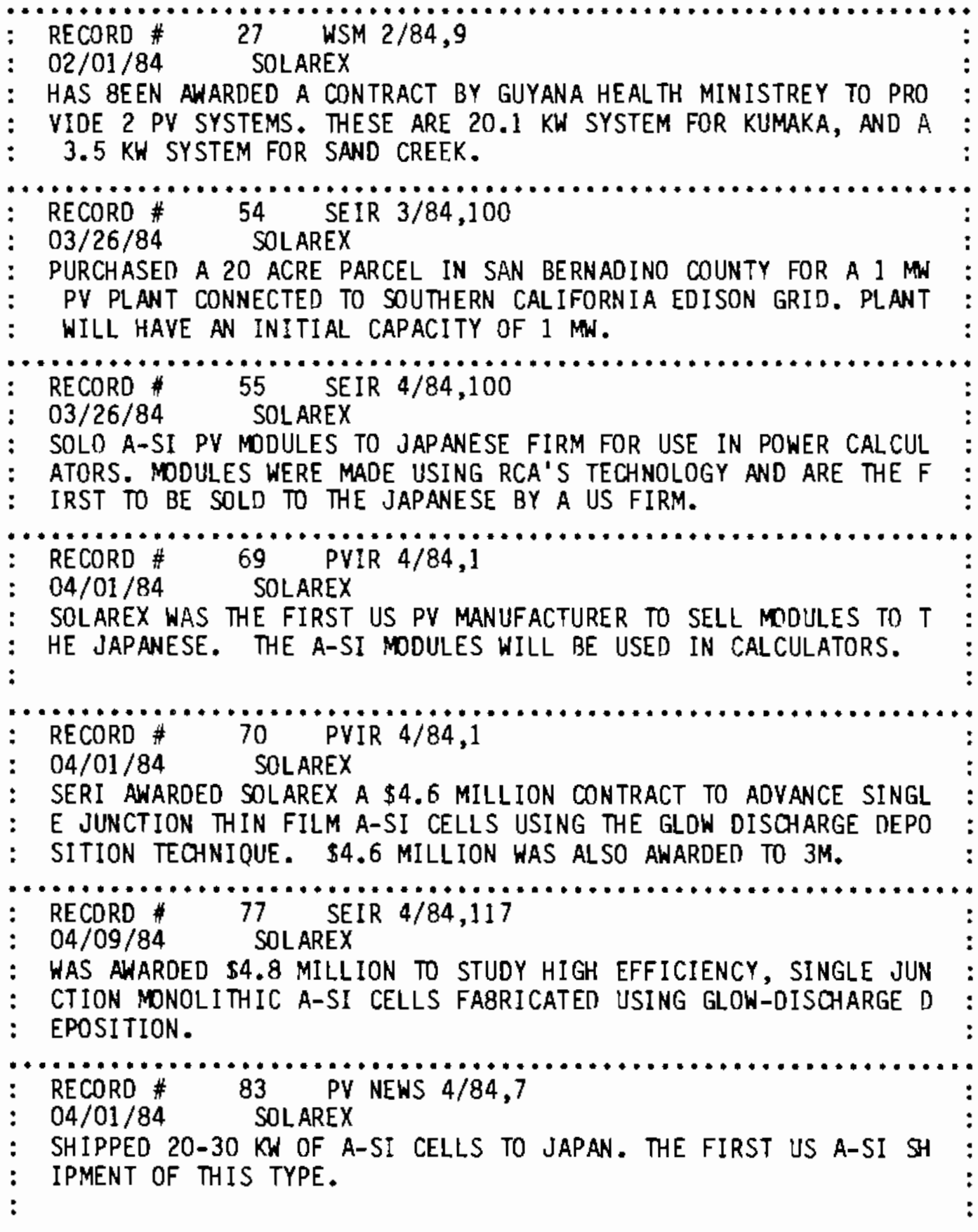




\section{PV EVENTS}

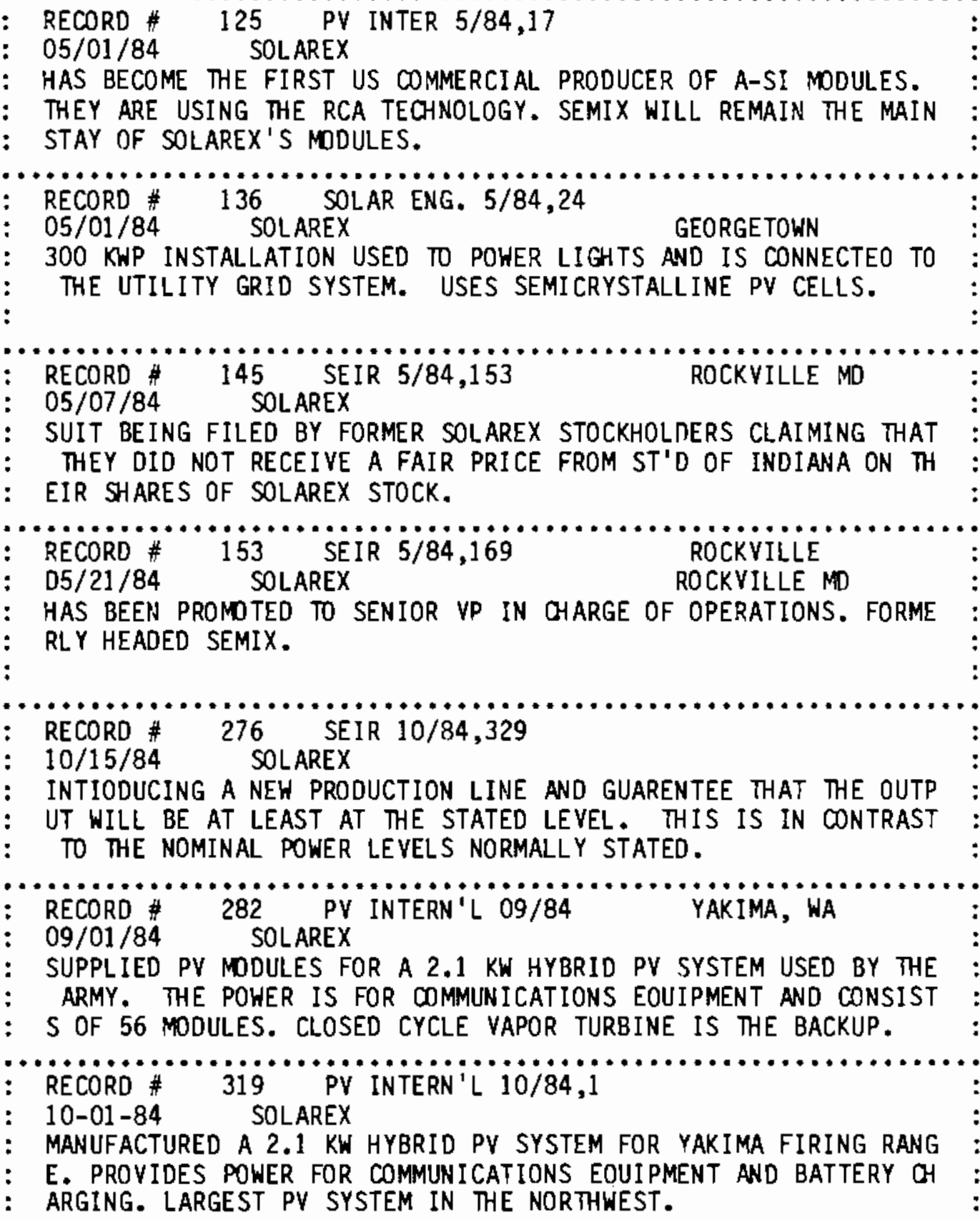




\begin{tabular}{|c|}
\hline $\begin{array}{l}\text { RECORD \# } 362 \text { SEIR } 12 / 84,405 \\
12-24-84 \text { SOLAREX } \\
\text { SELLING THEIR MARTINSBURG SILICON PURIFICATION PLANT BECAIISE } \\
\text { OF THE SLOW GROWTH IN PV ANO TECH. PROBLEMS. NO FIRM OFFERS H } \\
\text { AVE BEEN RECEIVED TO DATE. }\end{array}$ \\
\hline $\begin{array}{l}\text { RECORD } \\
\text { D8 } / 01 / 84 \\
\text { REDUCED THEIR STAFF } 8 Y \text { SY } 70 \text { PEOPLE INCLUDING MANAGERS OF RESEAR } \\
\text { CH, ENGINEERING, AND MANUFACTURING. }\end{array}$ \\
\hline $\begin{array}{l}\text { RECORD } \\
\text { O6/01/84 } 194 \text { SOLAREX CORP. } \\
\text { ANNOUNCED THAT THE FINAL MDDULES WERE SHIPPED FOR A LARGE GEO } \\
\text { RGETOWN UNIVERSITY PROJECT. }\end{array}$ \\
\hline $\begin{array}{l}\text { RECORD } \quad 218 \text { SEIR } 8 / 84,260 \\
\text { O8/13/84 } \\
\text { REDUCED THEIR SOLAREX CORP. } \\
\text { ANY STILL HAS OVER } 500 \text { EMPLOYEES AND VERY STRONG CUSTOMERS. }\end{array}$ \\
\hline $\begin{array}{l}\text { RECORD } \\
\text { O9/01/84 } \\
\text { HAS COMPLETED AN AMBITIOUS PROGRAM TO COMMERCIALIZE THEIR A-S } \\
\text { I CELLS. THEY ESTABLISHED THEIR THIN FILM DIVISION IN NEWTON } \\
\text { PA. AND ARE THE FIRST US FIRM TO MANFACTURE AND SELL A-SI. }\end{array}$ \\
\hline $\begin{array}{l}\text { RECORD } \\
10 / 01 / 84 \\
\text { CAPTURED } \$ 1.44 \text { MILLIOREX CORP. } \\
\text { SITES AND MILITARY BACKPACKS. }\end{array}$ \\
\hline $\begin{array}{l}\text { RECORD } \$ 265 \text { SEIR } 09 / 84,302 \\
\text { O9/24/84 } 4 \text { SOLAREX CORP. } \\
\text { ANARED } \$ 1.44 \text { MILLION FROM EGYPT TO FOR REMOTE TELECOMMUNICATI } \\
\text { ONS EQUIPMENT AND MILITARY BACKPACKS. }\end{array}$ \\
\hline
\end{tabular}


1984 PV EVENTS

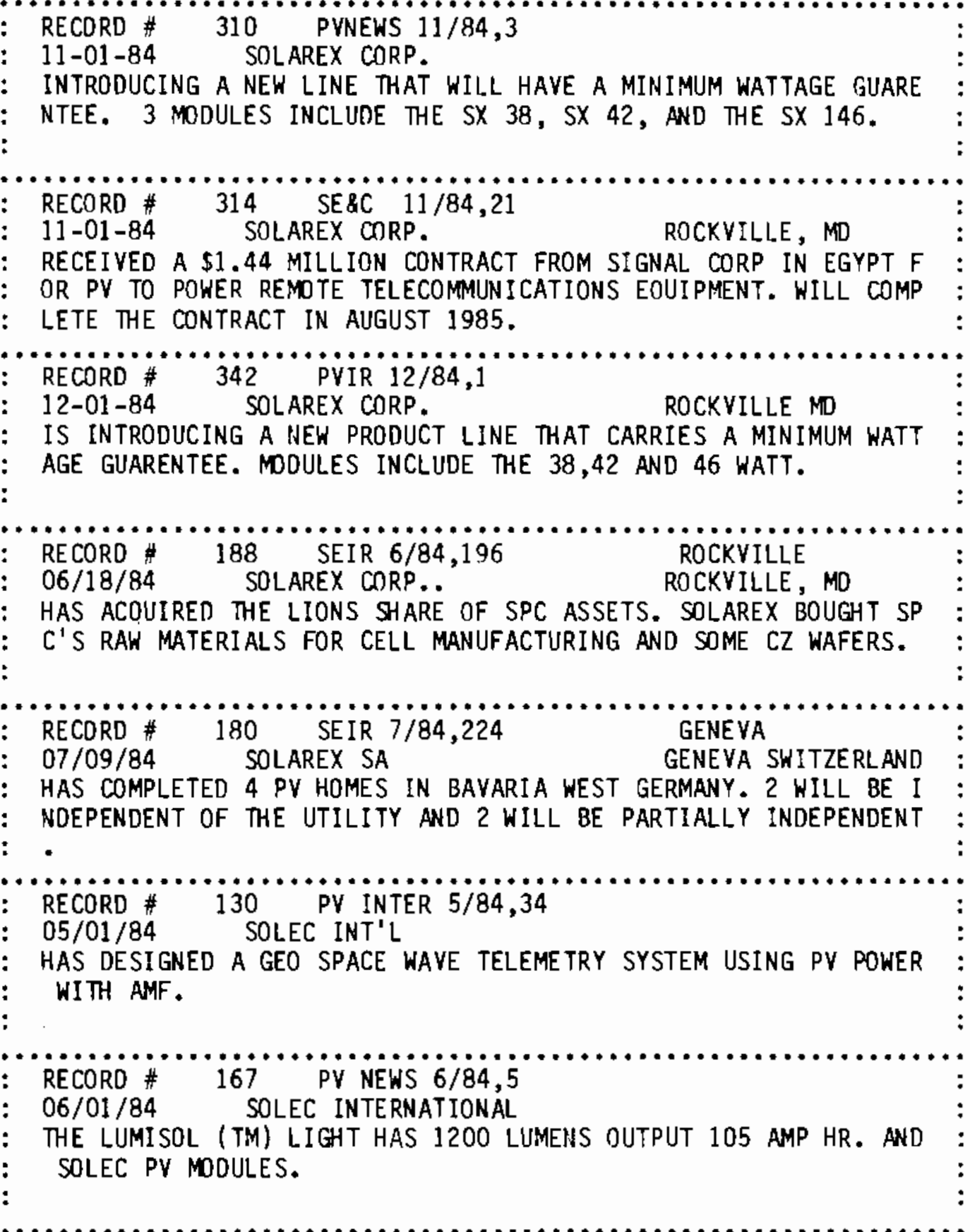


1984 PV EVENTS

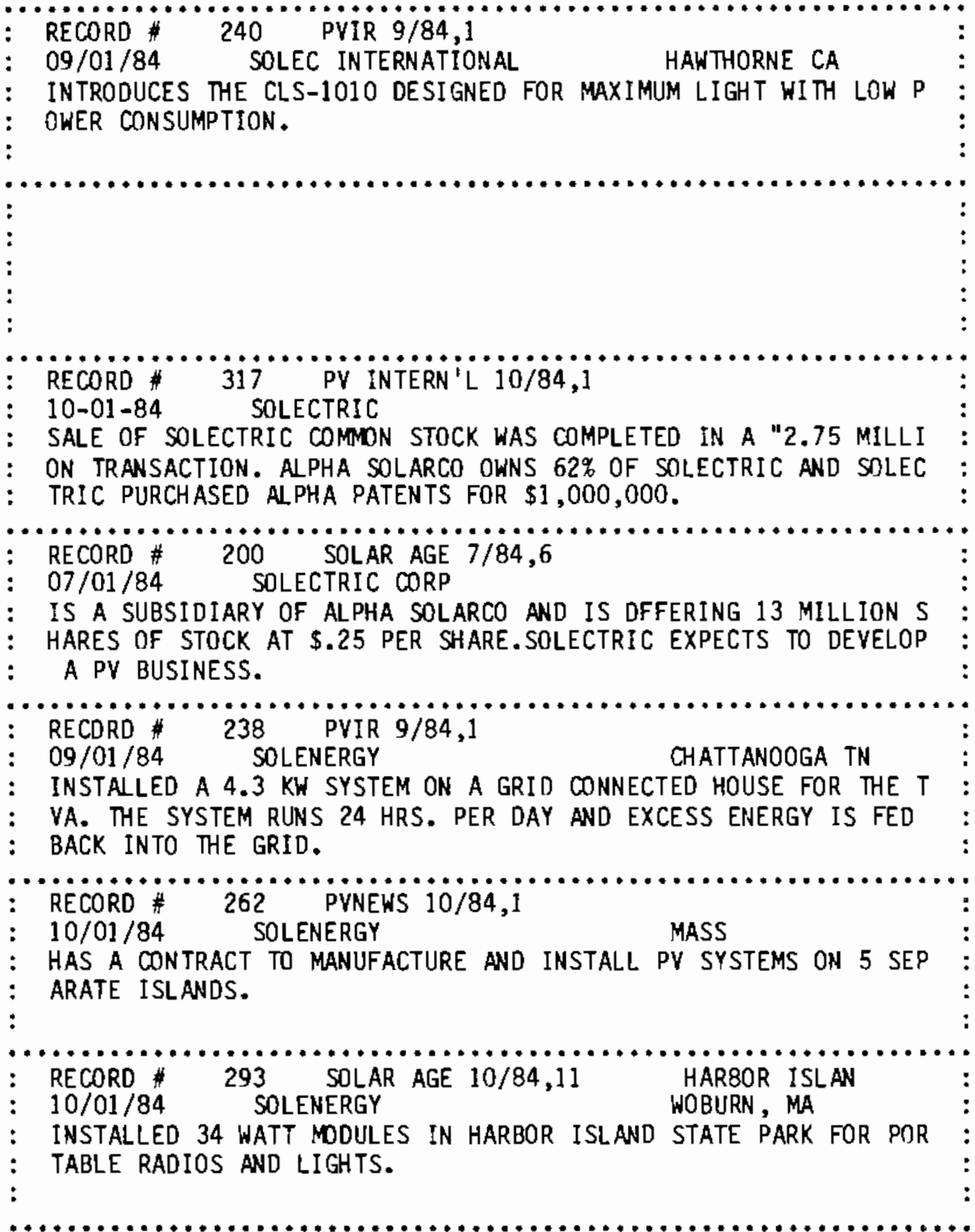




\section{PV EVENTS}

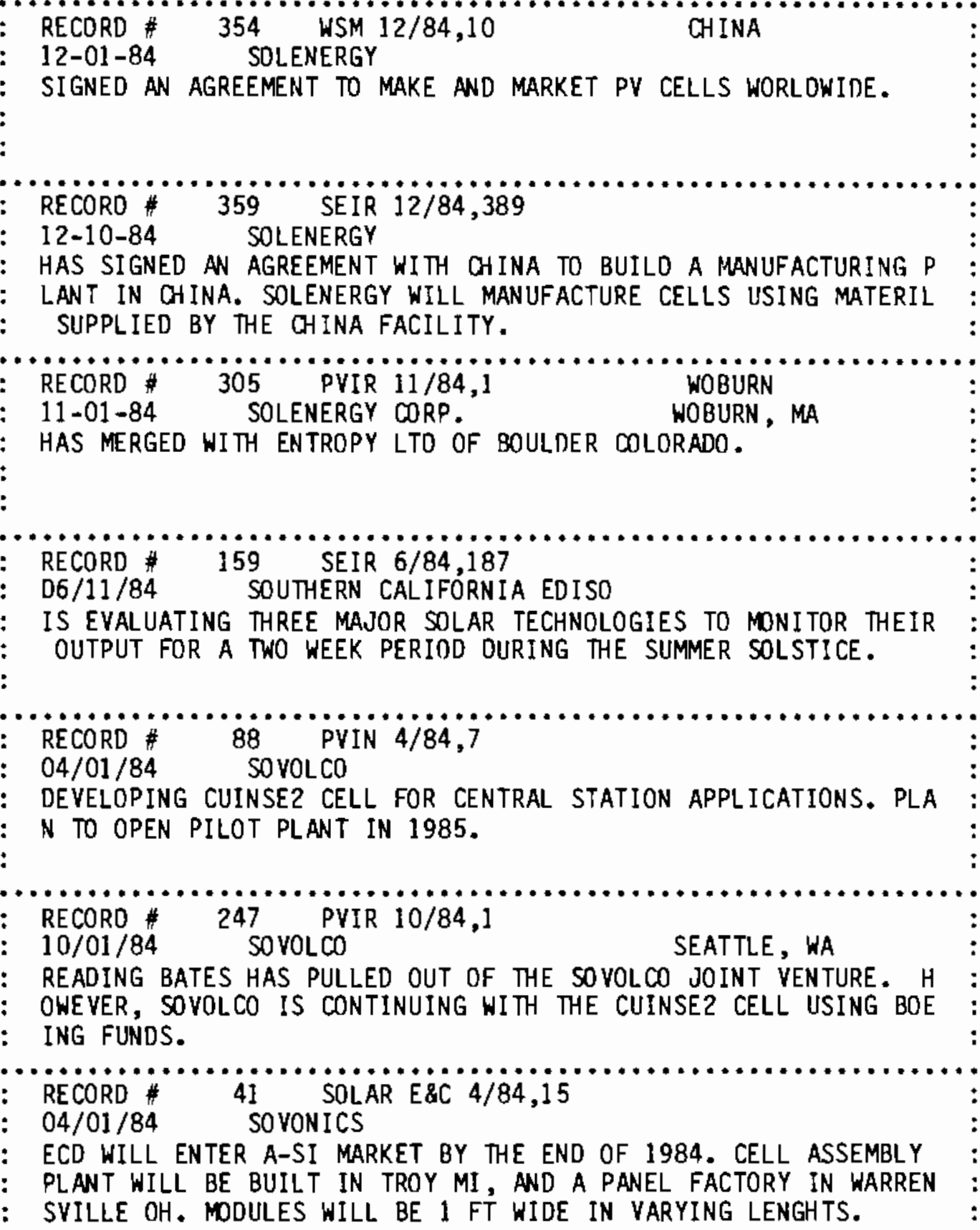


1984 PV EVENTS

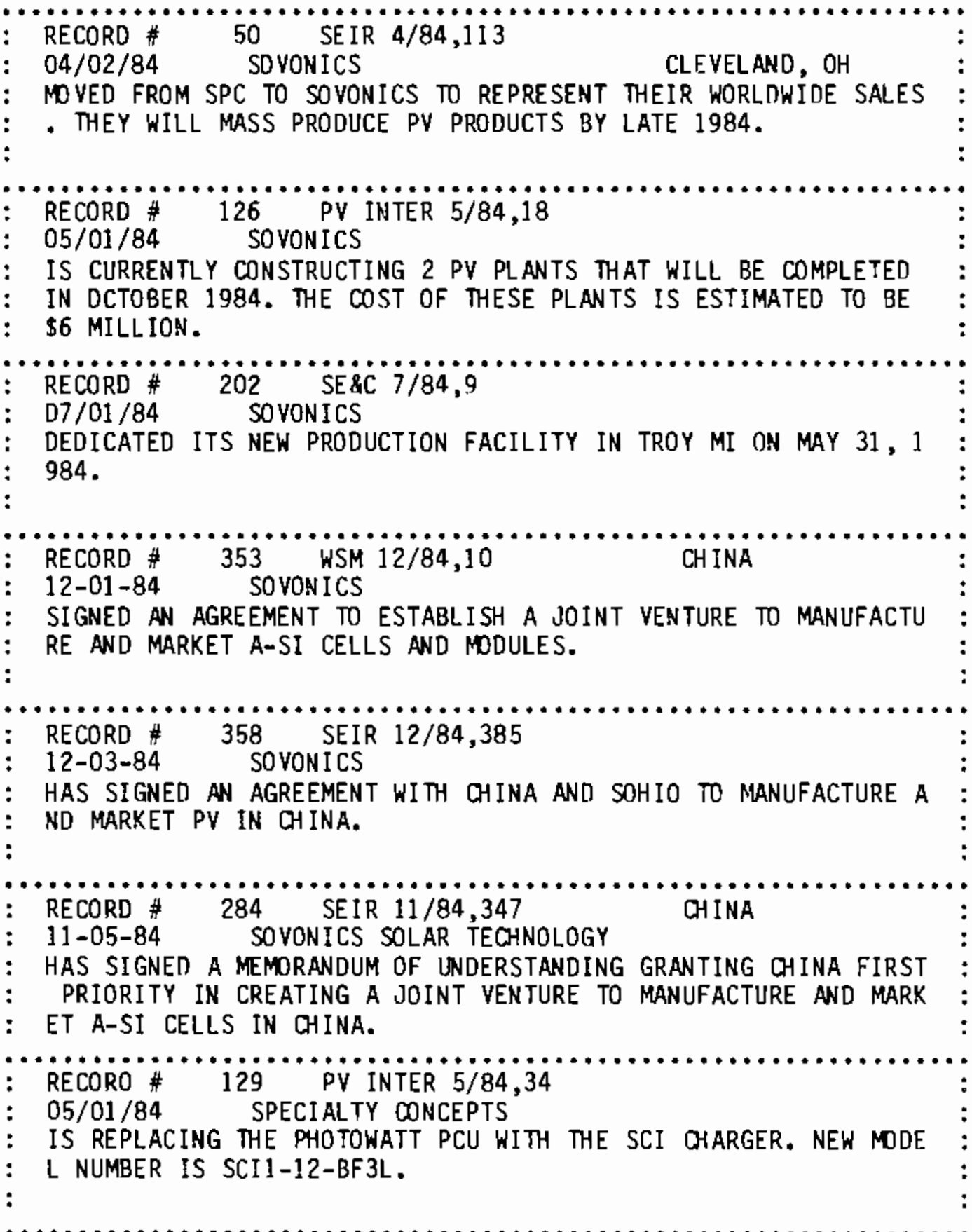




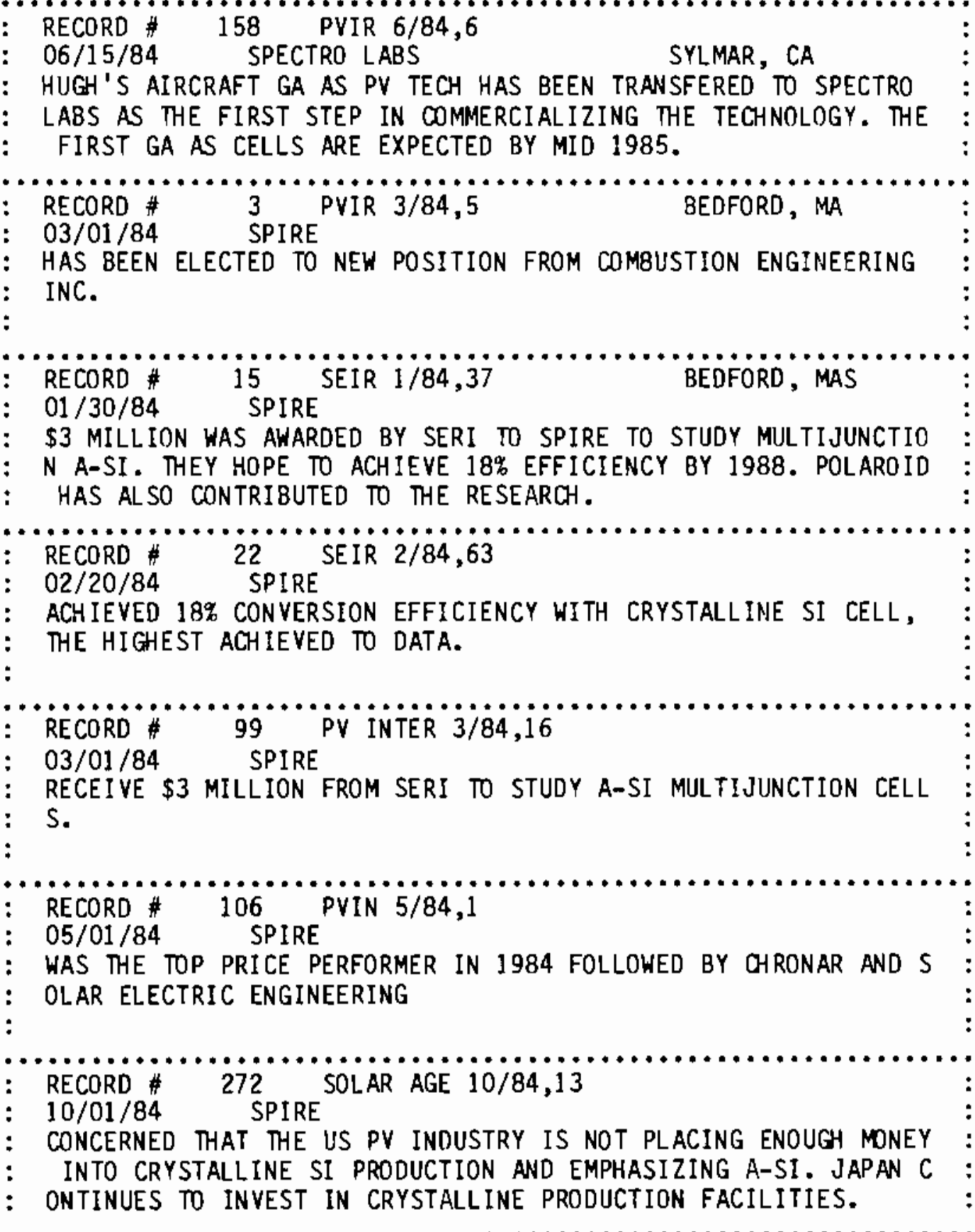




\section{PV EVENTS}

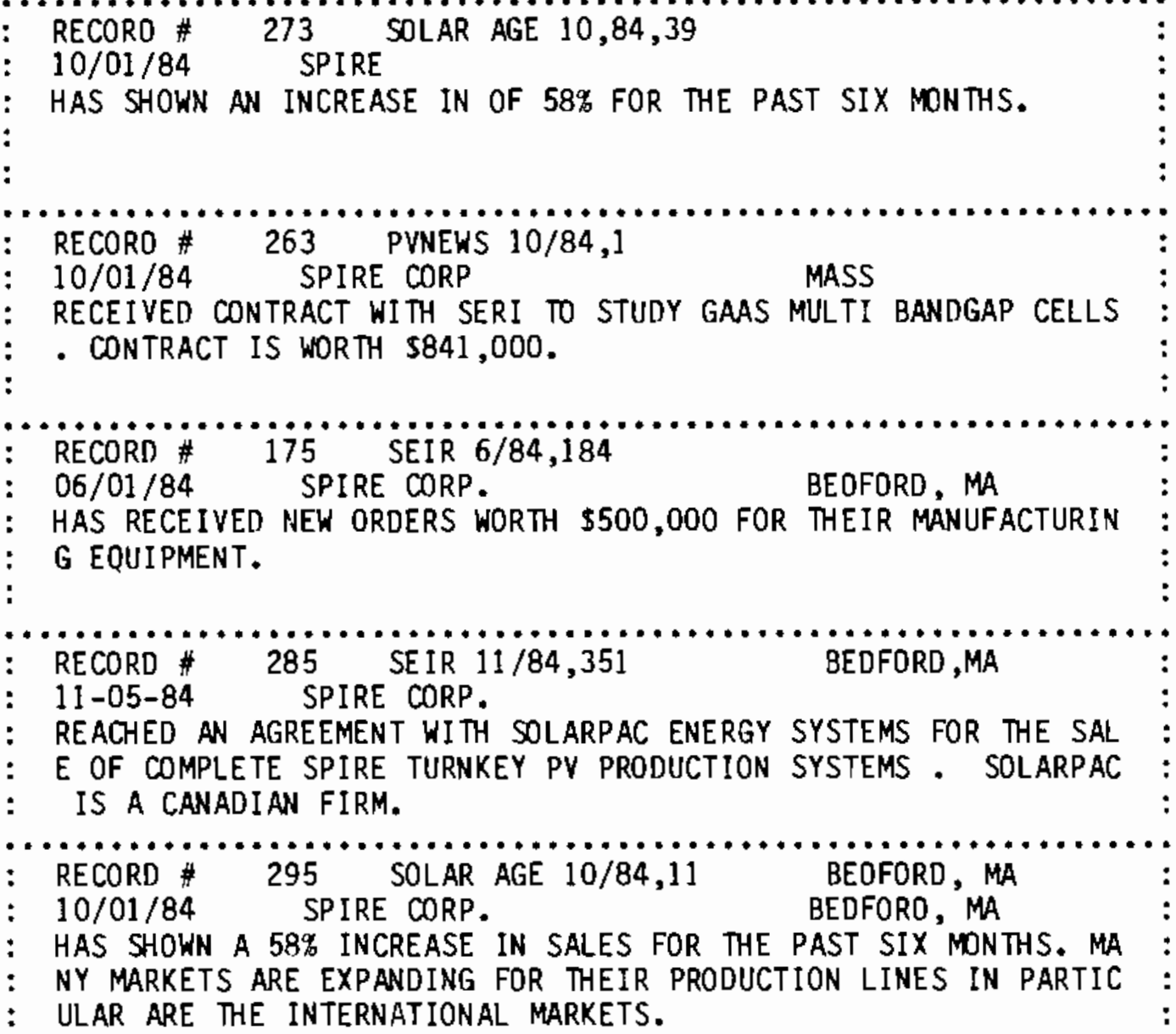

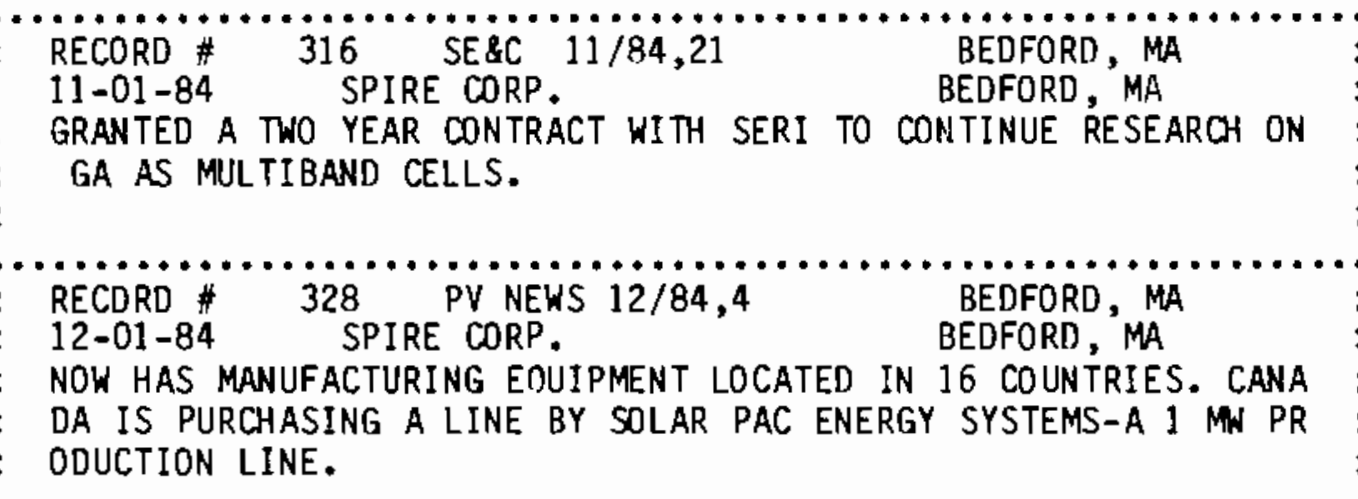




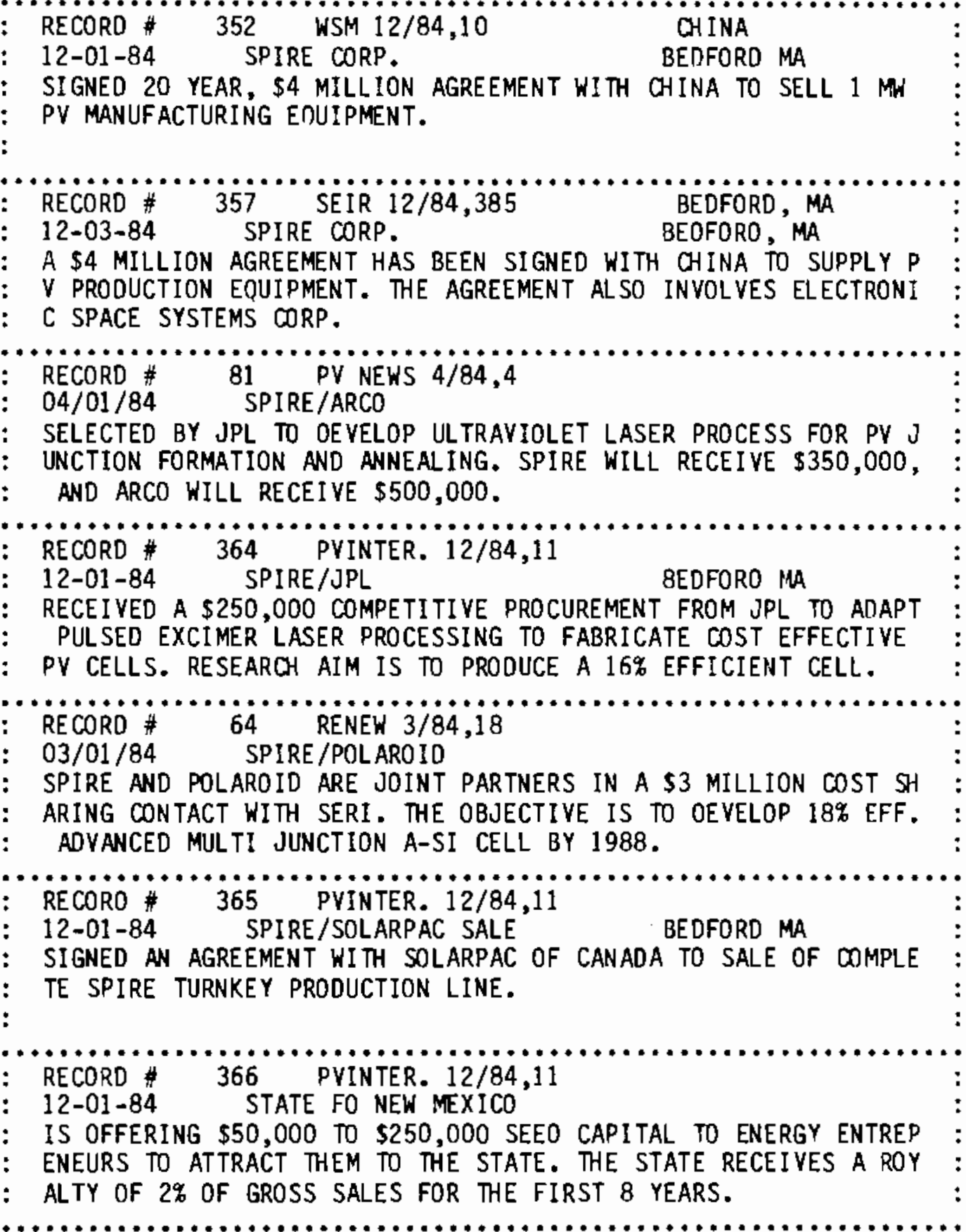




\section{PV EVENTS}

\begin{tabular}{|c|}
\hline $\begin{array}{l}\text { RECORD \# } \quad 24 \text { SEIR } 2 / 84,52 \\
\text { D2/13/84 STATE OF MASS. } \\
\text { HAS PLANS TO MAKE MASS THE NATION'S LEADER IN PHDTOVDLTAICS. } \\
\text { PLANS INCLUDE BUILDING LARGE PV DEMOS. EXPORT TRADING CO., F } \\
\text { IELD TESTING, CENTER OF EXCELLENCE, \& PARTNERSHIPS. }\end{array}$ \\
\hline 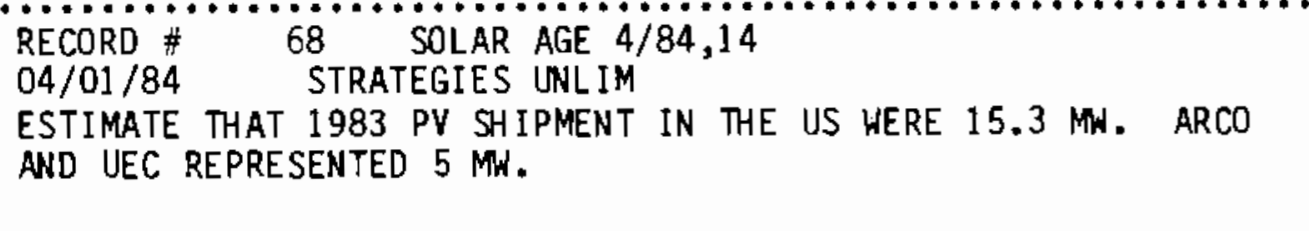 \\
\hline $\begin{array}{l}\text { RECORD } \# \text { } 241 \text { PVIR } 9 / 84,1 \\
\text { O9/01 } / 84 \text { SUMAMP } \\
\text { HAS AN ELECTRONIC BOAT KIT FOR FISHERMAN THAT INCLUDES AN 16- } \\
200035 \text { WATT MDDULE, DEEP CYCLE BATTERY, VOLTAGE REGULATOR. }\end{array}$ \\
\hline $\begin{array}{l}\text { RECORD } \\
04 / 30 / 84 \\
\text { HAS DEVELOPED A PRDCESS FOR RECOVERING GALLIUM FROM BALIXITE. } \\
\text { GA IS REFINED TO 5N PURITY. }\end{array}$ \\
\hline $\begin{array}{lll}\text { RECORD } \# & 111 \text { PVIN } 5 / 84,4 & \text { JAPAN } \\
\text { 05/01/84 SUNSHINE PROJECT } & \text { JAPAN } \\
\text { INCREASED PV FUNDING FRDM } \$ 23.54 \text { MILLION IN } 1983 \text { TO } \$ 30.54 \mathrm{MI} \\
\text { LLION IN } 1984 .\end{array}$ \\
\hline $\begin{array}{lll}\mathrm{RECORD} \# \\
\mathrm{D} 3 / 01 / 84\end{array}$ \\
\hline $\begin{array}{l}\text { HAS SIGNED AN AGREEMENT WITH PILIPINAS SUNPOWER INDUSTRIES AN } \\
\text { D DEVELOPMENT CORP TO ESTABLISH THE PV INDUSTRY IN THE PHILIP } \\
\text { PINES. }\end{array}$ \\
\hline $\begin{array}{l}\text { RECDRD \# } 324 \text { PV INTERN'L } 10 / 84,1 \\
10-01-84 \quad \text { SUNWATT CORP. } \\
\text { IS NOW OFFERING A SMALL BATTERY CHARGER FOR } \$ 24.00 \text {. CAN CHARG } \\
\text { E EITHER AA ,C OR D BATTERIES. }\end{array}$ \\
\hline
\end{tabular}


1984 PV EVENTS

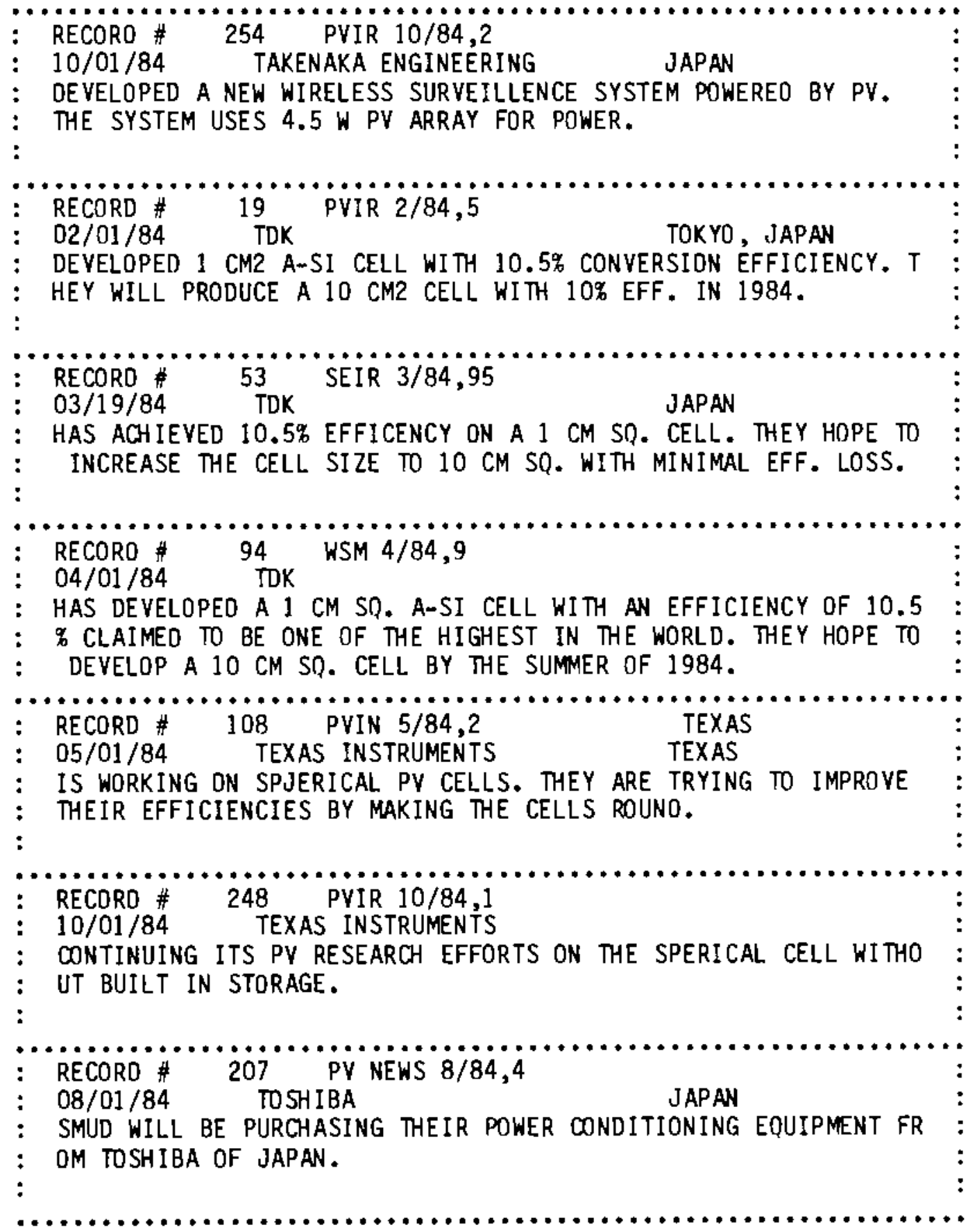




\section{PV EVENTS}

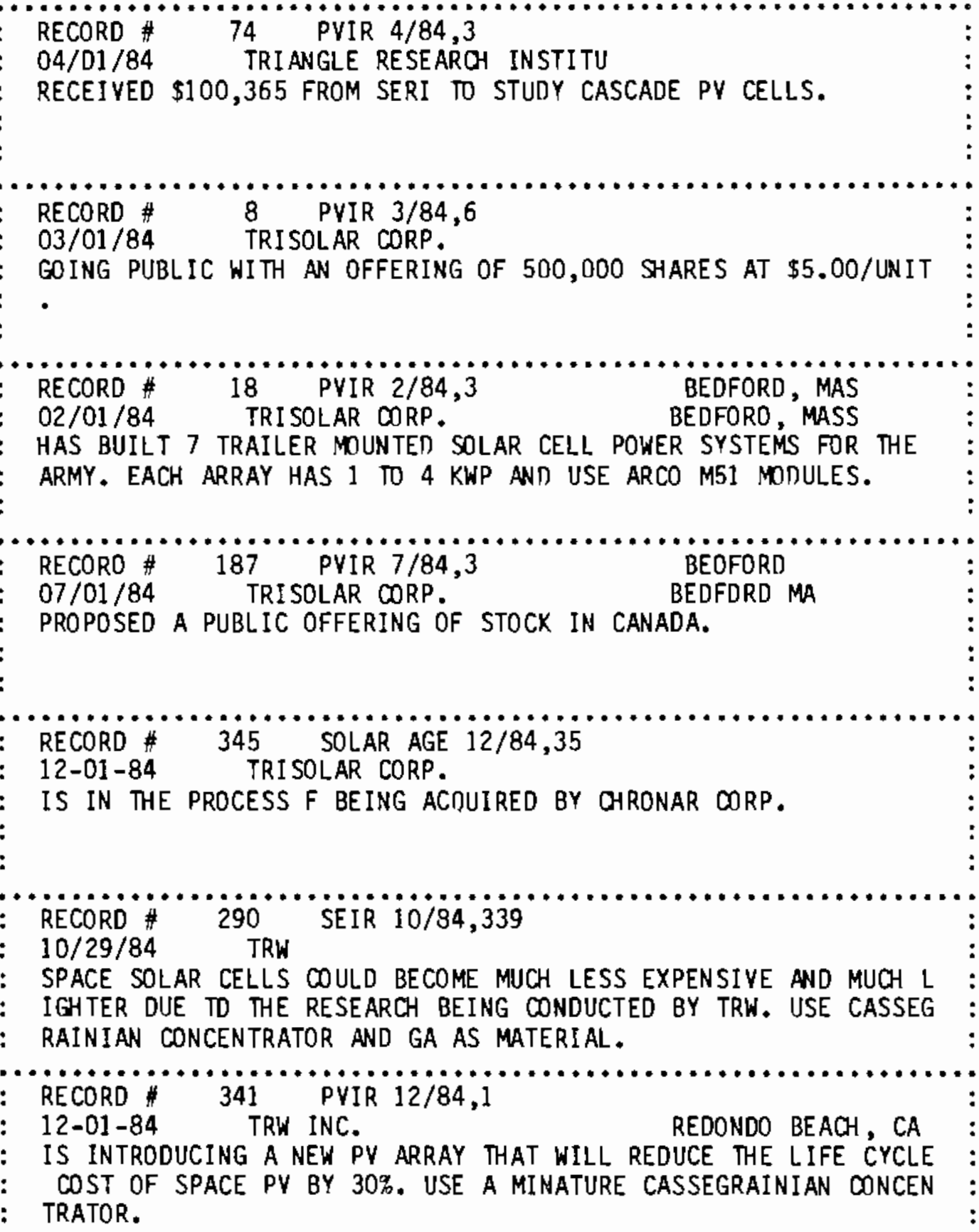




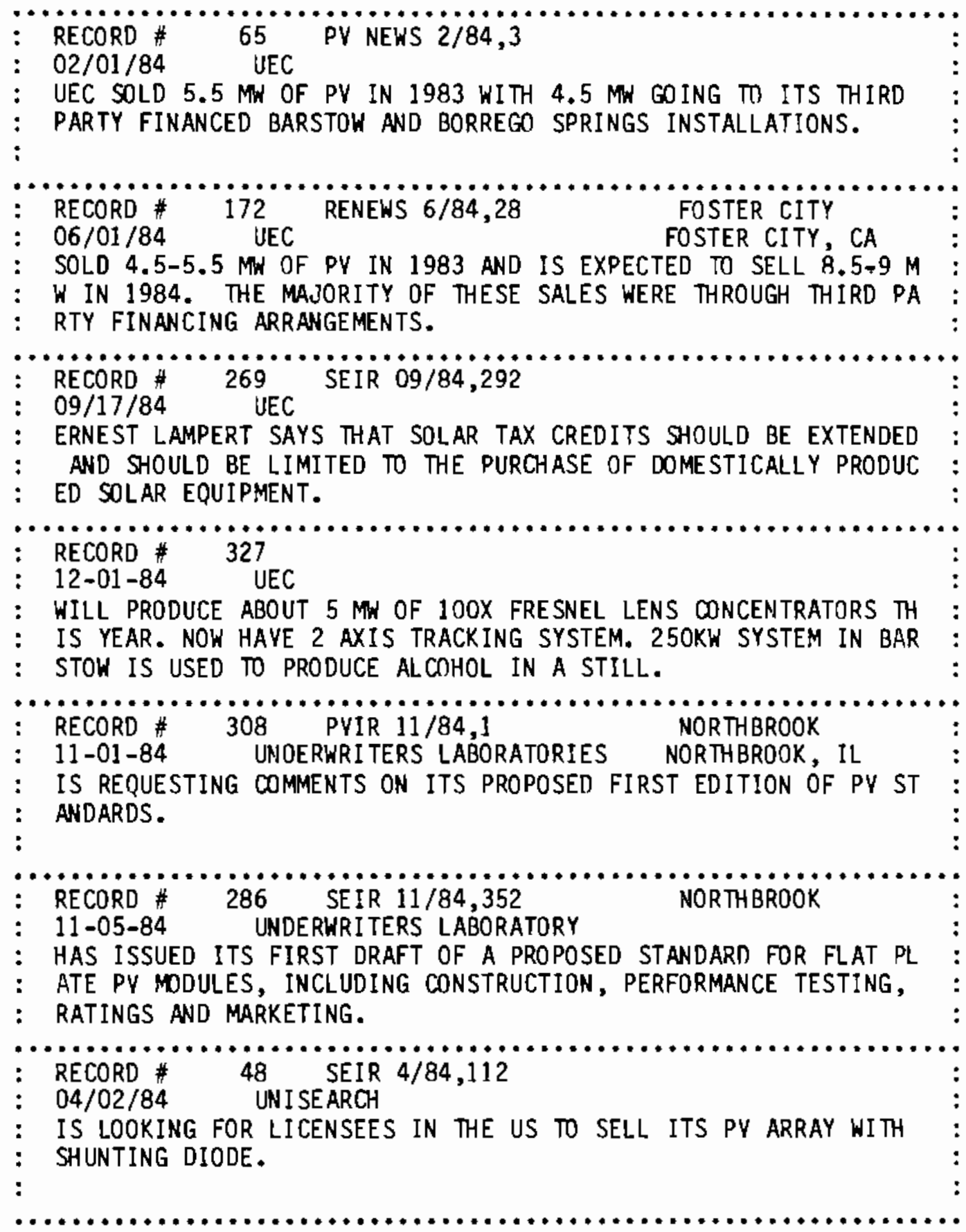


DATE LISTED 03-08-85

1984 PV EVENTS

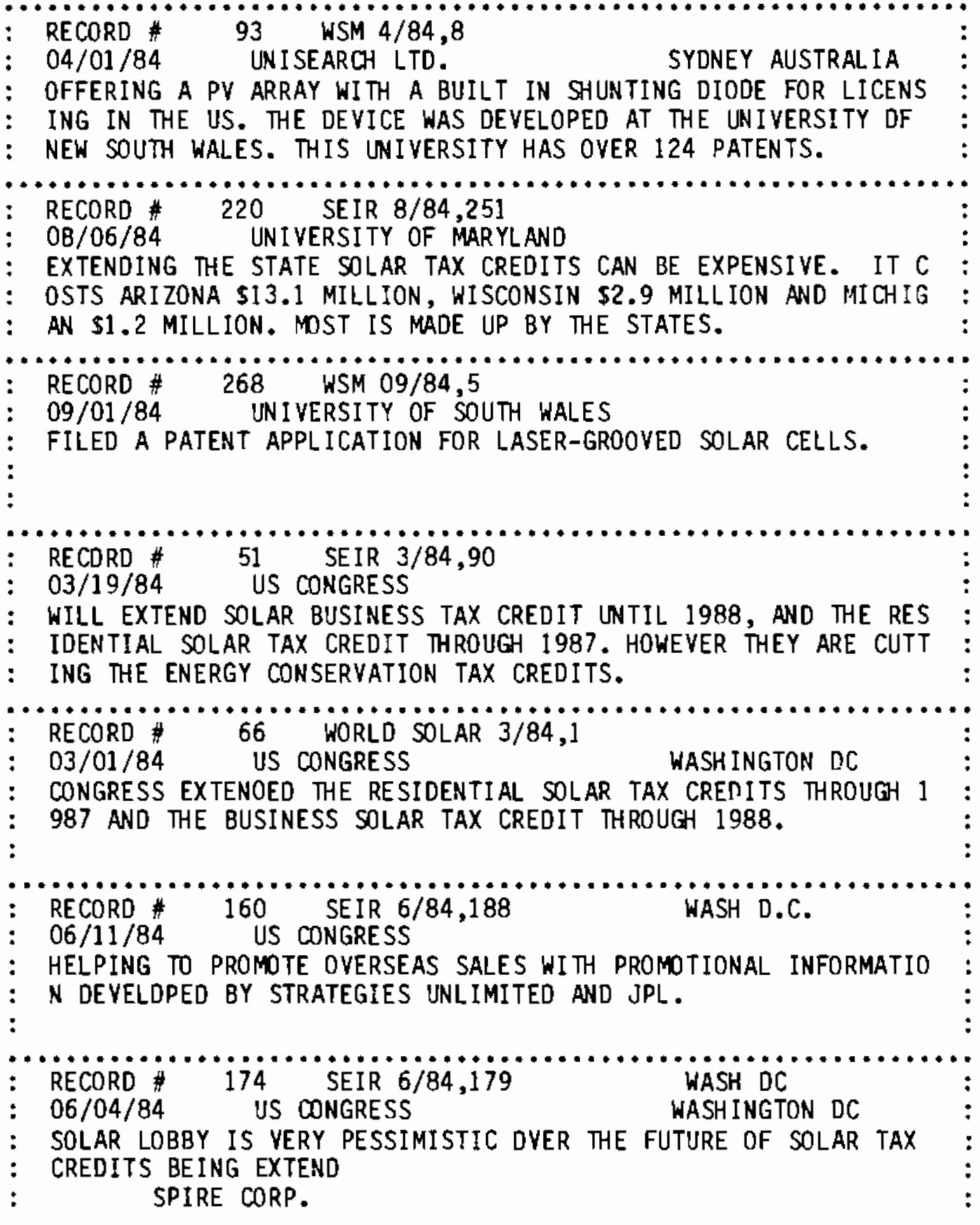




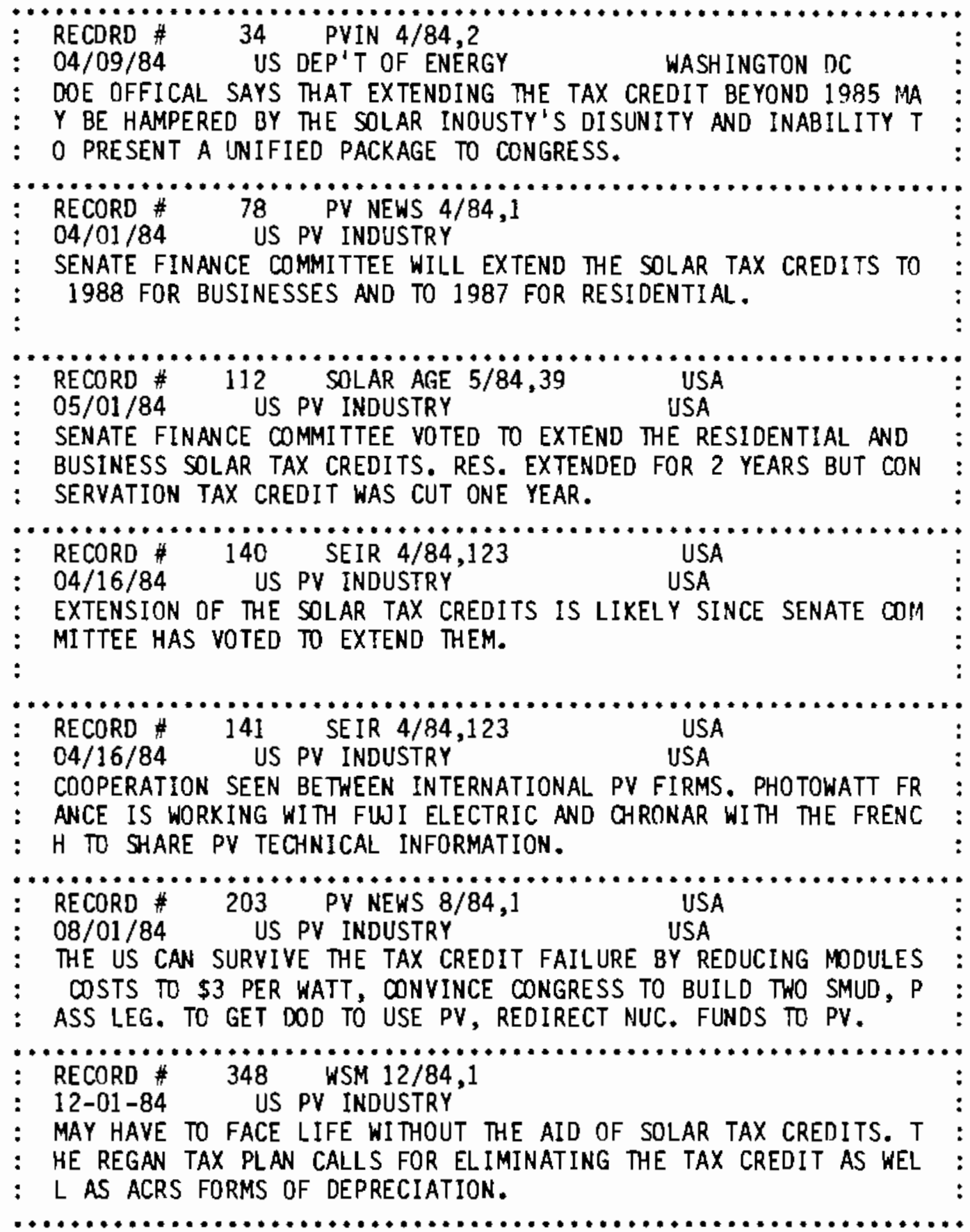


DATE LISTED 03-08-85

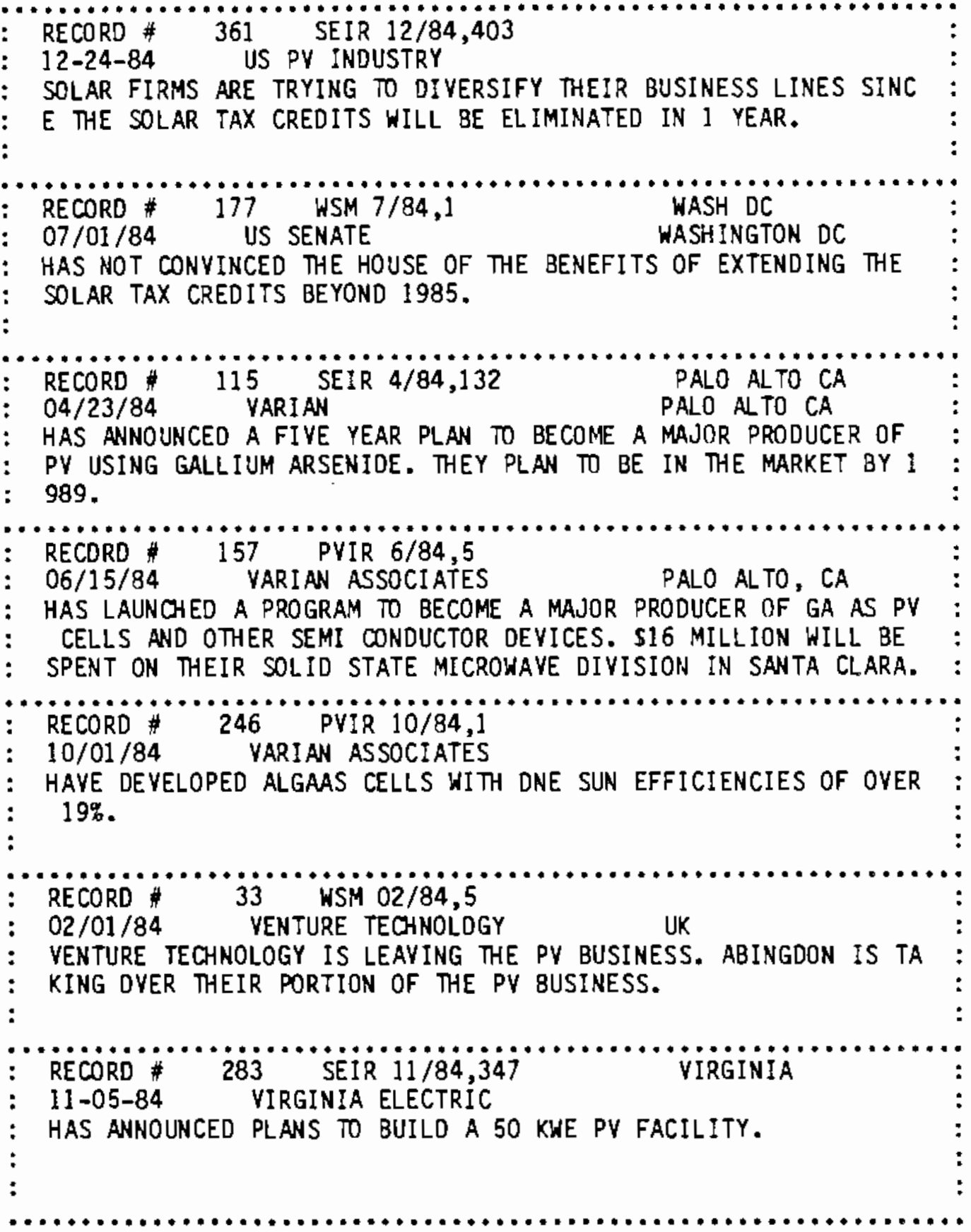




\section{PV EVENTS}

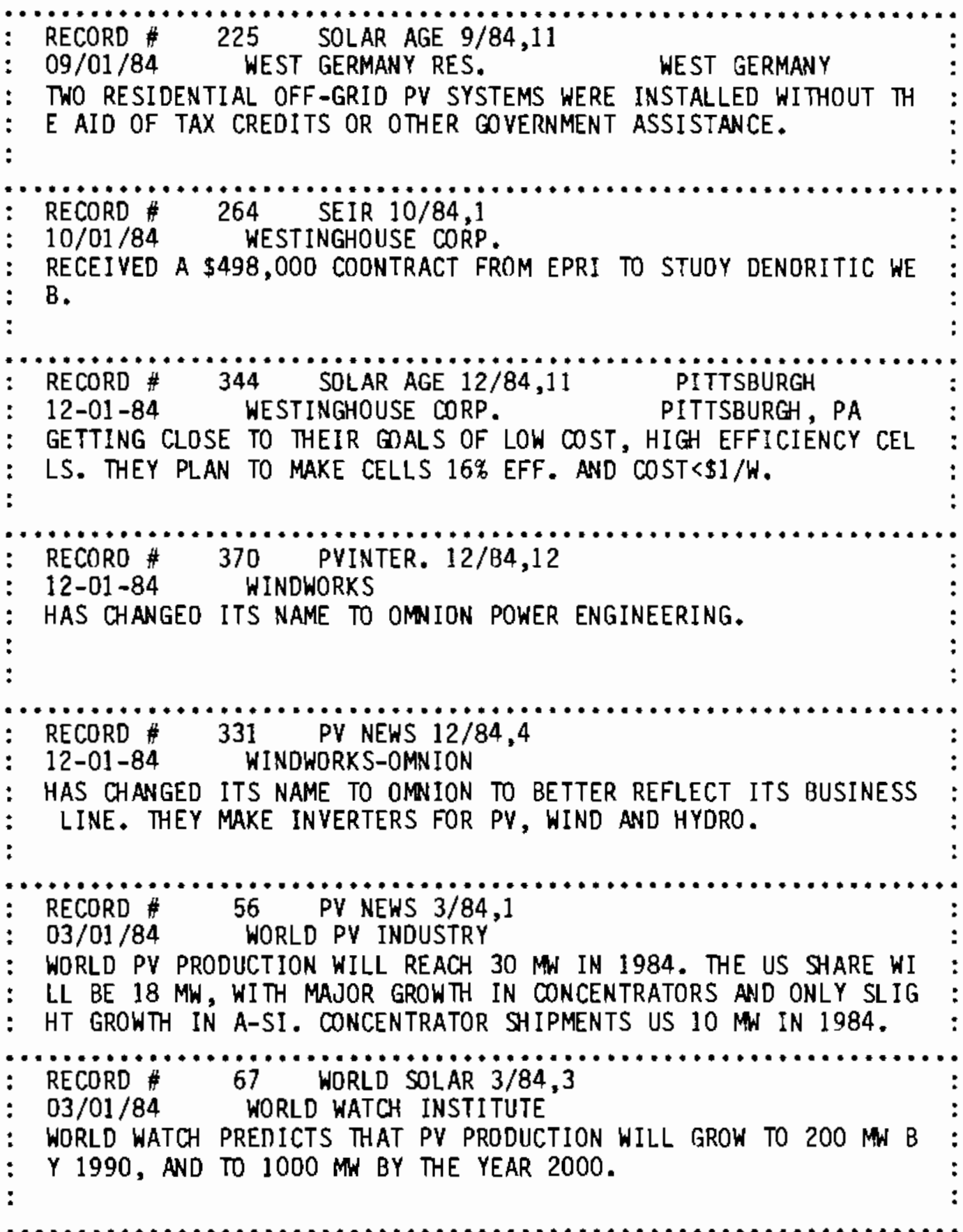


5

Y 
No. of

Copies

OFFSITE

30 DOE Technical Information

Bud Annan

Photovoltaic Energy Technology

Division

Department of Energy

$600 \mathrm{E}$. Street, MW

Washington, DC 20585

25 Andrew Krantz

Department of Energy

Forrestal Building

Washington, OC 20585

Or. Morton B. Prince

Department of Energy

Forrestal Building

Washington, DC 20585

Vincent Rice

Department of Energy

Forrestal Building

Washington, DC 20585

Peter Glaser

Arthur D. Little, Inc.

Acorn Park

Cambridge, Mass 02140

Jack Dodd

OMB Room 8002

New Executive Office Building

726 jackson Place, NW

Washington, DC 20503

H. Richard Blieden

Energy Conversion Devices

1675 West Maple Road

Troy. MI 48084

George D. Self

Chronar

PO Box 177

Princeton, Nu 08540
No. of

Copies

Roger Little

Spire Corporation

Patriots Park

Bedford, MA 01730

Robert Willis

Solenergy Corp.

171 Merrimac Street

Woburn, MA 01801

Bob Kaufman

ARCO Solar

20554 Plummer Street

Chatsworth, CA 91311

Mac Ream

Solarex Corporation

1335 Piccard Drive

Rockville, MO 20850

Harry J. Saenger

Tideland Signal Corp.

4310 Directors Row

Box 52430

Houston, TX 77052

Bob Hamstond

Mobil Solar Energy Corp.

16 Hickory Drive

waltham, MA 02254

Ernie Lampert

United Energy Corp.

420 Lincoln Center Drive

Foster City, CA 94404

Ishaq Sharayer

Solec International

12533 Chadron Street

Hawthorne, CA 90250

Bill O'Connor

Solavolt International

P0 Box 2934

Phoenix, AZ 85062

Paul Maycock

Photovoltaic Energy Systems, Inc. 2401 Childs Lane

Alexandria, VA 22308 
No. of

Copies

ONSITE

DOE Richland Operations Office

HE Ransom/DR Segna

71 Pacific Northwest Laboratory

$\mathrm{CH}$ Bloomster

JA Dirks (5)

RM Fleischman

RP Mazzucchi

SA Smith (5)

RL Watts (48)

Economics Library (3)

Technical Information (5)

Publishing Coordination (2) 